GERALDO HENRIQUE DE SOUZA ARMOND

\title{
A RESPONSABILIDADE OBJETIVA DO EMPREGADOR NO ACIDENTE DO TRABALHO
}

\author{
DissertaÇão de Mestrado \\ Orientador: Prof. Dr. Ari Possidonio Beltran
}

FACULDADE DE DIREITO DA USP

SÃO PAULO

2011 


\section{GERALDO HENRIQUE DE SOUZA ARMOND}

\section{A RESPONSABILIDADE OBJETIVA DO EMPREGADOR NO ACIDENTE DO TRABALHO}

Dissertação de Mestrado apresentada à Banca Examinadora da Faculdade de Direito da Universidade de São Paulo, como exigência parcial para a obtenção do título de Mestre em Direito, sob orientação do Prof. Dr. Ari Possidonio Beltran.

FACULDADE DE DIREITO DA USP

SÃO PAULO

2011 
Banca Examinadora 


\section{AGRADECIMENTOS}

A Deus, pela experiência.

Aos meus pais, pelo apoio incondicional.

Ao Giovanni, meu filho, pela paciência.

Ao Professor Ari Possidonio Beltran, pela generosidade e tolerância.

Aos meus amigos, pelo incentivo. 


\section{RESUMO}

O presente estudo aborda o acidente do trabalho e sua reparação pelo direito comum em face dos dois principais sistemas que fundamentam a responsabilização civil do empregador por acidentes do trabalho - subjetivo e objetivo -, principalmente após a entrada em vigor do novel Código Civil brasileiro, o qual, a despeito de ter mantido como regra geral, no caput do seu artigo 927, a responsabilidade subjetiva, estabeleceu, no parágrafo único desse mesmo dispositivo, concomitantemente, regime especial de responsabilidade objetiva nas hipóteses especificadas em lei ou na hipótese de a atividade normalmente desenvolvida pelo autor do dano implicar, por sua natureza, risco para os direitos de outrem. Se há a compreensão imediata da primeira parte do parágrafo único do artigo em comento, na segunda, as hipóteses de risco são dadas sob a forma de cláusula geral, cabendo ao intérprete a tarefa de preencher a lacuna legal. Essa é uma tarefa que deve ser executada à luz da Constituição Federal brasileira, que prevê, em seu artigo $7^{\circ}$, inciso XXVIII, a responsabilidade do empregador por culpa ou dolo. Assim, na questão acidente do trabalho, a presente tese demonstra que a teoria do risco tem avançado cada vez mais sobre o terreno da responsabilidade subjetiva, sem, contudo, ter transformado a responsabilidade objetiva em regra geral incidente a partir de simples avaliação circunstancial de um dano verificado na relação de trabalho. Concluiu-se que as atividades que justifiquem a aplicação de uma responsabilidade especial dependem, na análise do caso concreto, antes da apreciação do mérito, de uma decisão judicial de natureza declaratória nesse sentido, representando valioso instrumento para a reparação dos danos ocorridos em atividades de risco não capituladas em lei.

Palavras-chave: Acidente do trabalho. Responsabilidade civil subjetiva. Responsabilidade civil objetiva. Responsabilidade do empregador. Responsabilidade civil pelo risco da atividade. 


\section{ABSTRACT}

The present study is concerned with labor-related accidents and their reparations through the normal course of law, taking into consideration the two main systems on which the employer's civil liability is based - subjective and objective -, especially after the new Brazilian Civil Code came into force, which, in spite of the general rule of subjective liability being upheld in the caput of article 937, established in the single paragraph of this same article a special regimen of objective liability on the basis of hypotheses specified in law or on the hypothesis that the activity normally undertaken by the author of damages incurred implies by its very nature in risk to the rights of others. If the first part of the single paragraph of the article under discussion may be immediately comprehended, in the second part, the hypotheses are presented as a general rule, thus leaving the task of filling this legal interpretation gap in the hands of the person making the interpretation. This is a task which should be undertaken in the light of the Brazilian Federal Constitution, which, in article $7^{\text {th }}$ subparagraph XXVIII, recognizes the liability of the employer by blame or intention. Thus with regard to labor-related accidents, the present thesis demonstrates that the theory of risk has increasingly advanced into the territory of subjective liability, without however turning objective liability into a general prevailing rule when undertaking circumstantial assessment of damages incurred as a result of work. It is concluded that activities which justify the application of special liability depend, where a concrete case is analyzed and before final judgment is passed, on a judicial declaration for this, and this represents a valuable instrument for reparation of damages incurred in activities of risk not covered by the law.

Key-words: Labor-related accident. Subjective civil liability. Objective civil liability. Employer's liability. Civil liability due to occupational risk. 


\section{SUMÁRIO}

I. INTRODUÇÃO

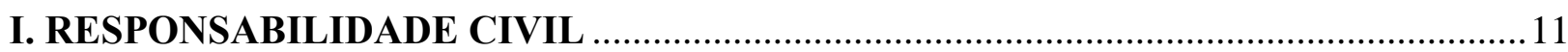

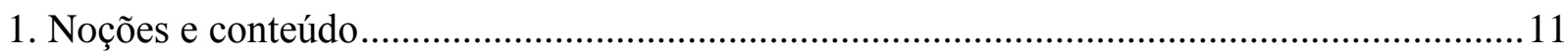

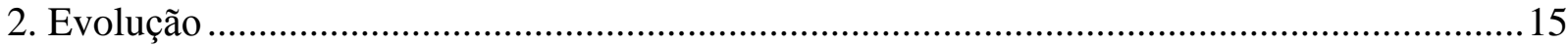

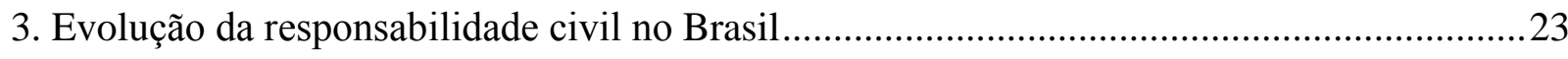

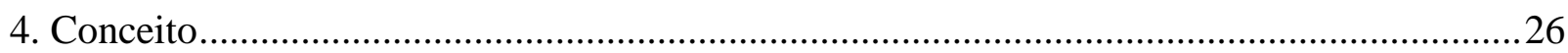

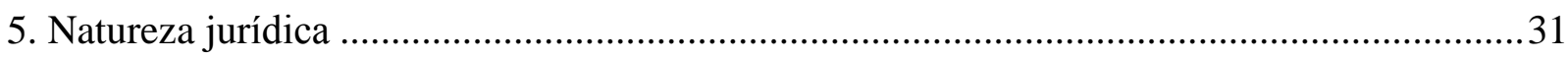

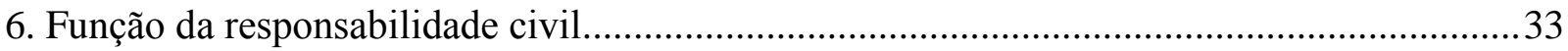

II. ESPÉCIES DE RESPONSABILIDADE CIVIL E TEORIAS APLICÁVEIS AO

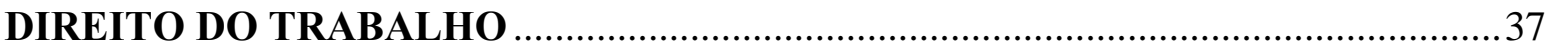

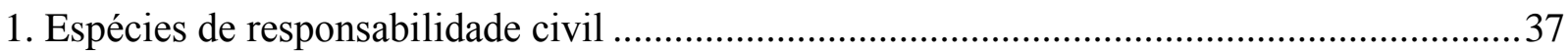

1.1. Responsabilidade contratual e responsabilidade extracontratual ................................37

1.2. Responsabilidade civil subjetiva e responsabilidade civil objetiva.............................39

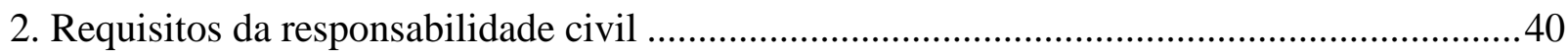

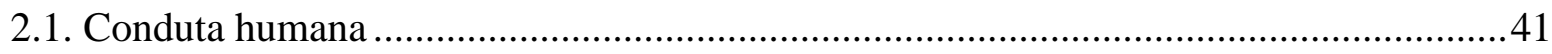

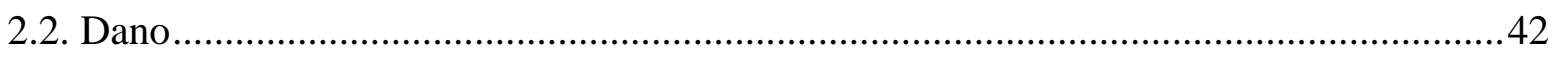

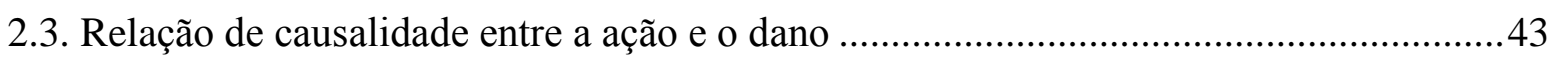

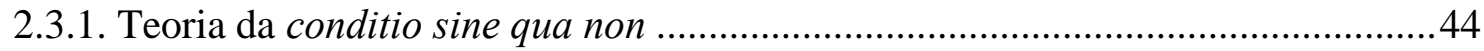

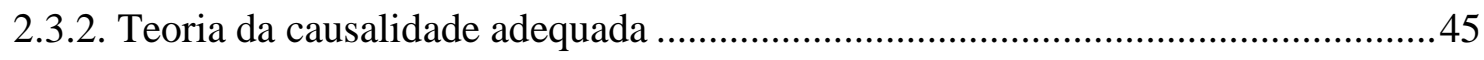

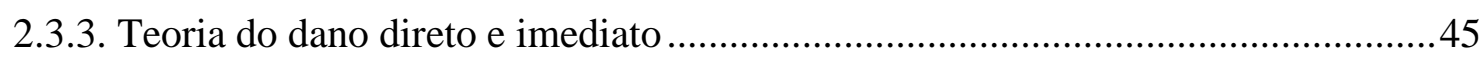

2.3.4. Teoria adotada pelo Código Civil brasileiro.....................................................45

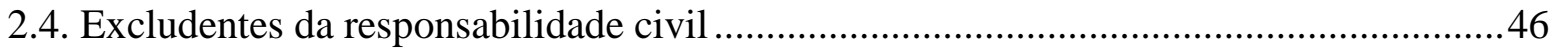

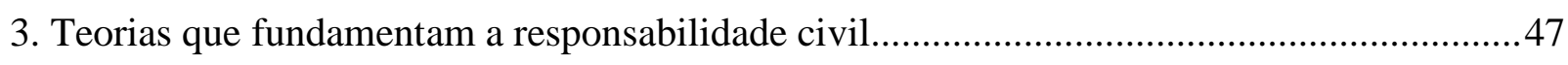

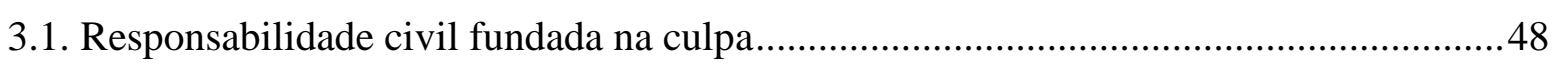

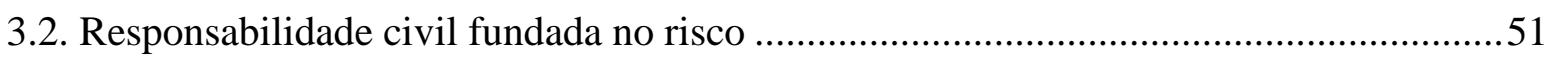

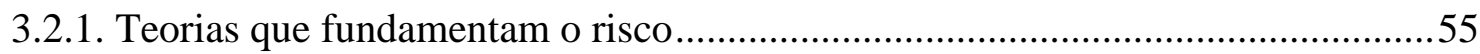

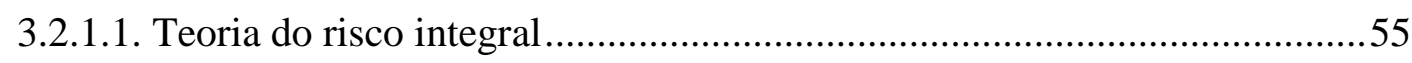

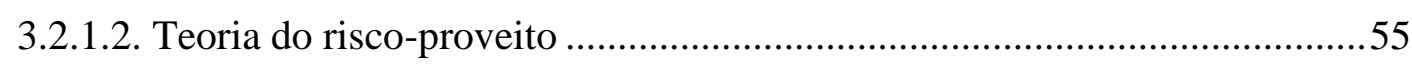

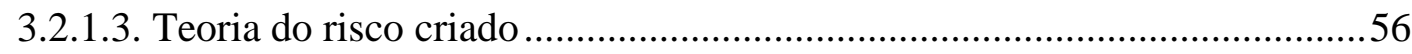

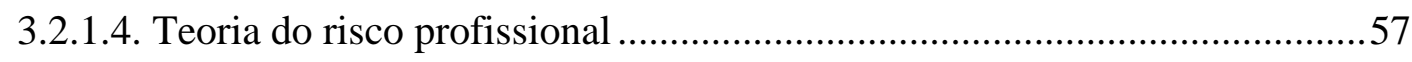

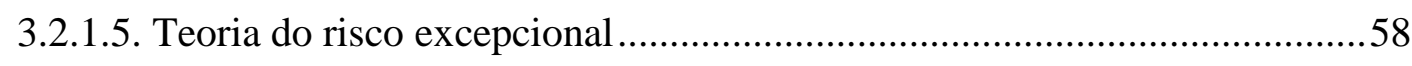

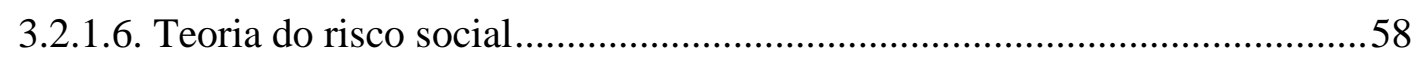

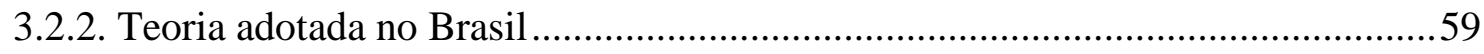


3.3. Evolução das teorias subjetiva e objetiva no direito brasileiro.....................................60

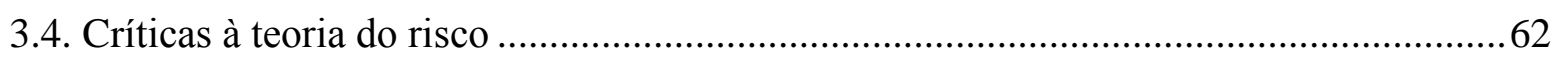

3.5. Atividade de risco e campo de aplicação da responsabilidade objetiva ........................63

III. RESPONSABILIDADE CIVIL POR ACIDENTE DO TRABALHO .........................69

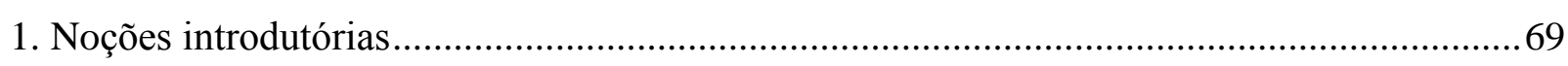

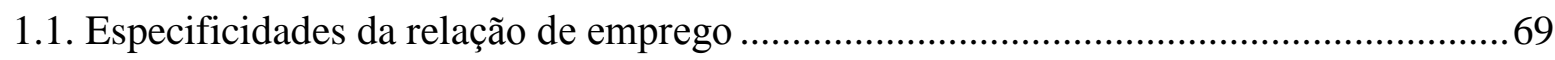

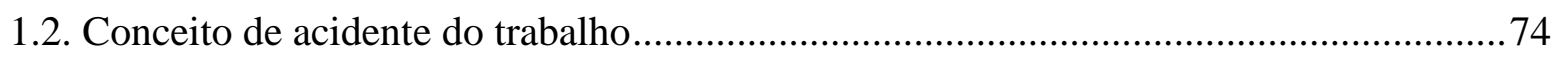

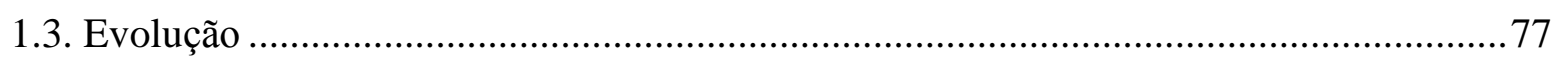

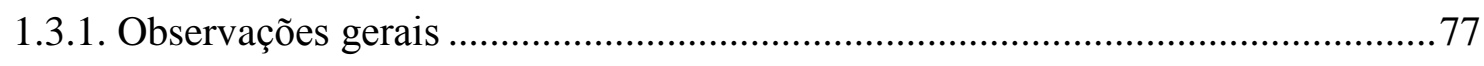

1.3.2. Evolução no Brasil - breve histórico ................................................................. 80

2. Teorias sobre a obrigação de reparar os danos decorrentes de acidentes do trabalho.............84

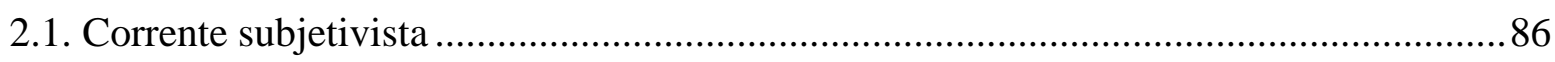

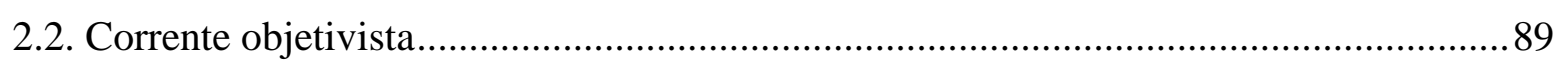

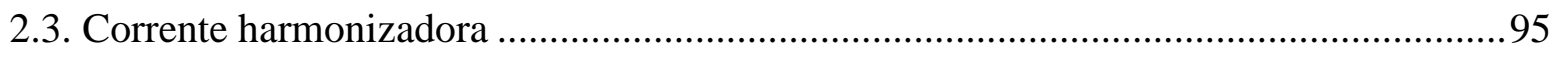

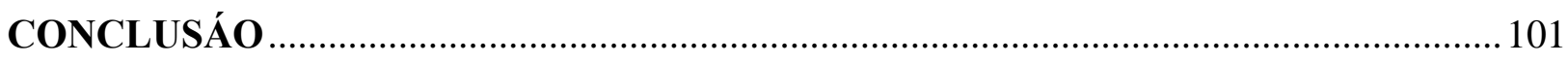

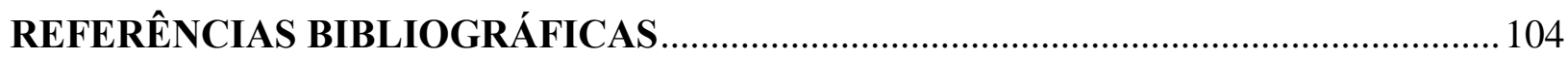




\section{INTRODUÇÃO}

O Direito Civil brasileiro registra, no momento atual, o rompimento com a clássica visão positivista. As fórmulas dadas e os sistemas tipificados, marcadamente frios e acríticos, são substituídos por conceitos abertos, regidos por princípios e valores eleitos fundamentais pela sociedade, como forma de extrair-se a máxima eficácia dos direitos positivados. Assim, os atores sociais deixam de ser meros objetos da lei, e todos são chamados a participar ativamente do processo civilizatório, exigindo-se comportamento alinhado com essa nova perspectiva do ordenamento legal.

Assim, o Código Civil de 2002 utiliza a técnica de cláusulas gerais e de conceitos jurídicos indeterminados, servindo de referência para materialização dos direitos e valores em vigor, a serem interpretados à luz da Constituição Federal de 1988, que é o diploma que define os valores e os princípios fundamentais da ordem pública.

Nesse processo evolutivo, o Poder Judiciário desempenha especial função: o juiz deixa de ser mero expectador de suas próprias decisões, passando a ter, no caso concreto, maior liberdade de atuação, tanto nas situações jurídicas típicas como naquelas não tipificadas, desde que estabeleça a conexão axiológica com os princípios adotados pela Carta Magna.

Dentre as cláusulas gerais contempladas no Código Civil em vigor, destaca-se, no campo da responsabilidade civil, a que estabelece a possibilidade da adoção do sistema objetivo de imputação, nos casos de atividade que, normalmente desenvolvida pelo autor do dano, implique risco para os direitos de outrem (artigo 927, parágrafo único, in fine).

De outro lado, a Constituição Federal de 1988 (artigo $7^{\circ}$, inciso XXVIII) contempla que a reparação dos acidentes do trabalho pode se dar, concorrentemente, sob dois diferentes regimes legais. Um, fundamentado no risco profissional, pelo qual o acidentado segurado é amparado por Seguro Social a cargo da Previdência Social, independentemente da verificação de culpa. Outro, na esfera civil, estabelece que é do empregador a responsabilidade pela indenização dos danos decorrentes do infortúnio laboral, no caso de culpa ou dolo. 
Conquanto o sistema baseado na culpa permaneça a regra geral, o regime exceptivo da responsabilidade objetiva, introduzido pelo novel Código Civil, na hipótese de a atividade normalmente desenvolvida pelo autor do dano implicar risco para os direitos de outrem, fez surgir, desde logo, a questão sobre a possibilidade de tal regime abranger as hipóteses de responsabilidade pela reparação de danos decorrentes de acidente do trabalho, especialmente nas hipóteses de atividades lícitas de risco, nada obstante a limitação contida no bojo do inciso XXVIII do artigo $7^{\circ}$ da Constituição Federal.

Porém, nada obstante passados mais de 7 anos da entrada em vigor do novo Código, a questão permanece sem orientação uniforme, divergindo os doutrinadores e a jurisprudência sobre a aplicação ou não do dispositivo à hipótese de indenização por danos decorrentes de acidente do trabalho, justificando-se, assim, a pesquisa ora proposta.

Dessa forma, no presente estudo pretendemos analisar, no âmbito do acidente do trabalho, como a responsabilidade civil objetiva avança sobre o terreno da responsabilidade subjetiva e como o entendimento dessa matéria vem se desenvolvendo no sentido de ampliar o campo de incidência do regime especial de aferição da responsabilidade.

Como recurso metodológico, o estudo foi dividido em quatro partes: três capítulos, seguidos das conclusões do pesquisador.

No Capítulo I, tratamos da responsabilidade civil, apresentando seus antecedentes históricos, principais aspectos, evolução, conceito, natureza jurídica e função, fornecendo subsídios doutrinários para o objetivo deste trabalho. O estudo concentrou-se nos aspectos evolutivos da responsabilidade civil, procurando demonstrar como a sua evolução está intimamente ligada ao processo civilizatório dos grupos sociais.

No Capítulo II, abordamos as espécies de responsabilidade civil e as teorias aplicáveis ao Direito do Trabalho. Nessa parte faz-se uma incursão sobre as espécies de responsabilidade civil, diferenciando a contratual da extracontratual e a subjetiva da objetiva, dando-se especial atenção às diversas teorias que fundamentam a derrogação do princípio geral da responsabilidade baseada na culpa e como se dá a fixação do seu campo de aplicação.

O Capítulo III foi dedicado ao estudo da responsabilidade civil por acidente do trabalho e, discorrendo sobre as especificidades da relação de emprego, apresenta o 
conceito de acidente do trabalho, a sua evolução e as teorias que se formaram em relação à obrigação da reparação civil por parte do empregador, finalizando com a exposição das correntes doutrinárias sobre a aplicação, no campo da infortunística, da parte final do parágrafo único do artigo 927 do Código Civil de 2002.

O presente trabalho foi desenvolvido mediante o uso das técnicas gerais de pesquisa, dando-se ênfase à pesquisa bibliográfica e à análise direta de legislação, tendo-se que a discussão travada sobre a responsabilidade civil do empregador atém-se a interpretação de dispositivos legais. 


\section{RESPONSABILIDADE CIVIL}

\section{Noções e conteúdo}

Toda atividade humana é aferida em termos da relação que se estabelece entre obrigação e responsabilidade, e o principal objetivo da ordem jurídica é manter o equilíbrio social, resguardando o lícito e coibindo o ilícito. A responsabilidade tem, assim, origem na necessidade do convívio em grupo e não deixa de ser um reflexo da realidade social em que se desenvolve, variando conforme cada tipo de sociedade e conforme seus princípios estruturantes.

Nesse sentido é a lição de Pontes de Miranda:

A responsabilidade resulta de fatos sociais, de relações de vida, porque também é fato social, sujeito a tentativas de caracterização e de exame em estado bruto, ou purificado de elementos que o obscureçam. Quando se pune o assassino ou o ladrão, ou a opinião pública se exalta contra o desencaminhador de mulheres, ou a família afasta do seu seio o membro que a desonrou, tais julgamentos de responsabilidade são reflexos individuais, psicológicos, de fato exterior, social, objetivo, que é a relação de responsabilidade. ${ }^{1}$

Por sua dinâmica social, é um dos temas jurídicos mais interessantes e complexos da atualidade e isso decorre do impressionante avanço tecnológico e espetacular progresso material que vem experimentando a sociedade humana, porque, nada obstante seja essa evolução geradora de utilidades e facilidades, expõe a pessoa a danos os mais variados, surgindo, a todo instante, o problema da responsabilidade, a qual, como instrumento de restabelecimento do equilíbrio social, reclama flexibilidade para apresentar soluções e remédios que restaurem tais danos. ${ }^{2}$

\footnotetext{
${ }^{1}$ MIRANDA, Francisco Cavalcanti Pontes de. Tratado de direito privado. 3. ed. São Paulo: Ed. Revista dos Tribunais, 1984. t. LIII, p. 3.

${ }^{2}$ DINIZ, Maria Helena. Curso de direito civil brasileiro: responsabilidade civil. 24. ed. São Paulo: Saraiva, 2010. v. 7, p. 3.
} 
A concepção de responsabilidade e do seu respectivo fundamento, dessa forma, não é estável. O conteúdo do seu principal fundamento, o princípio do direito natural, neminem laedere ${ }^{3}$, varia conforme o contexto em que aparece e sofre mutações com o tempo, podendo ser aferido do ponto de vista da reparação ou compensação dos danos, como efeito do descumprimento de uma obrigação ou tomada na sua dimensão preventiva, como obrigação geral anterior ao dano, objetivando diminuir os riscos que se impõem aos indivíduos e à sociedade.

A propósito, novamente recorrendo a Pontes de Miranda:

\begin{abstract}
A proibição de ofender, neminem laedere, é um dos princípios fundamentais da ordem social. Mas é princípio formal, pressupõe a determinação concreta do que é "meu" e do que é "teu", de modo que pode um ato ser ofensivo num tempo ou lugar, e não no ser noutro tempo e lugar. O que se induz da observação dos fatos é que em todas as sociedades o que se tem por ofensa não deve ficar sem satisfação, sem ressarcimento. Em vez do absolutismo, tão propício aos processos racionalistas de estudo do direito, temos de assentar, mais uma vez, a relatividade social e jurídica. O neminem laedere é, pois, um desses princípios que sintetizam a realidade formal do direito; como ao ius suum cuique tribuere e aos outros, falta-lhe conteúdo positivo. Em todo o caso, eles o pressupõem e em qualquer estágio da vida social serão inteligíveis, posto que, como as fórmulas algébricas, só nos dêem o que pusemos dentro deles. Se nada pusermos, nada teremos, porque as abstrações servem a tudo. ${ }^{4}$
\end{abstract}

A idéia de responsabilidade, desse modo, encontra-se ligada à de obrigação, ou seja, decorre e "é complementar da noção prévia mais profunda de dever e o que interessa, quando se fala em responsabilidade, é analisar as repercussões decorrentes da violação de uma norma ou de uma obrigação diante da qual se encontrava o agente." 5

O dever jurídico, por sua vez, é entendido como um conjunto de regras gerais impostas pelo direito positivo, que, por exigência da convivência social, orientam, regulam e limitam a conduta de um indivíduo dentro de um grupo.

Se o resultado da ação, da abstenção de uma ação ou da tolerância a alguma coisa encontra-se alinhado com o que ditam as normas e as regras do contexto social em

\footnotetext{
${ }^{3}$ Proposta de tradução: a ninguém se deve lesar.

${ }^{4}$ MIRANDA, Francisco Cavalcanti Pontes de. op. cit., p. 14-15.

${ }^{5}$ DIAS, José de Aguiar. Da responsabilidade civil. 10. ed. Rio de Janeiro: Forense, 1995. v. 1, p. 3.
} 
que está inserido o indivíduo, há o cumprimento da obrigação, do dever e, dessa forma, preservada a integridade do tecido social, encontra a atividade humana a tutela do ordenamento jurídico. No entanto, se o resultado contraria os preceitos dessa mesma sociedade, exsurge, como conseqüência da violação, a responsabilidade, a qual, por sua vez, pode ser de cunho moral ou jurídico.

Conquanto a teoria do direito não seja estranha à moral, para a ordem jurídica importa a manutenção do equilíbrio social e seu restabelecimento na hipótese de violação que tenha como resultado um prejuízo, tratando da repercussão que a coletividade experimenta quando é ferido um seu membro, seja do ponto de vista físico, seja na ordem patrimonial (ou moral). ${ }^{6}$

No âmbito da moral, mais amplo do que o jurídico, toda atividade humana, seja ela de natureza moral, social, ética, religiosa etc., é dotada de preceitos cuja violação, por seu alto grau de indeterminação ou sem uma conseqüência lesiva sensível ${ }^{7}$, ou seja, aferível materialmente, pode resultar no sentimento de responsabilidade moral, permanecendo a reprovação desse ato na esfera interna da pessoa, sob o signo da culpa ou do pecado. ${ }^{8}$

Assim, a responsabilidade jurídica é informada pelo princípio da equivalência e, tomada como gênero, é dividida em responsabilidade penal e responsabilidade civil, de acordo com os campos de incidência da norma e com os destinatários da proteção estatal, ou seja, a coletividade ou o indivíduo e, dessa forma, uma ação pode desencadear, a um só tempo, as duas espécies de responsabilidade.

Maria Helena Diniz expõe essa distinção:

[...] a responsabilidade penal pressupõe uma turbação social, ou seja, uma lesão aos deveres de cidadãos para com a ordem da sociedade, acarretando um dano social determinado pela violação da norma penal, exigindo para restabelecer o equilíbrio social investigação da culpabilidade do agente ou o estabelecimento da antissociabilidade do seu

\footnotetext{
${ }^{6}$ DIAS, José de Aguiar.op. cit., p. 8.

${ }^{7}$ SAVATIER, René. Traité de la responsabilité civile em droit français. Paris: Librairie Générale de Droit et Jurisprudence, 1939. t. 1, p. 39. “D’abord, qu'il s'agisse d'un devoir moral précis et d'object determiné : la violation du devoir de charité, ou de reconnaissance envers un bienfaiteur n'entraine pas de responsabilité, parce que les bénéficiaires ou l'objet de tels devoirs ne sont pas suffisamment déterminés pour qu'on puisse apprécier le préjudice causé à une personne quelconque, par celui qui les viole."

${ }^{8}$ NIETZSCHE, Friedrich Wilhelm. Genealogia da moral: uma polêmica. Tradução, notas e posfácio Paulo César de Souza. 8. reimpr. São Paulo: Companhia das Letras, 1998. p.48-49.
} 
procedimento, acarretando a submissão pessoal do agente à pena que lhe for imposta pelo órgão judicante, tendendo, portanto, à punição, isto é, ao cumprimento da pena estabelecida na lei penal. A responsabilidade civil requer prejuízo a terceiro, particular ou Estado. ${ }^{\circ}$

Entretanto, as teorias que enfocam a repercussão individual ou social do dano, para diferenciar a responsabilidade civil da penal, são severamente criticadas, na medida em que não se pode negar que o dano civil também é causa de desequilíbrio social, uma vez que mesmo o dano imposto a um único indivíduo atinge toda a sociedade. O prejuízo imposto ao particular também afeta o equilíbrio social, e daí o interesse da sociedade na sua restauração. ${ }^{10}$

Aguiar Dias, sobre essa questão, argumenta:

Isolada da responsabilidade moral, a responsabilidade jurídica logo precipita a necessidade de nova distinção. Mazeaud et Mazeaud a estabelecem, pondo em relevo que os danos que turbam a ordem social são de natureza diversa: ora atingem a coletividade, ora o indivíduo, às vezes é a ambos que alcança. A sociedade reage contra esses fatos que ameaçam a ordem estabelecida: fere o seu autor, com o propósito de impedir que volte a afetar o equilíbrio social e evitar que outros sejam levados a imitá-lo. É onde a responsabilidade jurídica se cinde em responsabilidade civil e responsabilidade penal. ${ }^{11}$

Com mesma origem e fundamentos idênticos, a distinção entre responsabilidade penal e civil recai nas formas adotadas para a restauração da ordem social, cuidando a sociedade dos atos que lhe atingem, de forma direta, e o terceiro (particular ou Estado), munido do direito de ação em face do ofensor, da recomposição do seu dano individualmente experimentado.

Estabelecem-se, assim, em lei, as situações consideradas prejudiciais à paz social e que serão objeto de ação repressora do poder público, enquanto a responsabilidade civil é aferida quando verificado um prejuízo (ação restitutiva ${ }^{12}$ ).

\footnotetext{
${ }^{9}$ DINIZ, Maria Helena. op. cit., p. 23.

${ }^{10}$ AZEVEDO, Álvaro Villaça. Teoria geral das obrigações e responsabilidade civil. 11. ed. São Paulo: Atlas, 2008. p. 243.

${ }^{11}$ DINIZ, Maria Helena. op. cit., p. 4.

${ }^{12}$ MIRANDA, Francisco Cavalcanti Pontes de. op. cit., p. 14.
} 
Como se vê, a responsabilidade civil confunde-se com a própria noção de direito, porquanto todo ato, fato ou negócio que causa um prejuízo acarreta a responsabilidade ou o dever de indenizar por parte do causador do dano.

A composição do prejuízo surge, então, como dever sucessivo do dever originário violado $^{13}$, e que pode ensejar medida legal a fim de fazer cumprir a obrigação violada, de fazer reparar o dano causado ou de infundir respeito à ordem jurídica. ${ }^{14}$

Assim, com fundamento na harmonia e no equilíbrio social, a responsabilidade civil é instituto dinâmico, que não se sujeita a tratamento estanque. Exige transformação na mesma velocidade das transformações sociais, para oferecer, em qualquer época, meio ou processo para o restabelecimento do equilíbrio abalado pelo dano, sob pena de deixar o direito alheio à realidade social. ${ }^{15}$

Por isso verifica-se, nos ordenamentos jurídicos contemporâneos, a tendência de alargamento do dever de indenizar, para que cada vez menos existam danos sem reparação. ${ }^{16}$

Uma vez apresentada a noção de responsabilidade civil, faz-se necessário, então, para uma melhor compreensão do tema, abordar a sua evolução.

\section{Evolução}

É da natureza humana reagir a atos que atentem contra a pessoa, a família ou o grupo a que se pertence ${ }^{17}$. Essa constatação histórica explica o regime da vingança privada a que esteve submetida a humanidade até o aparecimento dos primeiros sistemas jurídicos de que se tem notícia, e a história do mundo dá conta de que a responsabilidade é preocupação imanente a toda sociedade minimamente organizada.

\footnotetext{
${ }^{13}$ CAVALIERI FILHO, Sérgio. Programa de responsabilidade civil. 8. ed. São Paulo: Atlas, 2008. p. 2.

${ }^{14}$ DINIZ, Maria Helena. op. cit., p. 8.

${ }^{15}$ DIAS, José de Aguiar.op. cit., p. 6.

${ }^{16}$ VENOSA, Sílvio de Salvo. Direito civil: responsabilidade civil. 9. ed. São Paulo: Atlas, 2009. p. 9-10.

${ }^{17}$ Id. Ibid., p. 16.
} 
$\mathrm{Na}$ fase de responsabilidade não regulamentada, imperava a idéia da retribuição do mal pelo mal, sem método, sem sistema e sem proporcionalidade ${ }^{18}$. Trata-se de vingança pura e simples, pelas próprias mãos da vítima de uma lesão. ${ }^{19}$

Com a evolução da humanidade e na medida em que os grupos sociais se consolidam, há um crescente interesse na resolução dos conflitos intersubjetivos; todavia, o abandono da vingança privada não se dá de forma instantânea.

Como se infere do Código de Hamurabi (1792-1750 a.C.), na Mesopotâmia, ainda sob a premissa da retribuição do mal pelo mal, a regra jurídica manteve a vingança como forma de reparação de danos, estabelecendo, no entanto, quando e em que condições a vítima tinha direito de exercê-la ${ }^{20}$. A humanidade, com isso, enceta a era da vingança privada regulamentada pelo poder público.

Em Roma, com a expressão si membrum rupsit ni cum eo pacit talio ${ }^{21}$ est (se alguém fere a outrem, que sofra a pena de talião, salvo se existiu acordo) ${ }^{22}$, a mesma regra foi instituída pela Lei das XII Tábuas (451-441 a.C.) e, ainda que sem um princípio geral da responsabilidade, teve o mérito de, reconhecendo que a sociedade também era atingida por lesões infligidas aos particulares, fixar regras para o seu exercício e, de forma acanhada, atribuir ao poder público a direção da composição dos $\operatorname{conflitos}^{23}$, o que representou um grande avanço para o direito, conforme dão conta estudos de Cretella Júnior:

Embora aos nossos olhos a pena de talião se afigure brutal, significa, no entanto, grande progresso para a história do direito. Na fase anterior, em face do delito praticado por uma pessoa, pagava não só ele (às vezes nem ele), como outros de sua família. Com o talião o castigo alcança o autor do delito e a idéia de proporção entre a ofensa e o castigo se vai esboçando, afirmando-se cada vez mais ${ }^{24}$.

\footnotetext{
${ }^{18}$ CRETELLA JÚNIOR, José. Curso de direito romano: o direito romano e o direito civil brasileiro. 7. ed. Rio de Janeiro: Forense, 1980. p. 303.

${ }^{19}$ LIMA, Alvino. Culpa e risco. 2. ed. rev. e atual. Pelo Prof. Ovídio Rocha Barros Sandoval. São Paulo: Ed. Revista dos Tribunais, 1998. p. 20.

${ }^{20}$ DIAS, José de Aguiar. op. cit., p. 17.

${ }^{21}$ CRETELLA JÚNIOR, José. op. cit., p. 304. Obs. Tálio, onis, $m$. talião = tal. Assim, tal delito, tal vingança.

${ }^{22}$ DINIZ, Maria Helena. op. cit., p. 11.

${ }^{23}$ DIAS, José de Aguiar. op. cit., p. 17.

${ }^{24}$ CRETELLA JÚNIOR, José. op. cit., p. 304.
} 
Com o desenvolvimento da sociedade e com a compreensão de que cobrar a retaliação impunha duplicar o dano, especialmente na hipótese de dano involuntário, passou a ser admitida a composição ao exclusivo alvitre do ofendido, quando o causador do dano, para adquirir o direito ao perdão, prestava, em dinheiro ou em bens, uma forma de multa compensatória substitutiva da vingança (pœena).

A essa fase sucedeu a da composição legal de natureza obrigatória, na qual o poder público intervinha, estabelecendo, em lei, valores que o ofensor era obrigado a pagar à vítima, tendo esta de submeter-se ao valor fixado.

A propósito, ensina José de Aguiar Dias:

Vulgariza-se a composição voluntária e, por fenômeno análogo ao da admissão do talião, o legislador sanciona o uso. Veda à vítima, daí em diante, fazer justiça com as próprias mãos, compelindo-a a aceitar a composição fixada pela autoridade. ${ }^{25}$

Em fase posterior, o Estado arrogou a si a função de, com exclusividade, punir o causador do dano, impondo, com isso, o desdobramento da concepção de responsabilidade em penal e civil. $^{26}$

Porém, é na Lei Aquília (Lex Aquilia - fins do século III ou início do século II a.C. ${ }^{27}$ ) que a doutrina identifica a adoção de um princípio geral regulador da reparação do dano, conquanto desprovido de regra de conjunto como a que se verifica no direito atual. ${ }^{28}$

A Lex Aquilia foi um plebiscito proposto por um tribuno da plebe, Aquilius ${ }^{29}$, provocado pelos plebeus para se protegerem contra os prejuízos que lhes causavam os patrícios nos limites de suas propriedades. ${ }^{30} \mathrm{O}$ texto autêntico dessa lei não chegou até a atualidade; o conhecimento do seu conteúdo provém de referências que, de forma uniforme, a ela fazem numerosos documentos, conforme se constata das Institutas de Gaio

\footnotetext{
${ }^{25}$ DIAS, José de Aguiar. op. cit., p. 17.

${ }^{26}$ Id. Ibid, p. 16.

${ }^{27}$ VENOSA, Sílvio de Salvo. op. cit., p. 17.

${ }^{28}$ DIAS, José de Aguiar. op. cit., p. 18.

${ }^{29}$ FRANÇA, R. Limongi. op. cit., p. 247.

${ }^{30}$ CRETELLA JÚNIOR, José. op. cit., p. 313.
} 
(3, 202 e 210-219); nas Institutas de Justiniano (4,3); no Digesto (9, 2) e no Código (3, $35)^{31}$

Criteriosa pesquisa de Limongi França revelou que as informações mais claras e ordenadas sobre a Lei Aquília são dadas pelo jurisconsulto Gaio, nas Institutas (3, 210210), o qual, com suas próprias palavras, procurou sintetizar o conteúdo desse documento:

\section{CAPÍTULO PRIMEIRO}

I - Se alguém matar injustamente um escravo alheio ou um quadrúpede... seja condenado a pagar o maior valor da coisa durante esse ano (... si quis hominem alienum alie namve quadrupedem... injuria occiderit, quanti ea res in eo anno plurimi fuerit, tantum domino dare danetur).

II - Entende-se que matou injustamente aquele que o fez com dolo ou culpa (Is injuria autem occidere intelligitur, cuius dolo aut culpa id occiderit...).

III - Pela ação fundada nesta lei, computa-se não somente o preço do corpo, mas, ainda, se o dono... sofreu um prejuízo superior... também este prejuízo é computado (Nec solum corpus in actione huius legis aestimatur, sed... si plus dominus capiat... id quoque aestimatur).

IV - Deve considerar-se também o prejuízo sofrido pelos sobreviventes, se o morto faz parte de um conjunto (Item si... unus occisus fuerit, non solum occisi fit aestimatio, sed eo amplius id quoque computatur, quod ceteri que supersunt depreciati sunt.)

$\mathrm{V}$ - Aquele cujo escravo foi morto pode escolher entre tornar o responsável réu de crime ou cobrar o dano (Cuius autem servus occisus est, is leberum arbitrium habet, vel capitali crimine reum facere eum qui occiderit, vel... damnum persequi.)

\section{CAPÍTULO SEGUNDO}

VI - O credor tem ação pelo montante da dívida contra o adstipulante que exonera o devedor em fraude (... adversus adstipulatorem, qui pecuniam in fraudem stipulatoris acceptam fecerit, quanti ea res est, tanti actio constituitur.)

\footnotetext{
${ }^{31}$ FRANÇA, R. Limongi. op. cit., p. 248.
} 
VII - Por esta lei, o responsável que nega o fato deve pagar em dobro (... ea lege adversus infitiantem in duplim agit.)

\section{CAPÍTULO TERCEIRO}

VIII - Deve responder pelo prejuízo quem quer que cause a outrem qualquer espécie de dano, devendo ser condenado a pagar não o valor da coisa durante todo o ano anterior ao dano, mas seu maior valor durante os trinta dias precedentes (... de omni damno cavetur. - ... non quanti in eo anno, sed quanti in diebus $X X X$ proximis ea res fuerit, damnatur is, qui damnum dederit.)

IX - Esta ação só cabe quando o dano é causado com o próprio corpo, devendo exercer-se actiones utiles, se se tratar de dano perpetrado de outro modo, como matar um animal de fome (Ceterum placuit ita demum ex ista lege actionem esse, si quis corpore suo damnum dederit; ideoque alio modo damno dato utiles actiones dantur; veluti si quis... pecude... fame necaverit.). ${ }^{32}$

Constituída, assim, de três capítulos, a Lei Aquília reúne, nos dois primeiros, disposições que se encontravam dispersas e isoladas no regime da Lei das XII Tábuas, tratando da morte de escravos ou de animais, no primeiro, e, no segundo, regulando a quitação por parte do adstipulator com prejuízo do estipulante (abatimento da dívida com o prejuízo do primeiro). O terceiro capítulo introduziu como fonte de obrigação um novo delito civil de caráter mais amplo, denominado damnum injuria datum, com o objetivo de regular o prejuízo sem justificativa legal causado à coisa alheia (lesões a escravos ou animais e destruição ou deterioração de coisas corpóreas), sem que isso representasse, de outro lado, enriquecimento do ofensor ${ }^{33}$. Com isso, o ofendido titular de bens destruídos ou deteriorados passou a ter o direito ao pagamento de uma penalidade em dinheiro por parte daquele cuja conduta tivesse sido, de forma injusta, a causa dos respectivos danos. ${ }^{34}$

O capítulo três é, para o direito, a parte mais importante para compreensão da evolução da responsabilidade civil, especialmente no que tange à responsabilidade extracontratual ${ }^{35}$; mas é importante frisar que, conquanto a Lex Aquilia seja comumente apontada como referencial da responsabilidade extracontratual, também trata ela da

\footnotetext{
${ }^{32}$ FRANÇA, R. Limongi. op. cit., p. 249-250.

${ }^{33}$ DIAS, José de Aguiar. op. cit., p. 18.

${ }^{34}$ VENOSA, Sílvio de Salvo. op. cit., p. 17.

${ }^{35}$ GAGLIANO, Pablo Stolze; PAMPLONA FILHO, Rodolfo. Novo curso de direito civil: responsabilidade civil. 7. ed. São Paulo: Saraiva, 2009. v. 3, p. 10-11.
} 
responsabilidade contratual, conforme o capítulo II, sobre a alienação do adstipulator em fraude de credores. ${ }^{36}$

$\mathrm{Na}$ sua origem casuística e restrito campo de aplicação, considerando o ato ilícito uma figura autônoma, ou seja, independentemente de uma relação obrigacional preexistente, a Lex Aquilia ainda não continha uma concepção clara da culpa.

A ampliação do conceito da responsabilidade aquiliana só se deu no fim da República, quando a jurisprudência, sob a influência do ideário grego, identificou, no ato injusto, o princípio que animava o instituto e localizou o fundamento da responsabilidade na quebra do equilíbrio patrimonial provocado pelo dano. ${ }^{37}$ Com essa compreensão o campo de incidência do damnum injuria datum, antes restrito ao romano proprietário da coisa destruída ou deteriorada, foi, em um primeiro momento, ampliado, para incluir os titulares de outros direitos reais e os peregrinos ${ }^{38}$, podendo ser observada, na última fase do direito romano, a multiplicação de textos que autorizavam ações de responsabilidade tanto por danos materiais quanto por danos morais. ${ }^{39}$

Aperfeiçoando as idéias romanas, o direito francês abandonou o critério de enumerar os casos de composição obrigatória e estabeleceu um princípio geral da responsabilidade civil, servindo de modelo e inspiração para a legislação moderna que adotou a culpa como fundamento. ${ }^{40}$ Nas palavras do jurista francês Domat, idealizador do princípio geral da responsabilidade civil (Lois civiles, liv. VIII, Seção II, art. $1^{\circ}$ ), citado por Maria Helena Diniz ${ }^{41}$ :

Toutes les pertes et tous les dommages qui peuvent arriver par le fait de quelque personne, soit imprudence, légéreté, ignorance de ce qu'on doit savoir, ou autres fautes semblables, si légères qu'elles puissent être, doivent être réparées par celui dont l'imprudence ou autre faute y a donné lieu. ${ }^{42}$

\footnotetext{
${ }^{36}$ FRANÇA, R. Limongi. Responsabilidade aquiliana e suas raízes. In: CAHALI, Yussef Said (Coord.). Responsabilidade civil: doutrina e jurisprudência. 2. ed. São Paulo: Saraiva, 1988. p. 252.

${ }^{37}$ VENOSA, Sílvio de Salvo. op. cit., p. 17.

${ }^{38}$ DIAS, José de Aguiar. op. cit., p. 43.

${ }^{39}$ Id. Ibid., p. 20.

${ }^{40}$ Id. Ibid., p. 21.

${ }^{41}$ DINIZ, Maria Helena. op. cit., p. 12.

${ }^{42}$ Proposta de tradução: todas as perdas e todos os danos que podem dar-se pelo fato de alguma pessoa, seja imprudência, negligência, ignorância do que se deve saber, ou outras faltas semelhantes, por mais leves que possam ser, devem ser reparados por aquele cuja imprudência ou outra falta a eles deu causa.
} 
Essa nova orientação foi adotada pelo Código Civil francês, de 21 de março de 1804, que prescreve, no seu artigo 1.382: tout fait quelconque de l'homme, que cause à autrui un dommage, oblige celui par la faute duquel il est arrivé, à la réparer ${ }^{43}$.

Porém, no dia-a-dia, frente a uma realidade globalizada com a introdução de máquinas pelo processo industrial (Revolução Industrial), produção de bens em larga escala, surgimento de novas tecnologias, dentre outras ponderosas transformações sociais, verificou-se que a culpa, como elemento de caracterização da responsabilidade civil, não mais era suficiente para abarcar todas as hipóteses de dano, ${ }^{44}$ levando a uma reformulação da teoria da responsabilidade civil dentro de um processo de humanização, sob a idéia de que todo risco deve ser garantido ${ }^{45}$, o que promoveu uma crescente objetivação da idéia de culpa. $^{46}$

Dissertando sobre essa questão, Teresinha Lorena Pohlmann Saad escreve:

Assim, sob a influência da evolução social surgiu a par da teoria romana da responsabilidade civil fundada na culpa, a teoria da responsabilidade objetiva, que no campo da indústria recebe o nome de teoria do risco profissional, expressão que, como explica Cunha Gonçalves, se refere à profissão do patrão e ao risco inerente à sua atividade, e não à profissão do trabalhador, que não deve suportar o respectivo risco. ${ }^{47}$

Essa modificação de enfoque representou uma dramática evolução para a teoria da responsabilidade civil, porquanto surgida no contex to do Estado Liberal. Entretanto, foi o próprio modelo de produção capitalista que, disseminando o uso de máquinas, em especial pelo aumento dos riscos que acarretam, criou um novo tipo de dano que não era alcançado pelo sistema clássico, ou seja, verificou-se que, em muitas hipóteses de acidentes do trabalho, não há um comportamento positivo (ação) ou negativo (omissão) contrário à ordem jurídica ${ }^{48}$ ou, quando presente, a prova da conduta ilícita, no mais das

\footnotetext{
${ }^{43}$ Proposta de tradução: todo ato do homem que causa um dano a outrem obriga o responsável que agiu com culpa a repará-lo.

${ }^{44}$ SAAD, Teresinha Lorena Pohlmann. Responsabilidade civil da empresa nos acidentes do trabalho. São Paulo: LTr, 1993. p. 28.

${ }^{45}$ MIRANDA, Francisco Cavalcanti Pontes de. op. cit., p. 14.

${ }^{46}$ BITTAR, Carlos Alberto. Responsabilidade civil nas atividades perigosas. In: CAHALI, Yussef Said (Coord.). Responsabilidade civil: doutrina e jurisprudência. 2. ed. São Paulo: Saraiva, 1988. p. 92.

${ }^{47}$ SAAD, Teresinha Lorena Pohlmann. op. cit., p. 22.

${ }^{48}$ BITTAR, Carlos Alberto. op. cit., p. 95.
} 
vezes, é quase impossível para o empregado. ${ }^{49}$ Por essa teoria, se os danos decorrem do risco geral de qualquer atividade laboral, há responsabilidade objetiva do empregador detentor do risco, devendo ser garantido por seguro social ou seguro privado obrigatório.

Fernando José Cunha Belfort, dissertando sobre as forças sociais que forjaram a responsabilidade baseada no risco, esclarece que:

O Estado passou a ser socialmente conformador e economicamente interventor. O direito fiscaliza e limita a autonomia da vontade, mesmo porque historicamente ficou comprovado que essa autonomia poderia levar - como afinal levou - a situações de profundas desigualdades - se não formais, certamente materiais. ${ }^{50}$

É nesse ambiente que doutrina e jurisprudência reconheceram a nova força desencadeadora de responsabilidade civil e, juntas, passaram a buscar alternativas para assegurar às vítimas a necessária reparação, ampliando os domínios da culpa ou propondo nova forma de imputação da responsabilidade baseada no dano. ${ }^{51}$

Essa movimentação do Direito, no sentido de dar resposta aos novos fenômenos sociais, é muito bem resumida por Carlos Alberto Bittar:

Sustentou-se, de início, a técnica da dispensa de prova em concreto, como um primeiro passo para a humanização da responsabilidade civil, em razão da posição das vítimas, geralmente trabalhadores sem recursos. Mecanismos de presunção também foram cogitados e enraizaram-se em alguns Códigos e, mesmo, em leis especiais. Mas foi somente a partir da edição de leis especiais, liberadas da subjetividade, sobre responsabilidade civil - primeiro, na área de acidentes do trabalho e, depois, em atividades empresariais de certos setores - que a teoria em questão ganhou nova fonte geradora, ou seja, o simples exercício de atividade carregada de perigo. ${ }^{5}$

\footnotetext{
${ }^{49}$ BIELSA, Rafael. La culpa en los accidentes del trabajo. 2. ed. Buenos Aires: J. Lajouane \& Cia, 1926. p. 61.

${ }^{50}$ BELFORT, Fernando José Cunha. A responsabilidade objetiva do empregado nos acidentes de trabalho. São Paulo: LTr, 2010. p. 22.

${ }^{51}$ BITTAR, Carlos Alberto. op. cit., p. 94.

${ }^{52}$ Id. Ibid.
} 
Por esse novo fundamento de aferição da responsabilidade, há obrigação de reparar o dano pela simples criação ou controle do risco pelo homem, ou seja, o dano e a reparação não são aferidos pela medida da culpabilidade, mas sim pelo fato causador da lesão de um bem jurídico. ${ }^{53}$ É a chamada responsabilidade objetiva fundada no princípio da eqüidade, já conhecida desde o direito romano (ubi emolumentum, ibi onus). ${ }^{54}$

\section{Evolução da responsabilidade civil no Brasil}

No Brasil colonial, enquanto na França eram travados calorosos debates acerca da responsabilidade civil, vigiam as Ordenações do reino oriundas do direito português, com trajetória muito diferente da legislação francesa.

Com forte influência germânica, fruto da invasão dos visigodos ${ }^{55}$, a primitiva legislação portuguesa, ainda sem separar a responsabilidade civil da penal, acolhia, a um só tempo, a composição germânica e o critério penal dos romanos e, mesmo no período do direito consuetudinário, que predominou após a invasão árabe, nada obstante a aplicação constante da reparação pecuniária, os tribunais ainda admitiam as penas corporais e o uso da vingança privada ${ }^{56}$.

Após a Constituição do Império, o primeiro diploma a tratar da responsabilidade civil foi o Código Criminal de 1830, o qual, cumprindo a recomendação constitucional de organização de um código civil e de um código penal, previu, no seu artigo 21, a reparação do dano causado pelo delinqüente ${ }^{57}$. A partir desse diploma legal, a idéia de reparação de danos observou tímida evolução, salvo alguns poucos trabalhos inovadores, tais como a Consolidação de Teixeira de Freitas e a nova Consolidação de Carlos de Carvalho, as quais cogitaram da responsabilidade civil, bem assim, a Lei n.

\footnotetext{
${ }^{53}$ BITTAR, Carlos Alberto. op. cit., p. 105.

${ }^{54}$ MIRANDA, Francisco Cavalcanti Pontes de. op. cit., p. 48.

${ }^{55}$ CRETELLA JÚNIOR, José. op. cit., p. 68. "O Breviário de Alarico, Lei romana dos visigodos, Corpo das leis ou Breviário de Aniano é uma compilação de leis, feita em 506, por ordem de Alarico II e homologada por Aniano. Como se sabe, os bárbaros respeitavam os costumes dos povos vencidos, deixando-os que se regessem por suas respectivas leis. Por isso, quando os visigodos invadiram a península, permitiram que os povos peninsulares seguissem as próprias leis, que eram romanas e, para isso, organizaram os vencedores um código que ofereceram aos vencidos."

${ }^{56}$ DIAS, José de Aguiar. op. cit., p. 23.

${ }^{57}$ Id. Ibid.
} 
2.681/1912, que estabeleceu a responsabilidade objetiva para as empresas de transporte ferroviário $^{58}$.

O próprio Código Civil de 1916 é, desde sua promulgação, tachado de antiquado, conforme registra Aguiar Dias:

O que se observa, em conclusão, no direito brasileiro, é que libertando-se das fórmulas confusas das Ordenações, e estabelecendo-se, por certo tempo, em plano de melhor compreensão da responsabilidade civil, efetuou evidente retrocesso, por intermédio de várias disposições do Código Civil. ${ }^{59}$

Essa origem, de certa forma, revela a inclinação inicial da doutrina e da jurisprudência brasileira à interpretação restritiva do instituto e, nada obstante toda a evolução da responsabilidade civil observada em nosso país, principalmente nos anos setenta e oitenta, muitas questões, tal como a referente ao dano moral, permaneceram, até muito recentemente, sob caloroso debate sobre o seu cabimento ${ }^{60}$, quando essa já era, desde o século XIX, uma questão pacificada nos países diretamente influenciados pelo Código Civil francês ${ }^{61}$, como atesta Aguiar Dias:

\begin{abstract}
A evolução do direito francês nos tempos modernos dispensa considerações mais longas. Basta recordar que se deu através da mais extraordinária obra de jurisprudência de todos os tempos. A tarefa dos tribunais franceses, atualizando os textos e criando um direito rejuvenescido, foi tão impressionante que não há quem a desconheça, na audácia fecunda que é um dos encantos do gênio francês. ${ }^{62}$
\end{abstract}

\footnotetext{
${ }^{58}$ PEREIRA, Caio Mário da Silva. Direito civil: alguns aspectos da sua evolução. Rio de Janeiro: Forense, 2001. p. 110.

${ }^{59}$ Id. Ibid., p. 29.

${ }^{60}$ RIZZARDO, Arnaldo. Responsabilidade civil: Lei $\mathrm{n}^{\circ}$ 10.406, 10.01.2002. 3. ed. Rio de Janeiro: Forense, 2007. p. 251. "No início, os doutrinadores que precederam e vieram logo após à vigência do Código Civil de 1916 não reconheciam a reparação por dano moral. Ligava-se a indenização por morte ao então art. 1.537 (que no Código atual corresponde ao seu art. 948), e restrita aos danos materiais e às prestações de alimentos. Deste ponto avançou-se para a indenização do dano causado pela morte de filho menor - marco inicial para a evolução do direito nesse campo, e chegando-se à Súmula no 491 do STF: "É indenizável o acidente que causa a morte de filho menor, ainda que não exerça trabalho remunerado". Havia um misto de embasamento patrimonial e moral"

${ }^{61}$ PEREIRA, Caio Mário da Silva. op. cit., p. 119. "René de Page, doutrinando com base no Código de Napoleão, e recuando aos trabalhos preparatórios, raciocinava que a disposição do art. 1.382 abrangia, em sua vasta largueza, todos os gêneros de danos (Traité Elementaire de Droit Civil Belge, vol. III, no 951), o que não excluía os danos morais."

${ }^{62}$ DIAS, José de Aguiar. op. cit., p. 20-21.
} 
Mas, não se pode olvidar que, reconhecendo a impossibilidade de prever a evolução da responsabilidade civil, o legislador de 1916, de forma proposital, não tratou da matéria de forma ordenada, tendo apenas traçado os seus fundamentos em forma de cláusula aberta, aparelhando o instituto de flexibilidade para viabilizar o desenvolvimento do instituto conforme se dava o desenvolvimento da sociedade. ${ }^{63}$

Há um visível esforço no sentido de criar uma regra geral para abarcar todos os fatos que causam desequilíbrio social, estabelecendo a culpa como fundamento principal e admitindo, excepcionalmente, hipóteses legais de responsabilidade sem culpa.

O Código Civil brasileiro de 2002, da mesma forma, embora dedique um capítulo específico à responsabilidade civil (Título IX, do Livro I, da Parte Especial), também não dispensou tratamento legislativo exaustivo a essa matéria e, aliando a técnica normativa das cláusulas gerais, fez seus princípios e normas encontradiços por todo o Código, porque, como bem sintetizou Cavalieri Filho, "tudo ou quase tudo em direito acaba em responsabilidade" ${ }^{, 64}$.

Em sede de responsabilidade civil, a grande inovação trazida no novo código foi, sem dúvida, a segunda parte do seu art. 927, ao estabelecer, ao lado das hipóteses legais, cláusula geral de responsabilidade objetiva "quando a atividade normalmente desenvolvida pelo autor do dano implicar, por sua natureza, risco para os direitos de outrem".

Essa é a tendência dos códigos mais avançados, como observa Carlos Alberto Bittar:

No plano normativo, nas atividades perigosas, as regras vêm editadas conforme exposto, em leis apartadas das codificações, constituindo, portanto, direito especial. Nota-se, no entanto, a sua inserção também nos Códigos mais modernos, que vêm procedendo à internação, em seu contexto, de alguns desses casos especiais de responsabilidade, como o Código Civil italiano, o espanhol e o português, dentre outros. Ademais, os Códigos atuais vêm formulando, por expresso, o princípio geral de responsabilidade por risco - inexistente até então - incorporando-o,

\footnotetext{
${ }^{63}$ DIAS, José de Aguiar. op. cit., p. 16.

${ }^{64}$ CAVALIERI FILHO, Sérgio. op. cit., p. xxii. "A responsabilidade civil é uma espécie de estuário onde deságuam todas as áreas do Direito - Público e Privado, contratual e extracontratual, material e processual; é uma abóbada que concentra e amarra toda a estrutura jurídica, de sorte a não permitir centralização de toda a sua disciplina."
} 
conseqüentemente, ao direito legislado e firmando-o, de modo definitivo, na consciência jurídica dos povos. ${ }^{65}$

O alcance da inovação trazida pelo novel Código Civil, contudo, ainda não foi perfeitamente delimitado. Para alguns, a novidade é festejada como meio de reparar danos provocados por atividade de risco normalmente desenvolvida pelo autor, antes não abarcados pelo sistema baseado na culpa, enquanto, para outros, sem operatividade frente aos comandos constitucionais pátrios, a adoção de cláusula geral de responsabilidade objetiva com base no risco da atividade sem qualquer excludente, decorre de cópia equivocada da legislação italiana e portuguesa ${ }^{66}$, porque, desprezando o fundamento da existência dessa regra naqueles países, principalmente no que toca à prevenção, quebrou a lógica do instituto ${ }^{67}$.

Pode-se observar, com base no que foi apresentado até aqui, que a evolução da responsabilidade civil na Europa e no Brasil tem uma diferença substancial. Tal compreensão é importante para a abordagem do tema objeto desta dissertação. Igualmente importante é conhecer o conceito da responsabilidade civil, motivo pelo qual o item a seguir traz uma apresentação geral sobre o tema.

\section{Conceito}

Conceituar um fenômeno, segundo Maurício Godinho Delgado, “consiste na atividade intelectual de apreensão e desvelamento dos elementos componentes desse fenômeno e do nexo lógico que os mantêm integrados". ${ }^{68}$

Assim, o termo "responsabilidade" pode ter várias acepções. Para Aguiar Dias, pode ser entendido a partir de vários pontos de vista, tais como: do leigo, da psicologia normal, da psicologia patológica, da antropologia criminal etc. $\mathrm{O}$ direito, no entanto, trabalha com a acepção sociológica da expressão "responsabilidade", porque,

\footnotetext{
${ }^{65}$ BITTAR, Carlos Alberto. op. cit., p. 104.

${ }^{66}$ LOPEZ, Teresa Ancona. Principio da precaução e evolução da responsabilidade civil. São Paulo: Quartier Latin, 2010. p. 163.

${ }^{67}$ Id. Ibid., p. 161-162.

${ }^{68}$ DELGADO, Maurício Godinho. Curso de direito do trabalho. 5. ed. São Paulo: LTr, 2006. p. 489.
} 
juridicamente, resulta ela de fatos sociais, não deixando ela própria de ser um fato social de onde se manifestam as regras (os princípios jurídicos são simples expressões dos fatos da vida). ${ }^{69}$

Nesse contexto, a palavra responsabilidade tem origem no verbo latino respondere, de spondeo (responder a, comprometer-se, prometer) que, no direito quiritário, fazia parte da fórmula como o devedor, por meio de pergunta e resposta, assumia uma obrigação com o credor, nos contratos verbais. ${ }^{70} \mathrm{O}$ credor, pronunciando palavras específicas, perguntava: dare mihi spondes? ${ }^{71}$ E o devedor respondia: spondeo ${ }^{72} \cdot{ }^{73}$

A vertiginosa evolução da idéia inicial de reparação pelo descumprimento de uma obrigação extracontratual, bem assim de todos os aspectos que lhe dão conformação, principalmente no período que se seguiu à promulgação do Código Civil francês, conferiu tão alto grau de complexidade ao instituto, que muitos doutrinadores admitem que a tarefa de propor-lhe uma definição poderia revelar-se superficial ou incompleta.

Constatando a profusão teórica e jurisprudencial para a apreciação, análise e aplicação da responsabilidade civil, Giselda Maria F. Novaes Hironaka afirma que:

Ao lado dessa prodigalidade de formulações teóricas se instalaram, também, e de modo igualmente pródigo, as mais diferentes tendências jurisprudenciais, com respostas distintas para casos semelhantes, com respostas semelhantes para casos distintos e com idênticas respostas para casos semelhantes ou não, mas oriundos de fundamentação diversa. ${ }^{74}$

A título de exemplo desse zelo para a formulação de um conceito, Aguiar Dias menciona a preocupação dos irmãos Mazeaud:

O dissídio que lavra na doutrina, com relação ao problema da responsabilidade civil, alcança todos os seus aspectos. E começa, naturalmente, pela sua definição, a cujo propósito se manifestam divergências tão profundas - a acusar a luta, fecunda em conseqüências,

\footnotetext{
${ }^{69}$ MIRANDA, Francisco Cavalcanti Pontes de. op. cit., p. 3.

${ }^{70}$ AZEVEDO, Álvaro Villaça. op. cit., p. 243.

${ }^{71}$ Proposta de tradução: prometes-me?

${ }^{72}$ Proposta de tradução: prometo.

${ }^{73}$ DINIZ, Maria Helena. op. cit., p. 33.

${ }^{74}$ HIRONAKA, Giselda Maria Fernandes Novaes. Responsabilidade pressuposta. Belo Horizonte: Del Rey, 2005. p. 119.
} 
entre a concepção tradicional da culpa e a doutrina moderna do risco que Mazeaud et Mazeaud, não obstante sua colocação entre os maiores pesquisadores da matéria, não hesitam em confessar a tentação de enfrentar o tema sem o definir. ${ }^{75}$

Imbuído da mesma cautela, para Savatier responsabilidade civil é l'obligation qui peut incomber à une personne de réparer le dommage causé à autrui par son fait, ou par le fait des personnes ou des choses dépendantes d'elle. ${ }^{76}$

Comentando a conceituação formulada pelo autor francês, Sílvio Rodrigues assevera que a questão demanda, em um primeiro momento, estabelecer se o prejuízo verificado deve ser reparado por quem o causou, para depois examinar em que condições e de que maneira será o prejuízo reparado. ${ }^{77}$

Corroborando a dificuldade de conceituação do instituto, Maria Helena Diniz faz referência a autores que baseiam sua definição na culpa, enquanto outros, como Josserand, apontando a inaptidão do sistema tradicional para resolver todas as questões que envolvem o tema responsabilidade civil, como é o problema da responsabilidade por fato de outrem, abordam o tema sob um aspecto mais amplo, vislumbrando a responsabilidade civil como uma questão de repartição de prejuízos causados, equilíbrio de direitos e interesses $^{78}$, ou seja, definem-na à luz da doutrina do risco. ${ }^{79}$ Portanto, essa divergência de fundamentos revela a existência de dois sistemas: o subjetivo, baseado na culpa, e o objetivo, que consagra a teoria do risco criado.

Contudo, antes de excluírem-se, são sistemas que se completam. Se, por um lado, a culpa revelou-se insuficiente como solução unitária para a caracterização da responsabilidade, a concepção materialista do direito, focada na causalidade, também sofre a pecha de incompletude, porque exclui a pessoa da relação jurídica.

É esclarecedora a lição de Aguiar Dias:

\footnotetext{
${ }^{75}$ DIAS, José de Aguiar. op. cit., p. 13.

${ }^{76}$ SAVATIER, René. op. cit., p. 1.

${ }^{77}$ RODRIGUES, Silvio. Direito civil: responsabilidade civil. 20. ed. 5. tir. São Paulo: Saraiva, 2003. v. 4, p. 6.

${ }^{78}$ DINIZ, Maria Helena. op. cit., p. 34.

${ }^{79}$ DIAS, José de Aguiar. op. cit., p. 44.
} 
Culpa e risco são títulos, modos, casos de responsabilidade civil. Não importa que a culpa conserve a primazia, como fonte da responsabilidade civil, por ser o seu caso mais freqüente. $\mathrm{O}$ risco não pode ser repelido, porque a culpa muitas vezes é, sob pena de sancionar-se uma injustiça, insuficiente como geradora da responsabilidade civil. ${ }^{80}$

Maria Helena Diniz arrisca-se e formula o conceito de responsabilidade civil, nos seguintes termos:

A responsabilidade civil é a aplicação de medidas que obriguem alguém a reparar dano moral ou patrimonial causado a terceiros, em razão de ato próprio imputado, de pessoa por quem ele responde, ou de fato de coisa ou animal sob sua guarda, ou, ainda, de simples imposição legal (vários autores). Definição esta que guarda em sua estrutura, a idéia de culpa quando se cogita da existência de ilícito (responsabilidade subjetiva), e a do risco, ou seja, da responsabilidade sem culpa (responsabilidade objetiva). ${ }^{81}$

Nessa sua definição a prestigiada autora ressalta a função da responsabilidade civil no sentido de garantir a reparação ao lesado, enfatiza o necessário confronto entre duas pessoas e contempla os dois sistemas para a caracterização do dever de indenizar.

Contudo, ainda que essa definição esteja alinhada com o dispositivo legal, o qual só prevê a indenização pelo dano causado a outrem, não abarca a responsabilidade pelo dano causado a si mesmo, nada obstante a hipótese de autolesão estar incluída na fórmula neminem lcedere e também ser causa de desequilíbrio social, demonstrando toda a dificuldade para se conceituar o fenômeno. É por isso que Josserand, tomando a responsabilidade em seu sentido mais amplo, "considera responsável aquele que em definitivo suporta um dano" ${ }^{\prime 2}$.

O fato de não existir regra impondo obrigação de ressarcir o dano que foi causado a si mesmo, ao arcar com as conseqüências da conduta lesiva, será o causador do dano por elas responsável, só não restando caracterizado o dever de reparação, pelo fato de confundirem-se, no mesmo patrimônio, crédito pela reparação e a respectiva obrigação. ${ }^{83}$

\footnotetext{
${ }^{80}$ DIAS, José de Aguiar. op. cit., p. 14.

${ }^{81}$ DINIZ, Maria Helena. op. cit., p. 34.

${ }^{82}$ DIAS, José de Aguiar. op. cit., p. 13.

${ }^{83}$ Id. Ibid., p. 13-14.
} 
O dispositivo legal não estabelece hipótese de isenção de responsabilidade; o que existe é a irreparabilidade. ${ }^{84}$

Concluímos, assim, que, se a autolesão se processar em patrimônios diversos, haverá possibilidade de pedido de indenização.

Temos no suicídio o exemplo paradigmático. ${ }^{85}$ Autolesão por excelência, o suicídio evoca, desde sempre, uma noção de irresponsabilidade baseada no aspecto doloso do evento danoso. Mas, em hipóteses especialíssimas, se o suicídio ligar-se a uma causa anterior determinante da autolesão, como o caso de uma patologia ou de estresse relacionado com o trabalho, o pedido de indenização poderá, em tese, ser aviado. ${ }^{86}$

Outros autores fundamentam a responsabilidade no princípio da garantia e restringem o seu conceito à finalidade do instituto, como se infere da lição de Caio Mário:

A responsabilidade civil consiste na efetivação da reparabilidade abstrata do dano em relação a um sujeito passivo da relação jurídica que se forma. Reparação e sujeito passivo compõem o binômio responsabilidade civil, que então se enuncia como o princípio que subordina a reparação à sua incidência na pessoa do causador do dano. ${ }^{87}$

Aguiar Dias argumenta que a noção de garantia revela-se uma forma para apartar a responsabilidade da tradicional noção de culpa, asseverando que a idéia de obrigação é a que mais se aproxima da definição de responsabilidade ${ }^{88}$.

Diante do acima exposto, pela sua amplitude e dificuldade de fixação dos principais aspectos da responsabilidade civil, sendo recorrente a idéia da reparação do dano como materialização do princípio da garantia, destaca-se a definição proposta por Josserand, acatada pela maior parte da doutrina e à qual nos filiamos.

\footnotetext{
${ }^{84}$ LYRA, Afrânio. Responsabilidade civil. 2. ed. São Paulo: Vellenich, 1979. p. 36-37.

${ }^{85}$ ALONSO OLEA, Manoel; TORTUERO PLAZA, José Luiz. Instituciones de seguridad social. 13. ed. Madrid: Civitas, 1992. p. 78-79.

${ }^{86}$ LYRA, Afrânio. op. cit., p. 35.

${ }^{87}$ PEREIRA, Caio Mário da Silva. Responsabilidade civil. Rio de Janeiro: Editora Forense, 1998. p. 11.

${ }^{88}$ DIAS, José de Aguiar. op. cit., p. 3.
} 


\section{Natureza jurídica}

Definido o instituto, há a necessidade de fixar sua natureza jurídica, ou seja, verificar, por seus elementos e características, como é o mesmo classificado no ordenamento jurídico.

Discute-se na doutrina se a responsabilidade civil é sanção ou pena. A idéia não é desprovida de importância. Como já exposto, a responsabilidade civil não era destacada da responsabilidade penal, e a imposição do ressarcimento, na sua origem, sempre teve caráter penal. A distinção entre uma e outra natureza, mesmo para os que defendem a "pena privada" baseada no grau de culpa do agente causador do dano, exige uma perfeita delimitação do que é devido a título de ressarcimento e do que é imposto a título de pena.

No entanto, mesmo com a separação entre o delito e a reparação, a teoria moderna sobre responsabilidade civil manteve-se presa à idéia de fundamentar a reparação no delito, ainda que a hipótese fosse de responsabilidade sem delito, quando, então, teria este de ser imaginado. ${ }^{89}$

Aguiar Dias diz que isso decorre da confusão entre o significado do termo responsabilidade e do de culpabilidade, o que dificulta a identificação da natureza do instituto, advertindo:

De início, como fazem os irmãos Mazeaud, ponhamos em relevo as definições dos que confundem a culpa com o próprio dano e com o laço de causalidade, o que importa em negar-lhe a necessidade. ${ }^{90}$

O mesmo autor, citando Gaston Morin (La loi et le contrat - La décadence de leur souveraineté, Paris, 1927, p. 292 e seguintes), deixa claro que nem mesmo a teoria do risco está infensa a tais artifícios para preenchimento do citado requisito, propondo que o problema seja estudado focando-se quem deve reparar o dano e não quem é responsável. ${ }^{91}$

\footnotetext{
${ }^{89}$ DIAS, José de Aguiar. op. cit., p. 49.

${ }^{90}$ LIMA, Alvino. op. cit., p. 46.

${ }^{91}$ DIAS, José de Aguiar. op. cit., p. 49.
} 
Pablo Stolze Gagliano e Rodolfo Pamplona Filho defendem que a sanção é gênero da qual a pena é espécie e, como conseqüência lógico-jurídica da prática de um ato ilícito, a natureza jurídica da responsabilidade civil ou criminal somente pode ser sancionadora. $^{92}$

No mesmo sentido é a conclusão a que chega Maria Helena Diniz ${ }^{93}$, baseada nas lições de Goffredo Telles Júnior sobre as normas relativas às ações proibidas que autorizam os lesados a reagir exigindo a reposição das coisas ao estado anterior ao da prática da ação proibida ou a exigir a reparação do dano sofrido. ${ }^{94}$

Sublinhe-se que qualquer regra, mesmo as morais, tem a sanção como vocação imanente, tornando imprecisa a classificação da responsabilidade civil como sancionatória.

Miguel Reale, em seu trabalho de diferenciação da sanção moral da sanção jurídica, escreve que sanção é todo e qualquer processo de garantia daquilo que se determina em uma regra, e o que caracteriza a sanção jurídica é a sua predeterminação e organização pela sociedade. ${ }^{95}$

Assim, verifica-se que as sanções da norma jurídica são de várias espécies e, segundo Paulo Dourado de Gusmão, podem ser reunidas em seis categorias: repressivas, preventivas, executivas, restitutivas, rescisórias e extintivas, explicando, a propósito da sanção restitutiva, que:

As sanções restitutivas restabelecem o statu quo ante, como é o caso, no direito civil, das "perdas e danos" (reparação do dano), restabelecendo, pela indenização o patrimônio lesado no estado anterior ao dano, da restituição da coisa furtada ou da indevidamente apropriada, da recuperação da posse, enquanto no direito processual, do pagamento das custas e de honorários de advogado, e no direito fiscal, do confisco de bens etc. ${ }^{96}$

\footnotetext{
${ }^{92}$ GAGLIANO, Pablo Stolze; PAMPLONA FILHO, Rodolfo. op. cit., p. 19-20.

${ }^{93}$ DINIZ, Maria Helena. op. cit., p. 8.

${ }^{94}$ TELLES JR, Goffredo. O direito quântico. 5. ed. São Paulo, Max Limonad, 1980. p. 347.

${ }^{95}$ REALE, Miguel. Lições preliminares de direito. 27. ed. São Paulo: Saraiva, 2002. p. 74-75.

${ }^{96} \mathrm{GUSMÃO}$, Paulo Dourado. Introdução ao estudo do direito. 42. ed. Rio de Janeiro: Forense, 2010. p. 85-86.
} 
No caso da responsabilidade civil, as conseqüências da imputação civil estabelecem a natureza restitutiva (compensatória e/ou reparatória) do fenômeno jurídico, como subespécie da sanção jurídica.

Por sua clareza, a noção da natureza restitutiva da responsabilidade civil que é oferecida por Teresa Ancona Lopez, merece ser aqui transcrita:

Ora, a indenização é sempre um sucedâneo do bem ou da perda que o dano-evento causou, seja material, seja moral. Evidentemente, mesmo nas perdas materiais é impossível, a não ser na responsabilidade contratual, a reparação integral. Essa situação é muito pior no caso de danos à saúde, aos sentimentos, à integridade física, à vida. Nesses casos, nem se pode falar em indenização, e sim em satisfação compensatória para tentar minorar os sofrimentos e humilhações com a lesão sofrida. Como é óbvio, essa "satisfação" ou "indenização compensatória" se reduz a uma soma em dinheiro que poderá ajudar a vítima de algum modo. $^{97}$

Vários doutrinadores, especialmente Nelson Nery Júnior e Rosa Maria de Andrade Nery ${ }^{98}$, também defendem a natureza restitutiva da reparação civil, para distinguir a natureza civil da penal, delineando, de forma mais clara, os campos em que se processam.

Fixada a natureza jurídica da responsabilidade, passaremos, na seqüência, a investigar a sua função.

\section{Função da responsabilidade civil}

A doutrina, de forma geral, elege duas funções para a responsabilidade civil: a reparatória e a preventiva.

Informada, dentre outros, pelo princípio da reparação, a função primeira da responsabilidade civil, como já visto acima, é restabelecer o equilíbrio econômico-jurídico

\footnotetext{
${ }^{97}$ LOPEZ, Teresa Ancona. op. cit., p. 77.

${ }^{98}$ NERY JÚNIOR, Nelson; NERY, Rosa Maria de Andrade. Código civil comentado. 4. ed. São Paulo: Ed. Revista dos Tribunais, 2006. p.608.
} 
abalado pelo dano, reconduzindo-se o prejudicado ao estado anterior à lesão ou, não sendo isso possível, indenizando-o pelo valor correspondente.

Esse escopo primeiro da responsabilidade civil vem sustentado nas idéias de justiça e solidariedade, eleitas objetivos fundamentais da República, conforme dicção do artigo $3^{\circ}$, inciso I, da Constituição Federal de 1988.

Ao lado dessa finalidade reparatória, a concepção de responsabilidade civil evoluiu com a sociedade e dela foram extraídas outras importantes funções, sobressaindo, dentre elas, como reflexo automático da reparação, a sua função preventiva.

Temos, com Teresa Ancona Lopez, que a sociedade contemporânea anseia mais por prevenção de acidentes do que por indenizações. ${ }^{99}$ Os riscos a que os indivíduos estão submetidos são tantos que a tão-só possibilidade de danos gera insegurança, e isso, em uma análise mais profunda, significa rompimento do equilíbrio social.

Como função preventiva, a indenização imposta pelo Poder Judiciário revela-se medida socioeducativa profilática que também é dirigida aos demais membros integrantes sociedade, como forma de desmotivação social da conduta lesiva.

Para reforçar essa idéia de prevenção, considerando insuficiente a desmotivação provocada pela reparação, alguns juristas, com finalidade punitiva do réu e intuito de gerar efetivo temor em todos os cidadãos, propuseram agregar, à indenização devida pelo prejuízo, medidas econômicas mais gravosas, como fator de desestímulo da conduta lesiva. É a teoria da responsabilidade civil como pena privada, idealizada por Boris Stark, acolhida pelos Estados Unidos da América e Inglaterra sob o título punitive damages ou exemplary damages. ${ }^{100}$

Naqueles países, a aplicação do instituto é restrita aos casos em que o réu tenha agido com dolo e, em alguns estados americanos, com culpa grave, sempre que tenha ele se locupletado da vulnerabilidade econômica da vítima. ${ }^{101}$

No Brasil, a utilização do binômio reparação-desestímulo é uma tendência doutrinária e jurisprudencial para as indenizações por danos morais e, conquanto a parcela

\footnotetext{
${ }^{99}$ LOPEZ, Teresa Ancona. op. cit., p. 77.

${ }^{100}$ Id. Ibid., p. 80.

${ }^{101}$ Id. Ibid., p. 82.
} 
punitiva seja baseada na conduta do autor da lesão, não são exigidos os requisitos previstos no direito anglo-saxão.

Com base nos trabalhos de Philippe Le Tourneau e Loïc Cadiet, Teresa Ancona Lopez reconhece que o mecanismo securitário promoveu o enfraquecimento da função preventiva da indenização civil, no sentido de desestímulo de realização de danos, mas identifica que essa função, influenciada pelo "princípio da precaução", tem se desenvolvido por outros caminhos, frisando que:

É necessário que se ponha em prática o princípio da prevenção como instrumento anterior ao dano, e não como conseqüência desse (função automática da indenização), quando o seguro já "reparou" os prejuízos sofridos. ${ }^{102}$

Frente ao princípio da precaução, que tem por objeto os riscos "incertos" ou "hipotéticos", e tendo-se em vista a "sociedade do risco", que reclama mecanismos de equilíbrio e segurança, vaticina a autora acima citada que, tanto no campo individual quanto no coletivo, o presente século assistirá ao desenvolvimento dos "princípios da prevenção e da precaução fundamentados na ética da prudência e no princípio da solidariedade social e segurança geral, hoje positivados" 103 .

A propósito da responsabilidade sem dano, fazendo referência a Catherine Thibierge (Libres propos sur l'évolution du droit de la responsabilité. In: Revue Trimestrielle de Droit Civil, $\mathrm{n}^{\mathrm{o}}$ 3, julho/setembro 1999, Paris, p. 561-584), Teresa Ancona Lopez constata que a evolução da sociedade tem criado tipos de danos denominados, pela doutrina francesa, de "danos graves e irreversíveis", para os quais não há reparação possível, forçando, dessa forma, a flexibilização da responsabilidade civil e admitindo presunções de causalidade baseadas na probabilidade e na estatística. Propõe ela a denominação "dano de risco" como materialização da função de prevenção e de precaução de eventos danosos e cita, como exemplo, os danos em série decorrentes do consumo em massa e que prejudicam uma determinada categoria de pessoas que podem não ter participado do contrato de adesão. ${ }^{104}$

\footnotetext{
${ }^{102}$ LOPEZ, Teresa Ancona. op. cit., p. 79.

${ }^{103}$ Id. Ibid., p. 87.

${ }^{104}$ Op. cit., p. 133-135.
} 
Essa postura pró-ativa da lei é outra função que a doutrina vislumbrou no amplo campo da responsabilidade civil, decerto ainda um pouco nebulosa, mas que o engenho humano dará conta de desenvolver e, quando isso ocorrer, representará uma revolução sem precedentes para a matéria, sendo oportuna a manifestação de Giselda Maria F. Novaes Hironaka:

Não resta dúvida, mesmo, de que há uma extraordinária urgência em se construir, na ambiência do direito positivo da responsabilidade civil, uma regra tal que seja suficientemente geral e abrangente, capaz de recepcionar as hipóteses já conhecidas de danos injustos que devam ser reparados ou indenizados, assim como que seja capaz de recepcionar, também, as hipóteses de outras ocorrências danosas relacionadas a um porvir prejudicial. ${ }^{105}$

Concluímos, assim, que a responsabilidade civil, ao lado de suas principais finalidades, tem importante função preventiva que, até hoje, foi pouco explorada, especialmente no viés da precaução.

Encerra-se, aqui, a primeira parte deste trabalho. No próximo capítulo serão abordadas as espécies de responsabilidade civil, apresentando-se um resumo sobre as teorias explicativas da responsabilidade civil.

${ }^{105}$ HIRONAKA, Giselda Maria Fernandes Novaes. op. cit., p. 353-354. 


\section{ESPÉCIES DE RESPONSABILIDADE CIVIL E TEORIAS APLICÁVEIS AO DIREITO DO TRABALHO}

\section{Espécies de responsabilidade civil}

A responsabilidade civil ainda pode ser dividida em diferentes espécies; tomando-se a origem ou o fato gerador, a responsabilidade civil classifica-se em contratual ou extracontratual. Se analisada da perspectiva do elemento subjetivo do dever de indenizar, será subjetiva ou objetiva.

\subsection{Responsabilidade contratual e responsabilidade extracontratual}

A responsabilidade civil, como visto até agora, é deflagrada pelo prejuízo decorrente da inexecução de um dever. Esse dever pode decorrer de um contrato ou ser imposto por lei. Se o prejuízo decorre da inexecução de uma relação obrigacional, fala-se em responsabilidade contratual ou relativa; se decorre da violação de um dever legal, sem uma relação jurídica-base, a responsabilidade é denominada extracontratual, aquiliana ou absoluta.

Sob o argumento de que tanto na responsabilidade contratual quanto na extracontratual há a violação de um dever jurídico preexistente, os defensores da corrente monista, também denominada unitária, afirmam que, nas duas modalidades de responsabilidade civil, os efeitos são os mesmos, não vislumbrando eles a dicotomia apontada. $^{106}$

Sílvio de Salvo Venosa traz importante contribuição para o debate, afirmando que:

${ }^{106}$ CAVALIERI FILHO, Sérgio. op. cit., p. 16. 
Há tendência de ser estendida a responsabilidade contratual a terceiros atingidos por um negócio jurídico originário. Essa extensão possui evidentes reflexos no montante e nos limites da indenização, geralmente balizados pelo contrato. ${ }^{107}$

Em contraposição à corrente unitária, a lição de Pontes de Miranda é no sentido da possibilidade de concorrência das responsabilidades, ou seja, nada impede que coexistam lado a lado e que cada qual produza os seus respectivos efeitos. ${ }^{108}$

Arnaldo Rizzardo, também em defesa da diferenciação da responsabilidade contratual da extracontratual, coloca que:

Embora a existência de aspectos comuns, não se olvidam os contornos privativos e especiais, e inclusive com regras próprias de cada tipo. Se contratual a responsabilidade, incide, dentre outras normas características, a exceção do contrato não cumprido - exceptio non adimpleti contractus, estabelecida no art. 476 (art. 1.092 do Código revogado), e a onerosidade excessiva, prevista no art. 478, sem regra equivalente no código revogado. ${ }^{109}$

De fato, a teoria unitária tem um alcance muito reduzido e procura igualar situações que, no mais das vezes, submetem-se a diferentes regimes normativos. Essa é uma preocupação de muitos autores, conforme observado acima por Pontes de Miranda e Arnaldo Rizzardo, e é uma separação que interessa especialmente ao Direito do Trabalho. Pela teoria monista, em sua versão mais radical, qualquer prejuízo sofrido no âmbito da relação de emprego ganharia contornos contratuais e, dessa forma, teria de ser classificado como crédito trabalhista. Essa concepção tem importantes conseqüências para a análise da questão das indenizações no âmbito do contrato de emprego, a começar por decidir qual o regime de prescrição aplicável à espécie.

\footnotetext{
${ }^{107}$ VENOSA, Sílvio de Salvo. op. cit., p. 21.

${ }^{108}$ MIRANDA, Francisco Cavalcanti Pontes de. op. cit., p. 87.

${ }^{109}$ RIZZARDO, Arnaldo. op. cit., p. 42.
} 


\subsection{Responsabilidade civil subjetiva e responsabilidade civil objetiva}

O direito brasileiro, em tese, manteve a culpa como fundamento geral da responsabilidade civil, a teor do que dispõe o artigo 186 do Código Civil de 2002:

Aquele que, por ação ou omissão voluntária, negligência ou imprudência, violar direito e causar dano a outrem, ainda que exclusivamente moral, comete ato ilícito.

O termo culpa é empregado pelo Código Civil de 2002 em sentido amplo e é o principal pressuposto da responsabilidade subjetiva, compreendendo a noção de dolo e a de culpa em sentido estrito, caracterizada pela negligência, imperícia ou imprudência.

De acordo com Alvino Lima, a culpa civil é um fenômeno complexo que reúne um elemento objetivo, consistente na lesão ou atentado ao direito de outrem, e um elemento subjetivo, com foco na previsão ou possibilidade de previsão do atentado ao direito de outrem, declarando:

Tal conceito de culpa ultrapassa os limites do sentido técnico desse elemento da responsabilidade civil; se, em sentido amplo, genérico, podemos dizer que a culpa é a lesão imputável do direito de terceiro, ou qualquer fato ou violação de um dever jurídico, no sentido restrito, como elemento da responsabilidade civil, a culpa é apenas, como veremos oportunamente, um erro de conduta, um desvio da normalidade no agir ou abster-se. ${ }^{110}$

Quando ambos os elementos se integram, exsurge a responsabilidade civil. Contudo, a vítima só obterá reparação se provar a culpa do causador do dano, o prejuízo e o nexo de causalidade. Ausentes quaisquer desses elementos, o fato danoso deixa de ter significação jurídica. ${ }^{111}$

${ }^{110}$ LIMA, Alvino. op. cit., p. 52.

${ }^{111}$ Id. Ibid. 
Também deixa o lesado de ter direito à reparação nas hipóteses em que a conduta lesiva não viola dever jurídico, como é o caso das excludentes da responsabilidade civil (culpa exclusiva da vítima, força maior, caso fortuito, exercício regular de um direito, legítima defesa ou estado de necessidade).

Essa concepção clássica da responsabilidade civil, no entanto, não possuía generalidade suficiente para amparar todas as situações novas que surgiram com o desenvolvimento industrial, o maquinismo, a introdução de novas tecnologias, o crescimento populacional etc., ensejando, como já estudado neste trabalho, movimentos no sentido da objetivação da culpa. Essa tendência fez surgir a responsabilidade objetiva baseada na teoria do risco profissional, relacionado a um seguro social ou a um seguro privado obrigatório, bem como a responsabilidade objetiva baseada no risco criado, adotada pela lei brasileira em vários diplomas legais e especialmente no parágrafo único do art. 927 do Código Civil, com a seguinte redação: "haverá obrigação de reparar o dano, independentemente de culpa, nos casos especificados em lei, ou quando a atividade normalmente desenvolvida pelo autor do dano implicar, por sua natureza, risco para os direitos de outrem".

Nesses casos de responsabilidade sem culpa, não é examinada a conduta do agente causador do dano. Para que haja dever de indenizar basta a prova do dano e do nexo etiológico.

\section{Requisitos da responsabilidade civil}

A fixação dos pressupostos de configuração da responsabilidade civil, no entanto, traduz-se em outro grande debate na doutrina e na jurisprudência, conforme lição de Maria Helena Diniz:

Bastante difícil é a caracterização dos pressupostos necessários à configuração da responsabilidade civil, ante a grande imprecisão doutrinária a respeito. Deveras, díspares são as conclusões dos juristas sobre os elementos imprescindíveis à caracterização da responsabilidade civil, pois, p. ex., Marty e Raynaud apontam o "fato danoso", o "prejuízo" e o "liame entre eles" com a "estrutura comum" da responsabilidade; Savatier apresenta a culpa e a imputabilidade como 
seus pressupostos; Trabucchi exige o fato danoso, o dano e a antijuridicidade ou culpabilidade. ${ }^{112}$

A doutrina estabelece como elementos essenciais, tanto para caracterização da responsabilidade contratual como da aquiliana, a conduta humana, comissiva ou omissiva, a ocorrência de um dano e o nexo de causalidade entre o dano e a conduta.

\subsection{Conduta humana}

Sílvio Rodrigues diz que a responsabilidade pode decorrer de ação ou de omissão do próprio causador do dano, de ato danoso de terceiro sob a responsabilidade do agente, bem como de danos causados por coisas sob a sua guarda. ${ }^{113}$

Enquanto no dolo a intenção de lesar é voluntária, na culpa há conduta desintencional, como explica Cavalieri Filho:

\footnotetext{
Na culpa não há intenção, mas há vontade; não há conduta intencional, mas tencional. A vontade não se dirige a um fim determinado, como no dolo, mas se dirige à conduta. A conduta é voluntária; involuntário é o resultado. ${ }^{114}$
}

A responsabilidade de indenizar, por sua vez, pode decorrer de ato ilícito, fundamentada na culpa, ou de ato lícito ou ilícito, fundamentada no risco. Nada obstante isso, a responsabilidade civil fundada na culpa é a regra geral. Se a conduta contrariar dever geral previsto no ordenamento jurídico ou se representar o descumprimento de obrigação contratual, haverá obrigação de indenizar. ${ }^{115}$ Sem embargo, excepcionalmente o dever de reparar o dano também pode decorrer de uma conduta lícita, com fundamento em uma determinação legal ou informada na idéia do risco ${ }^{116}$. Neste caso, não se investiga o

\footnotetext{
${ }^{112}$ DINIZ, Maria Helena. op. cit., p. 36.

${ }^{113}$ RODRIGUES, Silvio. op. cit., p. 15.

${ }^{114}$ CAVALIERI FILHO, Sérgio. op. cit., p. 35.

${ }^{115}$ DINIZ, Maria Helena. op. cit., p. 37.

${ }^{116}$ RODRIGUES, Silvio. op. cit., p. 17.
} 
ânimo do causador do dano. O dever de reparar o dano, no caso de responsabilidade objetiva, decorre do fato e não da conduta.

\subsection{Dano}

O segundo elemento de configuração da responsabilidade civil é a verificação de um dano. Segundo Sílvio Rodrigues, não se propõe a questão da responsabilidade se não houver um dano, asseverando que o ato ilícito só repercute na órbita do direito civil se causar prejuízo a alguém. ${ }^{117}$ Portanto, dano equivale a um prejuízo certo e atual, excluindose os danos meramente hipotéticos ${ }^{118}$.

Essa é uma afirmação clássica e, se tomada de forma descuidada, pode dificultar a visualização do dano exclusivamente moral. Como anota Arnaldo Rizzardo, no dano puramente moral não há diminuição do patrimônio do lesado, apresentando-se como aquele mal ou dano que atinge valores eminentemente espirituais ou morais, como a honra, a paz, a liberdade física, a tranqüilidade de espírito, a reputação, a beleza etc. ${ }^{119}$

Se houver qualquer repercussão sensível do dano (prejuízo), não há dúvida que, ao lado do dano moral, estaremos diante de um dano material. Rizzardo dá conta dessa confusão, apontando vários exemplos de prejuízos morais que, na verdade, apresentam-se como danos patrimoniais presumidos. ${ }^{120}$

Nesse contexto, o Código Civil de 1916, que no seu artigo 159 falava em violação de direito ou dano, parece ser mais claro que o artigo 186 do Código Civil de 2002, que caracteriza o ato ilícito pela violação do direito e ocorrência de dano, insinuando, a partícula aditiva, que a simples violação do direito sem a ocorrência de um dano, afastaria o dever de indenizar.

\footnotetext{
${ }^{117}$ RODRIGUES, Silvio. op. cit., p. 18.

${ }^{118} \mathrm{~A}$ propósito da responsabilidade sem dano, tem a doutrina admitido que a cláusula geral de responsabilidade civil também abriga a idéia da reparação do dano potencial. Nesse sentido podem ser consultados: HIRONAKA, Giselda Maria Fernandes Novaes. op. cit.; LOPEZ, Teresa Ancona. op. cit.

${ }^{119}$ RIZZARDO, Arnaldo. op. cit., p. 248.

${ }^{120}$ Id. Ibid., p. 247 . O art. 953 e seu parágrafo único da lei substantiva civil sugerem uma das hipóteses bastante evidentes de ligação de indenização por dano moral ao prejuízo econômico... Como é difícil chegar ao prejuízo patrimonial, vem estabelecido o critério capaz de apurar o montante. Mesmo assim, no fundo, embora a ofensa seja moral, há uma dimensão patrimonial.
} 
Em seu Tratado de Direito Privado, Pontes de Miranda divide o dano moral em causativo ou acausativo, asseverando que:

Se o dano foi só moral, porque a pessoa que o sofreu com ele não deixou de ganhar ou a pessoa só vivia de rendas, e não houve diminuição de saúde, o dano foi acausativo. Tem de ser avaliado em si mesmo e aí está a espécie de mais difícil reparação. ${ }^{121}$

Conclui-se, assim, que o dano moral é indenizável pela simples violação de um direito, não sendo necessário o prejuízo ou que venha acompanhado de uma repercussão sensível de qualquer tipo. Trata-se de dano in re ipsa.

Analisando essa questão, Cavalieri Filho coloca que:

Nessa perspectiva, o dano moral não está necessariamente vinculado a alguma reação psíquica da vítima. Pode haver ofensa à dignidade da pessoa humana sem dor, sem vexame e sofrimento sem violação da dignidade. Dor, vexame, sofrimento e humilhação podem ser conseqüências, e não causas. ${ }^{122}$

A leitura do dano moral como aquele decorrente da simples violação de um direito, isto é, sem necessidade de verificação de prejuízo, acolhe situações em que a vítima não está sujeita a reação psíquica, como o caso das pessoas jurídicas, das pessoas físicas em estado de coma, dos loucos etc.

\subsection{Relação de causalidade entre a ação e o dano}

Por fim, pelo terceiro requisito mencionado, a responsabilidade civil só terá lugar se estabelecida relação de causa e efeito entre a conduta lesiva e o dano.

\footnotetext{
${ }^{121}$ MIRANDA, Francisco Cavalcanti Pontes de. op. cit., p. 231.

${ }^{122}$ CAVALIERI FILHO, Sérgio. op. cit., p. 80.
} 
Não basta, assim, que o agente tenha praticado uma conduta ilícita ou que a vítima tenha sofrido um dano. Para que haja o dever de indenizar, a conduta tem de ser a causa do evento danoso. ${ }^{123}$

O tema não é meramente acadêmico. Existe uma real preocupação dos juristas com a perfeita identificação da causa que acarretou o dano, uma vez que as conseqüências jurídicas do dever de reparar o dano variam conforme a teoria adotada, especialmente na responsabilidade objetiva, em que o dano e a causa são os elementos que impõem a obrigação pela reparação do dano.

A doutrina, dentre as várias existentes, destaca três teorias que abordam a questão relacionada ao nexo causal: a teoria da conditio sine qua non, a teoria da causalidade adequada e a teoria dos danos diretos e imediatos.

\subsubsection{Teoria da conditio sine qua non}

Pela teoria da conditio sine qua non, também chamada de teoria da equivalência dos antecedentes ou de teoria da equivalência das condições, qualquer fator que tenha concorrido para o evento danoso é considerado condição deste, sem importar qual foi o mais ou menos eficaz. Descobre-se se a condição é causa através de um processo hipotético de eliminação da condição. Se mentalmente eliminada o resultado desaparecer, a condição é causa; se permanecer, esse fato não é determinante do dano e, portanto, não é causa. $^{124}$

Essa teoria foi concebida para aplicação no direito penal. Contudo, a transposição para o direito civil é muito criticada, porque permitiria uma regressão infinita do nexo causal.

\footnotetext{
${ }^{123}$ DINIZ, Maria Helena. op. cit., p. 38.

${ }^{124}$ CAVALIERI FILHO, Sérgio. op. cit., p. 47.
} 


\subsubsection{Teoria da causalidade adequada}

A teoria da causalidade adequada, criada por von Kries, considera causa o fato antecedente necessário e adequado à produção do resultado; procura identificar qual a causa determinante do dano. Ao contrário da teoria da conditio sine qua non, a teoria da causalidade adequada faz distinção entre causa e condição, bem assim entre os antecedentes que tiveram maior ou menor relevância, usando, porém, do mesmo processo hipotético de eliminação de condição. ${ }^{125}$ Considera-se causa a condição predominante que gerou o dano.

\subsubsection{Teoria do dano direto e imediato}

Idealizada por Agostinho Alvim em sua obra intitulada "Da inexecução das obrigações e suas conseqüências", a teoria do dano direto e imediato, também denominada da interrupção do nexo causal ou da causalidade necessária, considera causa o fato antecedente exclusivo do dano, concluindo seu idealizador “que é indenizável todo dano que se filia a uma causa, ainda que remota, desde que ela lhe seja causa necessária por não existir outra que explique o mesmo dano"126.

\subsubsection{Teoria adotada pelo Código Civil brasileiro}

A terceira corrente explicativa do nexo causal, chamada de teoria dos danos diretos e imediatos, congrega as duas anteriores e, segundo Rizzardo, essa foi a teoria adotada pelo legislador brasileiro, escrevendo:

\footnotetext{
${ }^{125}$ CAVALIERI FILHO, Sérgio. op. cit., p. 48.

${ }^{126}$ ALVIM, Agostinho. Da inexecução das obrigações e suas conseqüências. Rio de Janeiro; São Paulo: Ed. Jurídica e Universitária, 1965. p. 339.
} 
O Código Civil brasileiro adotou a causa do dano direto e imediato, com amparo no art. 403 (art. 1.060 do Código de 1916), preceituando: "Ainda que a inexecução resulte de dolo do devedor, as perdas e danos só incluem os prejuízos efetivos e os lucros cessantes por efeito dela direto e imediato, sem prejuízo do disposto na lei processual. ${ }^{127}$

Conquanto a expressão "efeito direto e imediato" autorize essa conclusão, outros autores, dentre eles Aguiar Dias e Martinho Garcez Neto, contrariamente ao entendimento acima transcrito, asseveram que no direito civil brasileiro prevalece a teoria da causalidade adequada. ${ }^{128}$

As teorias defendidas, no entanto, não se mostram de todo contrárias. A primeira, por sua falta de limitação, enseja situações que destoam da razoabilidade, mas as duas últimas são muito semelhantes. De fato, identificar as causas diretas e imediatas do dano não quer dizer outra coisa senão buscar, na cadeia de fatos que produziram o evento danoso, a condição ou causa determinante deste.

Sem desmerecer as teorias existentes, concluímos, com Sílvio de Salvo $\operatorname{Venosa}^{129}$, que a questão não prejudica as decisões nos casos concretos, já que cabe ao juiz decidir, com base nas provas dos autos, se há relação de causalidade entre a conduta do agente e o dano, servindo-se das teorias para orientar o raciocínio que fundamenta a sua decisão.

\subsection{Excludentes da responsabilidade civil}

Ainda que presentes os elementos essenciais de configuração da responsabilidade civil, existem hipóteses em que a conduta, embora danosa, não viola dever jurídico. ${ }^{130}$ São denominadas causas de exclusão de ilicitude.

Também conhecido como rompimento do nexo causal, exclui a responsabilidade a culpa exclusiva da vítima, o fato de terceiro, o caso fortuito e a força

\footnotetext{
${ }^{127}$ RIZZARDO, Arnaldo. op. cit., p. 76.

${ }^{128}$ CAVALIERI FILHO, Sérgio. op. cit., p. 49-50.

${ }^{129}$ VENOSA, Sílvio de Salvo. op. cit., p. 48.

${ }^{130}$ CAVALIERI FILHO, Sérgio. op. cit., p. 18.
} 
maior. No âmbito do contrato, a exclusão da responsabilidade pode ser convencionada pelas partes, por meio de cláusula de não indenizar. ${ }^{131}$

Igualmente, não são considerados ilícitos os atos praticados no exercício regular de um direito, em legítima defesa ou em estado de necessidade.

Discute-se, na doutrina, se o risco de desenvolvimento é causa de exclusão do dever de reparar. Para Cavalieri Filho, trata-se de "risco integrante da atividade do fornecedor, pelo que não-exonerativo da sua responsabilidade". ${ }^{132}$ Teresa Ancona Lopez, entretanto, não vê a questão com tanta rigidez, apresentando várias hipóteses que, no futuro, poderão ser encaradas como risco de desenvolvimento, para excluir a indenização por eventuais danos, como é o caso da telefonia móvel, por danos ainda desconhecidos, que possam decorrer do uso do celular, concluindo que:

[...] chegamos à conclusão que admitir o risco de desenvolvimento como excludente não põe em risco a segurança dos produtos. A segurança é obrigatória sempre e, no caso, o defeito somente apareceu depois de certo prazo do produto no mercado. Quando foi lançado apresentava a segurança esperada segundo o state of the art. A segurança é requisito prévio e a excludente por risco somente se dá a posteriori do dano. $\mathrm{O}$ risco de desenvolvimento somente vem demonstrar que o risco está em toda parte na sociedade contemporânea. ${ }^{133}$

\section{Teorias que fundamentam a responsabilidade civil}

São muitas as teorias que fundamentam o direito à reparação dos danos, as quais, no mais das vezes, relacionam-se com o prejuízo sofrido pelo ofendido. ${ }^{134}$ Contudo, as teses defendidas estabelecem concepções e trilham caminhos que logo se vêem superados ante o frenético desenvolvimento da sociedade, inviabilizando a construção de uma teoria unitária.

\footnotetext{
${ }^{131}$ VENOSA, Sílvio de Salvo. op. cit., p. 48.

${ }^{132}$ Id. Ibid., p. 178.

${ }^{133}$ LOPEZ, Teresa Ancona. op. cit., p. 204.

${ }^{134}$ BITBOL, Aida S. Accidentes de trabajo y enfermidades reparables. Buenos Aires: Bibliográfica Omeba, 1964. p. 22.
} 
Como já mencionado, a teoria da culpa vige, em todas as legislações, como princípio fundamental. $^{135}$

Mas o desenvolvimento da sociedade e os progressos científicos, tecnológicos e sociais por ela experimentados fizeram surgir casos concretos que refugiam ao âmbito da culpa, o que levou a jurisprudência a ampliar o seu conceito mediante a adoção de novas técnicas doutrinárias para a caracterização do dever de indenizar, culminando com o desenvolvimento da teoria do risco.

Discorrendo sobre o tema, Alvino Lima coloca que:

Vários foram os processos técnicos postos em jogo para atender à praticabilidade da responsabilidade: admissão fácil da existência da culpa pela aplicação da teoria do abuso do direito e da culpa negativa; o reconhecimento de presunções de culpa; aceitação da teoria do risco; $[\ldots]^{136}$

Empreenderemos, a seguir, o estudo de como se deu a evolução da responsabilidade civil extracontratual, consistindo num dos principais pontos para a compreensão deste trabalho, especialmente no que diz respeito aos fundamentos que levaram ao alargamento do dever de indenizar.

\subsection{Responsabilidade civil fundada na culpa}

A teoria clássica da responsabilidade civil fundada na culpa, idealizada no direito romano e aperfeiçoada no direito francês, ainda é a inspiração de todas as legislações modernas, nada obstante o inegável avanço da responsabilidade objetiva. Continua, assim, a ser o fundamento básico da responsabilidade aquiliana.

Ao lado dos requisitos de configuração da responsabilidade civil já expostos, a teoria da responsabilidade subjetiva exige a demonstração da conduta culposa.

${ }^{135}$ LIMA, Alvino. op. cit., p. 39.

${ }^{136}$ Id. Ibid., p. 40. 
Em sentido amplo, a culpa civil abrange o dolo, que é a conduta intencional, e a culpa em sentido estrito, quando o dano decorrer de negligência, imprudência ou imperícia do causador do dano.

O conceito de culpa, porém, é outro grande problema da responsabilidade civil, e, dependendo da forma como é definida, surgem conseqüências quanto à fixação da responsabilidade. ${ }^{137}$ Para Alvino Lima, quando a conduta do agente que causa dano ao direito de outrem não se conforma com a determinação específica e taxativa da lei, a culpa se caracteriza por si mesma. No entanto, se o evento danoso decorre da não observância de obrigação genérica de prudência e diligência, a culpa depende da apreciação do juiz. Essa discricionariedade própria das cláusulas gerais faz surgir o problema de se saber se a conduta do causador do dano deve ser apreciada in concreto, examinando o ânimo psicológico particular do autor do dano, ou in abstracto, diante da conduta normal dos indivíduos em geral. ${ }^{138}$

Alvino Lima, em adesão à teoria objetiva da culpa (in abstracto), adotada pela quase generalidade dos autores, conceitua culpa como "um erro de conduta moralmente imputável ao agente e que não seria cometido por pessoa avisada, em iguais circunstâncias". 139

No mesmo sentido, Aguiar Dias, conclui:

\begin{abstract}
A boa solução é, pois, colocar o tipo de comparação na situação onde se encontrava o agente, e pesquisar como teria reagido em face das circunstâncias internas. Agindo conforme a reação tipo-padrão, em momento idêntico, o agente terá agido bem. Se se desviar da condutapadrão, nas mesmas circunstâncias externas, incorre em culpa. ${ }^{140}$
\end{abstract}

A concepção clássica da responsabilidade civil, porém, tornou-se insuficiente para dar resposta aos novos casos surgidos com o progresso da humanidade, o que fez com

\footnotetext{
${ }^{137}$ LIMA, Alvino. op. cit., p. 44.

${ }^{138}$ Id. Ibid., p. 56.

${ }^{139}$ Id. Ibid., p. 69.

${ }^{140}$ DIAS, José de Aguiar. Da responsabilidade civil, cit., p. 116.
} 
que a jurisprudência e a doutrina passassem a objetivar o conceito de culpa, sem dispensar, no entanto, a prova da imperícia, da imprudência e da negligência. ${ }^{141}$

Os principais mecanismos de alargamento da concepção de culpa, segundo Alvino Lima ${ }^{142}$, consistiram 1) na admissão, com facilidade, da existência de culpa; 2) no reconhecimento das presunções de culpa e 3) na extensão do próprio conceito de culpa.

No primeiro, informado pelo princípio in lege Aquilia et levissima culpa venit, não se considera a intensidade da culpa e não se vincula à capacidade individual do agente, bastando a culpa mínima para deflagrar o dever de indenizar.

O segundo, visando melhorar a situação processual da vítima, propõe hipóteses legais de inversão do ônus da prova. Na presunção relativa (juris tantum), a culpa está no próprio fato lesivo, cabendo ao autor do dano elidi-la. Na presunção absoluta (juris et de jure) a culpa não pode ser elidida, residindo ela no próprio fato danoso. A noção de culpa se alarga para absorver a noção de risco. Diante desse quadro, Alvino Lima afirma que as presunções absolutas de culpa são a consagração da teoria da responsabilidade objetiva, da responsabilidade sem culpa, uma vez que impede o autor do dano de provar a ausência de culpa, respondendo pelo dano ainda que falsa a presunção. ${ }^{143}$ É oportuno transcrever, aqui, preleção de Alvino Lima:

\begin{abstract}
A teoria da culpa, pela maioria de seus defensores, proclama e defende as presunções juris et de jure da culpa, sustentando que nelas não se sacrifica nem se repudia o princípio básico da teoria subjetiva, porquanto subsiste sempre o elemento da culpabilidade. Entretanto, defensores estrênuos e notáveis da teoria da culpa não se cansam de proclamar, verdadeiramente, que as presunções juris et de jure não passam de um disfarce da teoria objetiva. ${ }^{144}$
\end{abstract}

Resumindo, Cláudio Luiz Bueno de Godoy afirma que "até que se chegasse ao risco, algumas presunções antes reputadas relativas passaram a ser consideradas agora absolutas, ou seja, sem possibilidade de prova do contrário". ${ }^{145}$

\footnotetext{
${ }^{141}$ LIMA, Alvino. op. cit., p. 70.

${ }^{142}$ Id., loc. cit.

${ }^{143}$ Id. Ibid., p. 75.

${ }^{144}$ Id. Ibid., p. 192.

${ }^{145}$ GODOY, Cláudio Luiz Bueno de. Responsabilidade civil pelo risco da atividade: uma cláusula geral no Código Civil de 2002. 2. ed. São Paulo: Saraiva, 2010. p. 79.
} 
Por fim, a extensão do conceito de culpa, com a noção de culpa negativa decorrente da não adoção de cuidados assecuratórios, da falta de dever de cuidado, pelo abuso de direito, até chegar à culpa objetiva, verificada com base no tipo-padrão de conduta, mas ainda exigindo a imputabilidade moral, por dolo (intenção) ou por culpa (negligência, imprudência ou imperícia). ${ }^{146}$

\subsection{Responsabilidade civil fundada no risco}

A partir da introdução das máquinas no processo industrial, da explosão demográfica e do progresso científico e tecnológico, a teoria da responsabilidade civil fundada na culpa, principalmente no campo dos acidentes do trabalho, mostrou-se insuficiente como mecanismo de restabelecimento do equilíbrio social.

Essa nova configuração das relações intersubjetivas desencadeou movimentos no sentido de dissociar o dano da idéia de culpa, surgindo, com Louis Josserand e Raymond Saleilles, a teoria da responsabilidade objetiva, ou doutrina do risco. ${ }^{147}$

Nesse sistema, coloca Caio Mário que, "ao invés da responsabilidade assentar numa relação causal entre o dano e a culpa, simplifica-se nesta outra, entre o fato e o dano (entre le fait et le dommage)". ${ }^{148}$

Carlos Alberto Bittar anota que, fora da noção geral de culpa, esse sistema decorreu da constatação de que muitas atividades, por sua periculosidade, embora legítimas, traziam em si riscos próprios, carreando aos exploradores destas mesmas atividades a responsabilidade pela simples criação e pela introdução de coisas perigosas na sociedade. $^{149}$

Assim, para a corrente objetiva, a responsabilidade decorre diretamente do fato, impondo, em casos expressamente previstos em lei, o dever de reparar o prejuízo verificado, independentemente da comprovação do desvio de conduta.

\footnotetext{
${ }^{146}$ GODOY, Cláudio Luiz Bueno de. op. cit., p. 78.

${ }^{147}$ DIAS, José de Aguiar. op. cit., p. 50.

${ }^{148}$ PEREIRA, Caio Mário da Silva. Direito civil: alguns aspectos da sua evolução, cit., p. 119.

${ }^{149}$ BITTAR, Carlos Alberto. op. cit., p. 97.
} 
Por sua idoneidade científica, a teoria do risco é vista com bons olhos pelos que alertavam para a falsidade do sistema de presunções, dentre eles Aguiar Dias, que a respeito assim se manifestou:

\begin{abstract}
A teoria da responsabilidade objetiva, ou doutrina do risco, tem, pelo menos, o mérito de se inteirar daquele equívoco e, se é passível de crítica, esta por certo não reside na contradição. Corresponde, em termos científicos, à necessidade de resolver casos de danos que pelo menos com acerto técnico não seriam reparados pelo critério clássico da culpa. É visível, a este respeito, o erro das soluções encontradas pelos partidários da doutrina tradicional, e notória a artificialidade de suas construções. ${ }^{150}$
\end{abstract}

Sedimentada a noção de atividade perigosa e o caráter objetivo de seu fundamento, especialmente na doutrina francesa, a responsabilidade sem culpa, que já era prevista em legislações especiais, passou a fazer parte de alguns códigos estrangeiros, especialmente do italiano, vazada na forma de cláusula geral, na qual o risco serve como nexo de imputação, a teor do que dispõe o seu artigo 2.050: chiunque cagiona danno ad altri nello svolgimento di un'attività pericolosa, per sua natura o per la natura dei mezzi adoperati, è tenuto al risarcimento, se non prova di avere adottato tutte le misure idonee a evitare il danno ${ }^{151}{ }^{152}$

O termo risco é, assim, conceito aberto que reclama interpretação. Segundo Giselda Hironaka, tem origem no italiano antigo risicare, que significa "arriscar", "ousar", levando essa importante doutrinadora a afirmar que o risco é uma opção e não um destino. $^{153}$

Tereza Ancona Lopez diz que, em sede de responsabilidade civil, tomado no sentido jurídico, o termo risco não perde o seu caráter de incerteza, com a possibilidade de causar dano a outrem, escrevendo:

[...] foi na responsabilidade civil que a noção de risco tomou impulso. $\mathrm{Na}$ primeira década do século $\mathrm{XX}$, preocupados com a invenção do

\footnotetext{
${ }^{150}$ DIAS, José de Aguiar. op. cit., p. 49.

${ }^{151}$ Proposta de tradução: aquele que causar dano a outrem no desempenho de uma atividade perigosa por sua própria natureza ou pela natureza dos meios empregados ficará obrigado a repará-lo, se não provar ter adotado todas as medidas idôneas para evitar o dano.

${ }^{152}$ GODOY, Cláudio Luiz Bueno de. op. cit., p. 46.

${ }^{153}$ HIRONAKA, Giselda Maria Fernandes Novaes. op. cit., p. 106.
} 
automóvel e das máquinas, perceberam os juristas que a vítima estava enfraquecida, desprotegida caso a culpa continuasse sendo a teoria informadora da responsabilidade civil. Era preciso reverter o ônus da prova. Dá-se a partir daí a evolução da responsabilidade civil e aparece a "teoria do risco" (no singular), que fundamenta a responsabilidade não na culpa mas no risco que correm as pessoas por causa dos veículos ou máquinas (transporte, acidentes do trabalho). ${ }^{154}$

Para De Plácido e Silva, ao lado do sentido de perigo, perda ou temor de fato, que cause perda, o termo risco exprime a obrigação de ressarcir os danos que advenham da vinda do fato ou evento temido ou receado, asseverando, por isso, ser redundante a frase "assumir a responsabilidade dos riscos". ${ }^{155}$

O Direito Civil italiano, em razão do sistema adotado com o artigo 2.050 do seu Código Civil de 1942, por ser, outrossim, norma inspiradora da nossa legislação, fornece importantes subsídios para a classificação do caráter perigoso da atividade. Conforme lição de Bittar, baseada na doutrina daquele país, dissertando sobre o aludido artigo 2.050:

[...] têm os autores acentuado, a partir do texto citado, que a atividade deve ser considerada, ou não, perigosa, sob o prisma substancial, tendo-se em conta uma objetiva periculosidade, ínsita em si mesma ("periculosidade intrínseca") ou posta em relação aos meios empregados, com base em extensas referências, inclusive jurisprudenciais. ${ }^{156}$

Assim, para a doutrina e jurisprudência italianas, é perigosa a atividade que contenha em si um alto potencial danoso em relação ao critério da normalidade média, fixada por meio de estatísticas, de elementos técnicos e da própria experiência comum. ${ }^{157}$

A relatividade do conceito, porém, é objeto de críticas pertinentes, uma vez que, como ressaltou Bittar, uma mesma atividade pode, em determinadas condições, assumir ou perder a natureza de risco, dificultando a aplicação do regime legal especial. ${ }^{158}$ A despeito de tais críticas, a cláusula geral afigura-se importantíssimo instrumento de

\footnotetext{
${ }^{154}$ LOPEZ, Teresa Ancona. op. cit., p. 27-28.

${ }^{155}$ SILVA, De Plácido e. Vocabulário jurídico. 8. ed. Rio de Janeiro: Forense, 1984. p. 148-149.

${ }^{156}$ BITTAR, Carlos Alberto. op. cit., p. 99.

${ }^{157}$ Id., loc. cit.

${ }^{158}$ Id. Ibid., p. 100-101.
} 
justiça social, porquanto identificada a atividade de risco não legalmente capitulada, poderá, o Poder Judiciário, conceder o devido e imediato amparo jurídico, completando-se o quadro protecionista da responsabilidade civil com o permanente diálogo que o direito deve manter com a realidade.

Não se pode deixar de frisar, no entanto, que, no direito italiano, a cláusula geral de risco é afastada se o causador da lesão demonstrar ter adotado todas as medidas idôneas para evitar a produção do dano, representando, dessa forma, verdadeira regra de inversão do ônus da prova.

Essa é a conclusão a que chega Godoy sobre a fórmula italiana de derrogação da regra geral:

[...] malgrado se imponha a responsabilidade pelo risco decorrente do exercício de atividade perigosa, abre-se ao lesante a possibilidade de dela se eximir, desde que comprove ter adotado todas as medidas idôneas, segundo as circunstâncias, para evitar a produção do dano. Mas se assim se faz, em dispositivo, diga-se, muito questionado e, em verdade, ausente no projeto original do Código, por isso objeto de restrito debate prévio, a rigor parece manter-se a legislação, pese embora não faltar quem sustente tese diversa, no campo da responsabilidade subjetiva, posto que com inversão do ônus probatório em favor da vítima. Afinal, estabelecendo a justificativa citada, a discussão acaba girando em torno do conceito de má conduta, de conduta diligente, de cautela, de prevenção, conforme as medidas possíveis e esperadas do dano causado. ${ }^{159}$

O risco da atividade normalmente desenvolvida pelo autor do dano é, assim, aquela incerteza que acompanha o progresso material da humanidade. Não é um risco comum por todos assumido. É o risco especial em relação ao risco comum, conforme leciona Teresa Ancona Lopez:

É preciso que a Doutrina e a Jurisprudência dêem os limites e critérios para a responsabilidade pela atividade perigosa (nem ato, nem produto), pois tudo na vida apresenta risco e perigo e, se começarmos a interpretar todas as atividades como perigosas, acabaremos por colocar também os indivíduos respondendo pela teoria do risco, como, por exemplo, o dano

${ }^{159}$ GODOY, Cláudio Luiz Bueno de. op. cit., p. 60. 
provocado por um ciclista ou até de uma dona de casa empurrando o carrinho de supermercado ou de seu bebê e atropelando os transeuntes. ${ }^{160}$

\subsubsection{Teorias que fundamentam o risco}

São várias as teorias que fundamentam o risco, destacando-se, dentre elas, a do risco integral, a do risco-proveito, a do risco criado, a do risco profissional, a do risco excepcional e a do risco social.

\subsubsection{Teoria do risco integral}

Em um primeiro momento, comprometida no extremismo, aparece a teoria do risco integral, bastando, para caracterização do dever de indenizar, a verificação de um dano ligado a um fato. Esta teoria não contempla qualquer excludente da obrigação de indenizar, tendo sido admitida, no nosso direito, apenas em hipóteses especiais. ${ }^{161}$

Quanto à gravidade dessa modalidade de risco, Cavalieri Filho afirma que é “destinada a justificar o dever de indenizar até nos casos de inexistência do nexo causal". 162

\subsubsection{Teoria do risco-proveito}

A teoria do risco-proveito surge sob o fundamento de que quem lucra pondo em risco a vida, a integridade física e os bens de terceiro, deve arcar com os prejuízos ( $u b i$ emolumentum, ibi onus). ${ }^{163}$

\footnotetext{
${ }^{160}$ LOPEZ, Teresa Ancona. op. cit., p. 167.

${ }^{161}$ SILVA, Regina Beatriz Tavares da. In: FIÚZA, Ricardo (Coord.). Novo Código Civil comentado. São Paulo: Saraiva, 2002. p. 820.

${ }^{162}$ CAVALIERI FILHO, Sérgio. op. cit., p. 138-139.

${ }^{163}$ LOPEZ, Teresa Ancona. op. cit., p. 44.
} 
A conceituação do que configura proveito é a grande dificuldade dessa modalidade de risco. Cavalieri Filho, esclarecendo sobre a dificuldade de se dizer quando uma pessoa tira proveito de uma atividade, formula a seguinte provocação: seria esse proveito econômico ou bastaria qualquer tipo de proveito ${ }^{164}$

Admitir-se qualquer proveito, significaria, pelo alto grau de indeterminação do conceito, retornar ao período da vingança privada administrada pelo poder público. Optar pelo proveito econômico restringiria a aplicação da teoria aos comerciantes e industriais, com a agravante de a vítima ter o ônus de provar a obtenção do proveito, retornando o problema da prova. ${ }^{165}$

\subsubsection{Teoria do risco criado}

Mais ampla que a teoria do risco-proveito, sobrevém a teoria do risco-criado, segundo a qual o dever de reparar o dano decorre da atividade normalmente exercida pelo agente que cria risco a direitos ou interesses alheios, não se exigindo, para tanto, proveito ou vantagem para aquele que exerce a atividade. ${ }^{166}$

$\mathrm{O}$ risco da atividade, segundo Teresa Ancona Lopez, tem fundamento na distribuição dos riscos e é verificado quando expressamente tipificado em lei ou quando a atividade normalmente desenvolvida pelo autor do dano implicar, por sua natureza, risco para os direitos de outrem. ${ }^{167}$

Assim, ingressam na noção de perigosa, as atividades não capituladas em lei que, normalmente desenvolvidas pelo autor, guardem, em relação às demais, maior grau de risco, justificando, assim, a aplicação de uma responsabilidade especial.

Não há dúvidas quanto às vantagens da adoção dessa modalidade de apuração de risco, na medida em que fornece ao Poder Judiciário meios para, ao identificar

\footnotetext{
${ }^{164}$ CAVALIERI FILHO, Sérgio. op. cit., p. 137.

${ }^{165}$ Id. Ibid.

${ }^{166}$ SILVA, Regina Beatriz Tavares da. op. cit., p. 820.

${ }^{167}$ LOPEZ, Teresa Ancona. op. cit., p. 47.
} 
atividades concretas de risco, assim caracterizá-las, com enormes perspectivas de amparo a vítimas do fenômeno perigoso. ${ }^{168}$

\title{
3.2.1.4. Teoria do risco profissional
}

A teoria do risco profissional fundada nos acidentes do trabalho que são cobertos por seguro, foi, ao mesmo tempo da teoria anterior, desenvolvida para, independentemente de culpa e sob a perspectiva da solidarização dos riscos e dos danos, viabilizar a reparação dos acidentes ocorridos com os empregados no trabalho ou por ocasião dele. ${ }^{169}$

Segundo doutrina de nomeada ${ }^{170}$, a responsabilidade civil baseada na culpa, especialmente no que se refere aos acidentes do trabalho, quase sempre levava à improcedência da ação acidentária. Além disso, como constata Cavalieri Filho:

\begin{abstract}
A desigualdade econômica, a força de pressão do empregador, a dificuldade do empregado de produzir provas, sem falar nos casos em que o acidente decorria das próprias condições físicas do trabalhador, quer pela sua exaustão, quer pela monotonia da atividade, tudo isso acabava por dar lugar a um grande número de acidentes não indenizados, de sorte que a teoria do risco profissional veio para afastar esses inconvenientes. ${ }^{171}$
\end{abstract}

A idéia de um Direito Social, informado pelo princípio da solidariedade, só veio depois que a Corte de Cassação da França, em 16 de julho de 1896, afastou qualquer pressuposto de culpa para a reparação dos danos causados por acidentes do trabalho. A repercussão dessa decisão foi tal, que ensejou uma lei específica sobre acidentes do trabalho - lei francesa de 9 de abril de 1898, prevendo a responsabilização objetiva com

\footnotetext{
${ }^{168}$ BITTAR, Carlos Alberto. op. cit., p. 100-101.

${ }^{169}$ CAVALIERI FILHO, Sérgio. op. cit., p.138.

${ }^{170}$ SAAD, Teresinha Lorena Pohlmann. op. cit., p. 28. "A iniqüidade dessa teoria é bem ilustrada por Hernains Marquez, lembrando a estatística citada por Garcia Ormaechea: na Espanha, desde 1828 até a primeira lei de acidentes, em 1900, ou seja, durante os 72 anos em que se julgavam os acidentes do trabalho, segundo princípios civilistas da culpa, houve apenas uma sentença reconhecendo a culpa do patrão pela morte do trabalhador."

${ }^{171}$ CAVALIERI FILHO, Sérgio. op. cit., p. 137.
} 
base no risco profissional e a estimativa legal das indenizações, constituindo a gênese dos Wefare States.

Sobre a diferença entre o risco profissional e o risco criado, acatamos a conclusão de Jorge Luiz Souto Maior e Marcus Orione Gonçalves Correia:

O novo modelo jurídico difere-se, fundamentalmente, do antigo em um aspecto: o da solidariedade social, que deixa o campo da moral para se integrar à ordem jurídica. Passa-se a reconhecer que do vínculo social advém a responsabilidade de uns para com os outros, cabendo ao Estado a promoção de todos os valores que preservem a vida, na sua inteireza, independentemente da condição econômica ou da sorte de cada um. A solidariedade, no sentido da preocupação de uns com a situação social e econômica de outros, deixa o campo da moral e passa a se integrar à ordem jurídica. A solidariedade é integrada, assim, ao campo da responsabilidade e esta não é mais uma responsabilidade civil e sim social, juridicamente exigível, sem necessidade de integração, a uma dada relação jurídica, dos elementos liberais, tais como a culpa e os limites estritos de um contrato (analisado do ponto de vista formal). ${ }^{172}$

\subsubsection{Teoria do risco excepcional}

O risco excepcional é aquele que não se insere na atividade normal da vítima, mas, no caso de danos, enseja reparação. Segundo a doutrina, são casos de responsabilidade excepcional os danos relacionados com rede elétrica de alta tensão, exploração de energia nuclear, materiais radioativos etc ${ }^{173}$.

\subsubsection{Teoria do risco social}

A teoria do risco social, se ainda apenas uma utopia no Brasil, já é a realidade de alguns poucos países, como dão conta estudos de Teresa Ancona Lopez:

\footnotetext{
${ }^{172}$ SOUTO MAIOR, Jorge Luiz; CORREIA, Marcus Orione Gonçalves. O que é direito social? In: CORREIA, Marcus Orione Gonçalves (Org.). Curso de direito do trabalho: teoria geral do direito do trabalho. São Paulo: LTr, 2007. v. 1, p. 22-23.

${ }^{173} \mathrm{Na}$ doutrina, há divergência sobre o tipo de risco em que se enquadra o dano nuclear, previsto no artigo 21 , inciso XXIII, letra "d”, da Constituição Federal de 1988. Uma corrente defende a teoria do risco integral, enquanto outra, a teoria do risco excepcional.
} 
Tendo em vista a imprevisibilidade da extensão e a gravidade dos danos que podem existir nesta nova sociedade, podemos ter um seguro total e instituído cobrindo todo e qualquer dano, seja anônimo seja conhecido. Esse seguro seria estatal e os numerários para as indenizações viriam dos "Fundos de garantia" (públicos), já existentes em parte em vários países da Europa como Alemanha, França e Itália. Nesses casos tanto faz o autor do dano. O importante é ressarcir as vítimas pelo Seguro Social dos Fundos Públicos. É a indenização sem responsabilidade. ${ }^{174}$

\subsubsection{Teoria adotada no Brasil}

A teoria do risco criado, no Brasil, é vigorosamente defendida por Alvino Lima, ao refutar o argumento de que não tem lugar a responsabilidade objetiva, onde não há proveito. A esse respeito declara o autor que:

\footnotetext{
"se agirmos criando um risco ameaçador da integridade ou do patrimônio de terceiro, procuramos tirar dessa atividade proveito maior possível. Se não conseguirmos, nem por isso deixamos de criar o risco, tendo em vista uma finalidade de lucro, sem que a vítima tenha concorrido para a sua não realização". ${ }^{175}$
}

Caio Mário, nada obstante severas críticas à corrente objetivista, também adere à teoria do risco criado, asseverando que, insurgir-se contra a idéia tradicional da culpa, é criar uma dogmática desafinada de todos os sistemas jurídicos; ficar somente com a culpa é entravar o progresso. ${ }^{176}$

O próprio dispositivo legal em comento não vincula a responsabilidade objetiva a um proveito com a atividade perigosa, revelando que o Código Civil optou pela teoria do risco criado.

Com campos de aplicação distintos, é importante frisar que a teoria do risco trata da atividade lícita que causa dano e não exclui o sistema fundado na culpa e, como

\footnotetext{
${ }^{174}$ LOPEZ, Teresa Ancona. op. cit., p. 48-49.

${ }^{175}$ LIMA, Alvino. Op. cit., p. 198.

${ }^{176}$ PEREIRA, Caio Mário da Silva. Instituições de direito civil. 13. ed. Rio de Janeiro: Forense, 2009. v. 3, p. 491.
} 
bem salientou Teresa Ancona Lopez, não basta o risco criado para gerar obrigação pela indenização; é necessário que tenha ocorrido o evento danoso. ${ }^{177}$

Convém registrar, ainda a propósito do tema, que o risco criado não se confunde com a teoria do risco profissional, que é aquele risco específico próprio da atividade profissional e que enseja cobertura por seguro. Neste, conforme posição de Teresa Ancona Lopez, a socialização dos riscos depende de Seguro Social e do Seguro privado obrigatório (com ação direta da vítima), pois, se for facultativo, não haverá solução do problema das indenizações. ${ }^{178}$

\subsection{Evolução das teorias subjetiva e objetiva no direito brasileiro}

O Código Civil brasileiro de 1916, com índole eminentemente patrimonialista e individualista, própria do momento histórico em que foi concebido, filiou-se à teoria subjetiva como regra geral, mas, abrindo exceções ao princípio, admitiu a responsabilidade objetiva nas hipóteses expressamente previstas em lei. Segundo Godoy:

\footnotetext{
De toda sorte, importa é reconhecer que a disciplina do Código Civil de 1916 acerca da responsabilidade civil, fiel à tradição dos códigos do século XIX, foi fundamentalmente calcada na culpa enquanto nexo de imputação, de modo a exigir a identificação de um culpado pela reparação, pela recomposição de prejuízo causado, uma diminuição, um desfalque patrimonial provocado pela prática de um ilícito. No máximo se abriam hipóteses especiais para a culpa presumida, que a jurisprudência acabou levando para o campo objetivo, mas sem uma regra geral acerca da responsabilidade independente de culpa, fincada em critério outro, como o do risco. ${ }^{179}$
}

Isso não impediu, porém, que a jurisprudência, diante de casos concretos, expandisse as fronteiras da responsabilidade objetiva, como registra Ney Stany Morais Maranhão:

\footnotetext{
${ }^{177}$ LOPEZ, Teresa Ancona. op. cit., p. 167.

${ }^{178}$ Id. Ibid., p. 53.

${ }^{179}$ GODOY, Cláudio Luiz Bueno de. op. cit., p. 28-29.
} 
Não sem razão que, mesmo dogmaticamente abafada com mãos violentas, a responsabilidade civil objetiva ainda chegou a irromper em alguns parcos dispositivos do Código Civil de 1916, como os que tratavam de direitos de vizinhança (CC/16, artigos 584 e 586) e de coisas lançadas ou caídas de imóveis (effusis et dejectis) (CC/16, artigo $1.529) .{ }^{180}$

O parágrafo único do art. 927 do Código Civil de 2002, inspirado no direito italiano e no direito português, impôs uma profunda modificação do sistema baseado na culpa, instituindo, ao lado da cláusula geral de responsabilidade subjetiva prevista no artigo 186, a responsabilidade objetiva, não só para os casos especificados em lei, como para todas as atividades consideradas de risco. ${ }^{181}$

De acordo com as lições de Godoy, o direito brasileiro, sem a causa de exclusão prevista no direito italiano, assumiu, de forma clara, a cláusula geral de responsabilidade baseada no risco como e enquanto nexo de imputação, trilhando caminho próprio, com maior potencialidade de aplicação. ${ }^{182}$

Assim, com a edição do novel Código Civil, o direito brasileiro, conforme observa Ney Stany Morais Maranhão, possui duas cláusulas gerais de responsabilidade civil, o que o coloca entre os mais avançados do mundo ${ }^{183}$, não sem causar certa perplexidade pela ampla abertura semântica do parágrafo único do artigo 927, como exemplifica aguda manifestação de Tereza Ancona Lopez:

Com a promulgação do novo Código Civil em 2002, um dos pontos mais festejados do novo estatuto foi a instituição da cláusula geral de responsabilidade civil fundada na teoria do risco (parágrafo único do artigo 927) e que, ao lado da cláusula geral da responsabilidade civil fundada na culpa (art. 186 e caput do artigo 927), governaria, doravante, o direito de danos. Não temos notícia de que em outro país do mundo ocidental exista norma geral tão completamente aberta sobre o risco da atividade e entregue totalmente ao arbítrio do magistrado, o que sem dúvida vai gerar conseqüências jurídicas sérias e graves. O legislador abriu mão de todos os seus poderes, não estabelecendo sequer critérios,

\footnotetext{
${ }^{180}$ MARANHÃO, Ney Stany Morais. Responsabilidade civil objetiva pelo risco da atividade: uma perspectiva civil-constitucional. Rio de Janeiro: Forense; São Paulo: Método, 2010. p. 221.

${ }^{181}$ TOLOMEI, Carlos Young. A noção de ato ilícito e a teoria do risco na perspectiva do novo Código Civil (arts. 186 a 188). In: TEPEDINO, Gustavo (Coord.). A parte geral do novo Código Civil: estudos na perspectiva civil-constitucional. 3. ed. rev. Rio de Janeiro: Renovar, 2007. p. 372.

${ }^{182}$ GODOY, Cláudio Luiz Bueno de. op. cit., p. 61-62.

${ }^{183}$ MARANHÃO, Ney Stany Morais. op. cit., p. 237.
} 
referências ou excludentes para auxiliar o Poder Judiciário na dura tarefa de julgar. ${ }^{184}$

Com essa nova formatação do direito brasileiro, cumpre destacar que a teoria do risco convive com a teoria clássica, sendo certo que aquela teve seus domínios sensivelmente alargados pelo Código Civil de 2002. Examinaremos, a seguir, as principais críticas à teoria da responsabilidade civil sem culpa.

\subsection{Críticas à teoria do risco}

Partidários da escola clássica articularam e ainda articulam contra a doutrina do risco, afirmando ser ela retrógrada, materialista e contrária à liberdade. ${ }^{185}$

Alvino Lima, em sua famosa obra sobre o assunto, tratou de rebater as críticas assacadas contra a teoria da responsabilidade sem culpa, asseverando que, embora partindo do fato em si mesmo para fixar a responsabilidade, inspira-se ela nos mais elevados princípios da justiça e da eqüidade, escrevendo a propósito que:

Não há, pois, negação da liberdade humana, mas antes, a sua proclamação, a sua segurança, a sua estabilidade jurídica. Não é o antiindividualismo, porque, assentando-se em bases sociais, na proteção da coletividade, a teoria do risco assegura ao indivíduo a reparação dos danos oriundos das atividades criadas pelos próprios homens, cujas causas não se descobrem, não se conhecem, não se provam, ou são ocultadas, astuta e triunfalmente, pelos causadores dos acidentes. Não é a socialização do direito que nega o indivíduo, que o relega a segundo plano, que lhe recalca os direitos; mas é a socialização do direito que, ante o perigo real da insegurança material dos indivíduos, refletindo-se nos interesses coletivos, proclama, defende e quer a "segurança jurídica". ${ }^{186}$

\footnotetext{
${ }^{184}$ LOPEZ, Teresa Ancona. op. cit., p. 162.

${ }^{185}$ Id. Ibid., p. 195.

${ }^{186}$ Id. Ibid., p. 196.
} 
O retrocesso às primitivas concepções da responsabilidade é uma dura crítica que se faz ao sistema objetivo, a qual afirma que a teoria preconiza a responsabilidade decorrente do simples fato, resultante da vingança pura, destruindo, assim, toda a evolução da teoria da responsabilidade.

Esta objeção também é repelida por Alvino Lima, fundamentando sua posição nas justificativas de ordem moral e de eqüidade, para a adoção da teoria do risco, inexistentes para a vingança privada. ${ }^{187}$

Cavalieri Filho acompanha essa ponderação, para quem a atividade perigosa terá de ser desenvolvida com segurança, sob pena de ter de responder pelo dano que eventualmente causar, independentemente de culpa. Para ele, a idéia de indenizar parte da idéia de violação do direito de segurança da vítima, não se afigurando uma forma de reação extremada e sem regras:

Toda teoria, assim que engendrada, sofre a inevitável tendência de ser levada a extremos. Seus expositores, normalmente, costumam apresentála como panacéia para todos os males. Com o correr do tempo, entretanto, nos embates com a realidade, vai sendo reduzida aos seus verdadeiros limites, ficando expurgada de seus exageros. ${ }^{188}$

As críticas acima apresentadas constituem o fundamento para toda a problemática da aplicação da responsabilidade objetiva e, no próximo tópico, dada a falta de definição de risco por parte do legislador, examinar-se-á, à luz dos métodos de interpretação, como é definido o campo de incidência da responsabilidade objetiva.

\subsection{Atividade de risco e campo de aplicação da responsabilidade objetiva}

A entrada em vigor do novel Código Civil não representou apenas uma singela reorganização do direito anterior. Ainda que seja fruto de um Projeto concebido nos anos 70, vem ele, num processo conhecido como movimento de descodificação, carregado de

\footnotetext{
${ }^{187}$ LOPEZ, Teresa Ancona. op. cit., 198.

${ }^{188}$ CAVALIERI FILHO, Sérgio. op. cit., p. 139.
} 
princípios e técnicas absolutamente avançadas e, nas palavras de Gustavo Tepedino, “o momento é de construção interpretativa e é preciso retirar do elemento normativo todas as suas potencialidades, compatibilizando-o, a todo custo, à Constituição da República"189.

Existe uma visível mudança na forma de pensar o direito.

De fato, ao contrário do que ocorria antes da promulgação do novo estatuto civil brasileiro, quando as hipóteses de risco vinham comodamente tipificadas em lei, hoje, também postas na forma de cláusula geral, conferem ampla liberdade de preenchimento de seu conteúdo, reservando-se, à doutrina e à jurisprudência, importante papel integrativo. ${ }^{190}$

Esse fenômeno, identificado como uma das principais características da era pós-moderna, tem profundos reflexos no direito interno de cada país, uma vez constatada a incapacidade de utilização dos métodos ortodoxos de regulação social, conforme, nesse sentido, muito bem descreveu Luís Roberto Barroso ${ }^{191}$ :

No direito, a temática já não é a liberdade individual e seus limites, como no Estado liberal; ou a intervenção estatal e seus limites, como no welfare state. Liberdade e igualdade já não são os ícones da temporada. A própria lei caiu no desprestígio. No direito público, a nova onda é a governabilidade. Fala-se em desconstitucionalização, delegificação, desregulamentação. No direito privado, o código civil perde sua centralidade, superado por múltiplos microssistemas. Nas relações comerciais revive-se a lex mercatoria. A segurança jurídica - e seus conceitos essenciais, como o direito adquirido - sofre o sobressalto da velocidade, do imediatismo e das interpretações pragmáticas, embaladas pela ameaça do horror econômico. As fórmulas abstratas da lei e a discrição judicial já não trazem todas as respostas. O paradigma jurídico, que já passara, na modernidade, da lei para o juiz, transfere-se agora para o caso concreto, para a melhor solução, singular ao problema a ser resolvido. ${ }^{192}$

\footnotetext{
${ }^{189}$ TEPEDINO, Gustavo. Crise de fontes normativas e técnica legislativa na parte geral do Código Civil de 2002. In:___ (Coord.). op. cit., p. XV.

${ }^{190}$ GODOY, Cláudio Luiz Bueno de. op. cit., p. 66.

${ }^{191}$ Id. Ibid.

${ }^{192}$ BARROSO, Luís Roberto. Fundamentos teóricos e filosóficos do novo Direito Constitucional brasileiro (pós-modernidade, teoria crítica e pós-positivismo). In: ___ (Org.). A nova interpretação constitucional: ponderação, direitos fundamentais e relações privadas. 3. ed. rev. Rio de Janeiro: Renovar, 2008. p. 4.
} 
No constitucionalismo pós-moderno, dessa forma, a cláusula geral, em contraposição ao modelo do direito subjetivo tipificado (positivismo jurídico), é uma técnica legislativa baseada em princípios e regras que coloca o direito em posição de efetivamente poder atender às múltiplas e possíveis situações danosas que reclamem tutela jurídica, assumindo a ideologia vigente no momento da sua aplicação. ${ }^{193}$ Assim, tipificação legal dá lugar à tipificação judicial.

Afirmando a vantagem do modelo não-tipificado, Pontes de Miranda diz que:

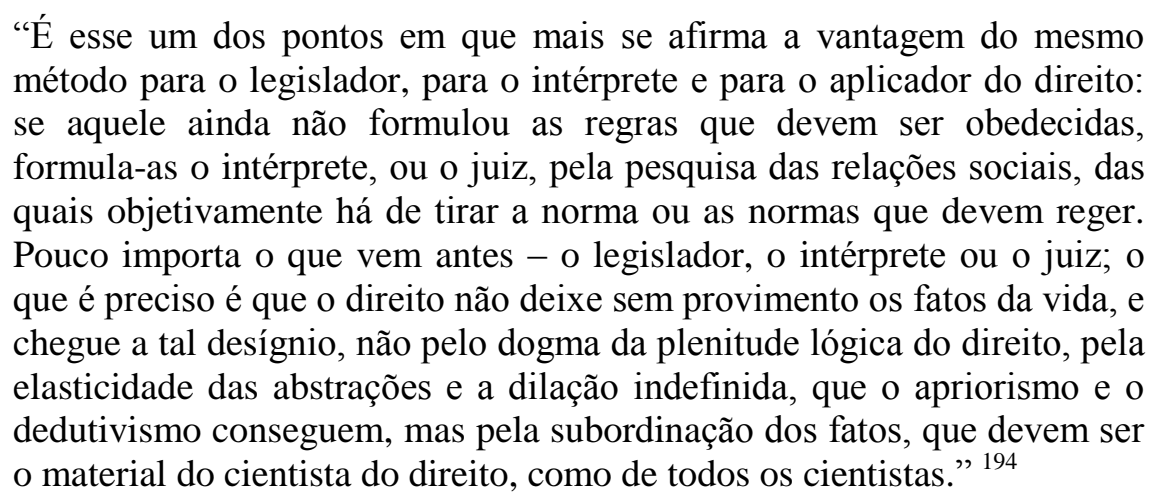

Assim, apresentada em forma de cláusula geral, é com espírito de extrair da norma toda a capacidade normativa que se apresenta a parte final do parágrafo único do artigo 927 do novo Código Civil, ou seja, a busca por sentido do seu conteúdo tem o objetivo de integrar juiz, intérprete e legislador.

Cláudio Luiz Bueno de Godoy diz que, por conta da exigência de adequação do direito posto à multiplicidade das relações, a cláusula geral "encerra um preceito normativo cujos termos são propositadamente abertos" tendo, pela fluidez e mobilidade do sentido das expressões empregadas e pelo alto grau de discricionariedade conferida ao intérprete, suscitado desconfiança e críticas quanto à segurança jurídica de tal método. ${ }^{195}$

O Código Civil de 2002, agravando essa sensação de insegurança quanto ao sentido da norma, não fixa qualquer ponto de referência valorativo para a determinação dos conceitos jurídicos indeterminados que apresenta.

\footnotetext{
${ }^{193}$ BARROSO, Luís Roberto. op. cit., p. 28.

${ }^{194}$ MIRANDA, Francisco Cavalcanti Pontes de. op. cit., p. 81.

${ }^{195}$ GODOY, Cláudio Luiz Bueno de. op. cit., p. 67.
} 
Contudo, o dispositivo não pode ser lido isoladamente. É colocado no contexto do constitucionalismo de vanguarda, informado pelas idéias de justiça e legitimidade, que promovem a reaproximação entre ética e direito. ${ }^{196}$ É uma nova forma de ver o direito, tornando imprescindível que o intérprete faça a conexão axiológica entre a regra e a Constituição Federal, que é o diploma que define os valores e princípios fundamentais da ordem pública. $^{197}$

Portanto, explícitos ou não, os princípios constitucionais sintetizam os valores contemplados no ordenamento jurídico, vinculando a interpretação e dando unidade e harmonia ao sistema, conforme lição de Luís Roberto Barroso:

De parte isto, servem de guia para o intérprete, cuja atuação deve pautarse pela identificação do princípio maior que rege o tema apreciado, descendo do mais genérico ao mais específico, até chegar à formulação da regra concreta que vai reger a espécie. Estes os papéis desempenhados pelos princípios: a) condensar valores; b) dar unidade ao sistema; c) condicionar a atividade do intérprete. ${ }^{198}$

Gustavo Tepedino, com muita propriedade, ao explicar como a ciência jurídica busca técnicas legislativas que possam assegurar uma maior efetividade ao direito, destaca que:

O legislador percebe a necessidade de definir modelos de conduta (standards) delineados à luz dos princípios que vinculam o intérprete, seja nas situações jurídicas típicas, seja nas situações não previstas pelo ordenamento. Daqui a necessidade de descrever nos textos normativos (e particularmente nos novos códigos) os cânones hermenêuticos e as prioridades axiológicas, os contornos da tutela da pessoa humana e os aspectos centrais da identidade cultural que se pretende proteger, ao lado de normas que permitem, do ponto de vista de sua estrutura e função, a necessária comunhão entre o preceito normativo e as circunstâncias do caso concreto. ${ }^{199}$

\footnotetext{
${ }^{196}$ BARROSO, Luís Roberto. op. cit., p. 28.

${ }^{197}$ TEPEDINO, Gustavo. op. cit., p. XX.

${ }^{198}$ BARROSO, Luís Roberto. op. cit., p. 29-30.

${ }^{199}$ TEPEDINO, Gustavo. op. cit., p. XXI.
} 
A despeito do quanto acima expendido quanto à falta de referências para a caracterização da atividade de risco que implique, por sua natureza, risco para os direitos de outrem, não há dúvida que, da leitura do dispositivo infere-se, pelo menos, uma regra clara: a caracterização da atividade de risco depende de uma manifestação judicial expressa. É um grande poder conferido ao Poder Judiciário e que deve, por isso, ser exercido com grande responsabilidade.

Desse modo, fora as hipóteses legais, o campo de incidência da responsabilidade objetiva dependerá da constatação, no caso concreto, de tratar-se de atividade de risco normalmente desenvolvida. Esta constatação é feita pelo próprio órgão julgador da causa, mediante decisão fundamentada, qualificando o risco especial que dispara a aplicação do regime excepcional de imputação.

Conclui-se, assim, que a parte final do parágrafo único do artigo 927 do Código Civil não tem aplicação automática. Depende de uma decisão judicial no bojo da própria causa e não derroga os princípios que informam o direito processual, ou seja, é uma decisão que também está submetida ao princípio da inércia, do devido processo legal, da ampla defesa, da fundamentação das decisões, do duplo grau etc.

O debate sobre a fixação do campo de aplicação da responsabilidade objetiva, contudo, é questão que se encontra sem uma orientação clara, dependendo, ainda, de uma atividade doutrinária e jurisprudencial no sentido de dar concretude ao instituto, como conseqüência própria da técnica das cláusulas gerais, adotada pelo Código Civil de 2002, sendo certo que a técnica legislativa, aliada ao princípio do livre convencimento motivado, previsto no art. 93, IX, da Constituição Federal de $1988^{200}$, acolhe qualquer ideologia, da mais conservadora à mais inovadora, desde que, do trabalho de interpretação, a conclusão seja no sentido da máxima eficácia do texto constitucional, mesmo quando se defronte com antagonismos inevitáveis.

\footnotetext{
${ }^{200}$ CINTRA, Antonio Carlos de Araújo; GRINOVER, Ada Pellegrini; DINAMARCO, Cândido Rangel. Teoria geral do processo. 20. ed. São Paulo: Malheiros Ed., 2004. p. 67-68. "A partir do século XVI, porém, começou a delinear-se o sistema intermediário do livre convencimento do juiz, ou da persuasão racional, que se consolidou sobretudo com a Revolução Francesa. Um decreto da assembléia constituinte de 1791 determinava aos jurados que julgassem suivant votre conscience et votre intime conviction; o código napoleônico de processo civil acolheu implicitamente o mesmo princípio. Mas é sobretudo com os estatutos processuais da Alemanha e Áustria que o juiz se libertou completamente das fórmulas numéricas. O Brasil também adota o princípio da persuasão racional: o juiz não é desvinculado da prova e dos elementos existentes nos autos (quod non est in actis non est in mundo), mas a sua apreciação não depende de critérios legais determinados a priori. O juiz só decide com base nos elementos existentes no processo, mas os avalia segundo critérios críticos e racionais."
} 
Sobre a colisão de princípios constitucionais, recorremos ao trabalho de Luís Roberto Barroso:

Princípios contêm, normalmente, uma maior carga valorativa, um fundamento ético, uma decisão política relevante, e indicam uma determinada direção a seguir. Ocorre que, em uma ordem pluralista, existem outros princípios que abrigam decisões, valores ou fundamentos diversos, por vezes contrapostos. A colisão de princípios, portanto, não só é possível, como faz parte da lógica do sistema, que é dialético. Por isso a sua incidência não pode ser posta em termos de tudo ou nada, de validade ou invalidade. Deve-se reconhecer aos princípios uma dimensão de peso ou importância. À vista dos elementos do caso concreto, o intérprete deverá fazer escolhas fundamentadas, quando se defronte com antagonismos inevitáveis, como os que existem entre a liberdade de expressão e o direito de privacidade, a livre iniciativa e a intervenção estatal, o direito de propriedade e a sua função social. A aplicação dos princípios se dá, predominantemente, mediante ponderação. ${ }^{201}$

Agora que o fundamento teórico e os argumentos estão apresentados, faz-se oportuno desenvolver, no próximo capítulo, o principal tema deste trabalho, a saber: a responsabilidade objetiva no acidente do trabalho.

${ }^{201}$ BARROSO, Luís Roberto. op. cit., p. 31. 


\section{RESPONSABILIDE CIVIL POR ACIDENTE DO TRABALHO}

\section{Noções introdutórias}

\subsection{Especificidades da relação de emprego}

Não se pode discorrer sobre a reparação dos acidentes do trabalho sem antes traçar, ainda que resumidamente, as características que diferenciam a relação de emprego das demais relações de direito privado e que ensejaram o seu tratamento diferenciado.

Esse é um exercício útil para orientar a interpretação dos princípios e regras aplicáveis ao Direito do Trabalho, como adverte Carlos Maximiliano:

Preceito preliminar e fundamental da Hermenêutica é o que manda definir, de modo preciso, o caráter especial da norma e a matéria de que é objeto, e indicar o ramo de Direito a que a mesma pertence, visto variarem o critério de interpretação e as regras aplicáveis em geral, conforme a espécie jurídica de que se trata. A teoria orientadora do exegeta não pode ser única e universal, a mesma para todas as leis, imutáveis no tempo; além dos princípios gerais, observáveis a respeito de quaisquer normas, há outros especiais, exigidos pela natureza das regras jurídicas, variável conforme a fonte de que derivam, o sistema político a que se acham ligadas e as categorias diversas de relações que disciplinam. O que não partir desse pressuposto, essencial à boa Hermenêutica, incidirá em erros graves e freqüentes. ${ }^{202}$

A sociedade moderna, especialmente após a revolução industrial, impôs e tem imposto severas mudanças nos padrões de comportamento humano, em seus mais variados âmbitos; entretanto, de uma forma geral (e cada vez mais), permanece ela “desconscientizada" dos elementos básicos da estrutura social, num fenômeno denominado “desacoplamento entre a modernidade e a racionalidade", como destaca Habermas:

\footnotetext{
${ }^{202}$ MAXIMILIANO, Carlos. Hermenêutica e aplicação do direito. 19. ed. Rio de Janeiro: Forense, 2010. p. 247.
} 
[...] as premissas do esclarecimento estão mortas, apenas suas conseqüências continuam em curso. Dessa perspectiva, uma ininterrupta modernização social auto-suficiente destaca-se dos impulsos de uma modernidade cultural que se tornou aparentemente obsoleta; ela opera apenas com as leis funcionais da economia e do Estado, da técnica e da ciência, as quais se fundem em um sistema. ${ }^{203}$

Esse fenômeno de alienação, próprio do funcionamento do capitalismo, alcançado graças à divisão social do trabalho e seus aprofundamentos, chegou a colocar a relação de trabalho, de forma proposital, para fora da estrutura social, tratando-a como uma relação de menor importância. Nas palavras de Bernard Eldelman, no "direito do trabalho" é todo o inconsciente do direito burguês que se dá no seu verdadeiro lugar; a tal ponto que esse "direito" pareceu por muito tempo "vil e vergonhoso", que ele pareceu como de uma raça jurídica inferior, um simulacro de direito, assim como o operário era um simulacro de homem. $^{204}$

Pode-se asseverar, assim, que a economia capitalista não é informada por princípios de ética e moral. ${ }^{205}$ Ao contrário do que se verificou em sociedades précapitalistas, nas quais o homem foi o objetivo central da produção (satisfação), o capitalismo tem por verdade fundante a eficiência, na medida em que a finalidade da produção capitalista não é a satisfação dos indivíduos, mas a riqueza pela riqueza. ${ }^{206}$ Os indivíduos, tanto o capitalista quanto o operário, funcionam apenas como suportes do capital, por serem suportes do dinheiro e da mercadoria e, como tal, como expressão do capitalismo (forças produtivas e relação de produção), encontram-se na base da sociedade capitalista $^{207}$. Conforme conclusão de Ângela Borges, isso quer dizer que, ainda que hodiernamente, em uma realidade pós-industrial, o capitalismo tenha criado novas formas de reprodução de suas condições de produção ${ }^{208}$, a relação de produção capital-trabalho ainda é a que sustenta toda a lógica capitalista e daí poder-se afirmar que o encontro dos

\footnotetext{
${ }^{203}$ HABERMAS, Jürgen. O discurso filosófico da modernidade. São Paulo: Martins Fontes, 2000. p. 6.

${ }^{204}$ ELDELMAN, Bernard. La légalisation de la classe ouvrière. Paris. Christian Bourgois Editeur, 1978. p. 15.

${ }^{205}$ HUBERMAN, Leo. História da riqueza do homem. 20. ed. Rio de Janeiro: Zahar Editores, 1985. p. 225.

${ }^{206}$ FAUSTO, Ruy. Marx: lógica e política. São Paulo: Brasiliense, 1983. p. 45.

${ }^{207}$ MARX, Karl. O capital: crítica da economia política. Tradução de Reginaldo Sant'Anna. 25. ed. Rio de Janeiro: Civilização Brasileira, 2008. Livro I, p. 182-183.

${ }^{208}$ BORGES, Ângela. Mercado de trabalho: mais de uma década de precarização. In: DRUCK, Graça; FRANCO, Tânia (Orgs.). A perda da razão social do trabalho: terceirização e precarização. São Paulo: Boitempo, 2007.
} 
indivíduos na relação de trabalho não se dá de forma meramente contingente, como sói acontecer com outras espécies de relação jurídica.

Assim, a relação laboral não se reduz a uma simples relação de venda de força de trabalho em troca de salário. Tem, como já mencionado, características especiais e, na relação de apreensão do trabalho excedente (mais-valia), o trabalhador, desprovido dos meios de produção, só tem, para vender, sua força de trabalho ${ }^{209}$, o que revela tipo contratual especialíssimo, que se aproxima do contrato coativo, conforme lição de Venosa:

Ambas as partes são forçadas a contratar. A interpretação das cláusulas e o inadimplemento, nesse caso, não podem ser vistos de forma igual aos demais contratos, nem mesmo aos contratos de adesão. Existe no fenômeno aparência de contrato e não contrato propriamente dito. Tratase de negócio jurídico guarnecido de normas de Direito Público. Resolvem-se as pendências levando-se em conta princípios de Direito Público, embora parcela ponderável das cláusulas situe-se no âmbito da contratação privada e como tal deva ser encarada. ${ }^{210}$

A propósito desse tema, Ruy Fausto, analisando a tese marxista, apontou:

A "redução a uma aparência" provocada pela continuidade do processo não atinge apenas a liberdade do contrato: ela concerne à própria idéia de que há uma troca de equivalentes. É através da continuidade propriamente que o capital interioriza os seus pressupostos e elimina a sua dependência em relação ao seu ponto de partida. Com efeito, no momento em que se considera o capital num fluxo contínuo, o valor que em forma de dinheiro é transferido para o operário enquanto salário aparece como valor extorquido sem equivalente no movimento anterior extorquido talvez de um outro operário, mas todas as diferenças individuais desaparecem na perspectiva da acumulação que só considera a relação entre classe e classe - e por isso a compra da força de trabalho deixa de ser uma verdadeira compra: o que o capitalista dá ao operário (à classe operária) em forma de salário é na realidade uma parte da riqueza criada pela própria classe operária. Riqueza que, ademais, é substituída por um novo produto - um novo subproduto - criado sempre pela classe

\footnotetext{
${ }^{209}$ FAUSTO, Ruy. op. cit., p. 50. "E assim se poderia afirmar - a conclusão que nos interessa - que, estabelecida a continuidade de voltas do capital que supõe a teoria da acumulação, a liberdade (dos contraentes, do operário em particular) se interverte em não-liberdade (a liberdade se torna uma aparência) e a propriedade, ou antes, o princípio de propriedade se interverte em princípio de não-propriedade. $\mathrm{O}$ trabalho, fonte de propriedade, se torna, por uma interverção interna, fonte de não-propriedade, de desapropriação contínua."

${ }^{210}$ VENOSA, Sílvio de Salvo. Direito civil: teoria geral das obrigações e teoria geral dos contratos. São Paulo: Atlas, 2001. p. 346.
} 
operária. Assim, não há mais equivalentes nem a rigor a troca, mas apropriação sem equivalente do trabalho alheio. ${ }^{211}$

Dessa forma, se o trabalhador não tem escolha senão "vender" sua força de trabalho e se o que agrega valor ao produto (o que produz riqueza numa sociedade) é o trabalho, parte do qual é retido pelo capitalista, verifica-se que a "troca" de força de trabalho por salário levada a efeito é aparente. Portanto, o contrato de trabalho não é sinalagmático nem comutativo ${ }^{212}$. Nada obstante, é a relação jurídica fundamental da sociedade capitalista.

Devido a essa especial configuração, justifica-se o porquê de a relação de emprego ter tratamento especial em relação às demais relações obrigacionais, com princípios e regras diretamente inviscerados na Constituição Federal de 1988, conforme constatam Jorge Luiz Souto Maior e Marcus Orione Gonçalves Marques:

No contexto da produção capitalista, que permite a utilização do trabalho humano de outrem para a geração de riquezas, aqueles que se beneficiam do sistema, ou melhor, que acumulam riquezas em função do trabalho alheio, na ótica do Direito Social, têm, naturalmente, uma responsabilidade redobrada, sendo que o primeiro modo concreto de cumpri-la é respeitando os direitos daqueles que, com seu trabalho, alimentam sua atividade econômica. Desse modo, a agressão aos direitos dos trabalhadores é um dos maiores atentados aos direitos sociais. O valor social do trabalho passa assim, a ser um dos pilares na edificação conceitual do Direito Social. ${ }^{213}$

Nessa nova dimensão constitucional, são fincados, no primeiro artigo, como fundamentos da República Federativa do Brasil, a dignidade da pessoa humana e os valores sociais do trabalho e da livre iniciativa.

O princípio da dignidade da pessoa humana é, assim, o valor norteador da sociedade brasileira e, por isso, tem sido objeto de vigorosa e incessante investigação científica acerca do seu significado e alcance, principalmente no campo do direito do trabalho.

\footnotetext{
${ }^{211}$ FAUSTO, Ruy. op. cit., p. 48.

${ }^{212}$ SOUTO MAIOR, Jorge Luiz. Curso de direito do trabalho: a relação de emprego. São Paulo: LTr, 2008. v. 2, p. 27-40.

${ }^{213}$ SOUTO MAIOR, Jorge Luiz; CORREIA, Marcus Orione Gonçalves. op. cit, p. 23.
} 
Luís Roberto Barroso afirma que:

O princípio da dignidade da pessoa humana identifica um espaço de integridade moral a ser assegurado a todas as pessoas por sua só existência no mundo. É um respeito à criação, independentemente da crença que se professe quanto à sua origem. A dignidade relaciona-se tanto com a liberdade e valores do espírito como com as condições materiais de subsistência. $\mathrm{O}$ desrespeito a esse princípio terá sido um dos estigmas do século que se encerrou e a luta por sua afirmação um símbolo do novo tempo. Ele representa a superação da intolerância, da discriminação, da exclusão social, da violência, da incapacidade de aceitar o outro, o diferente, na plenitude de sua liberdade de ser, pensar e criar. $^{214}$

Giselda Maria F. Novaes Hironaka, empreendendo profunda reflexão sobre a matéria, observa que a expressão "pessoa humana" constitui uma redundância sem um sentido preciso, que, no entanto, independentemente de qualquer crítica, por ser uma escolha política do legislador constituinte, deve ser ela decifrada e operacionalizada. Explica ela que:

É um problema terminológico que deve ser tratado antes mesmo de se esmiuçar, melhor, os detalhes da aplicação da expressão inteira. Porque pode ocorrer, simplesmente, de se estar fazendo um uso inadequado de uma expressão que não tem sentido pleno. Ou pode ser que, ainda que apresente um sentido coloquial, a expressão não apresente sentido suficiente para resistir às exigências do discurso racional e do discurso científico. A expressão dignidade da pessoa humana tem um uso constante na discussão jurídica e em especial na discussão dos direitos humanos e dos direitos fundamentais, mas nem sempre esse uso constante implica a formulação de um sentido preciso, efeito de uma definição sem lacunas ou entraves. ${ }^{215}$

Em busca de sentido e conteúdo para o princípio, Alexandre de Moraes, afirmando que a dignidade da pessoa humana, dá unidade aos direitos e garantias fundamentais, leciona:

\footnotetext{
${ }^{214}$ BARROSO, Luís Roberto. op. cit., p. 37-38.

${ }^{215}$ HIRONAKA, Giselda Maria Fernandes Novaes. op. cit., p. 162.
} 
A dignidade é um valor espiritual e moral inerente à pessoa, que se manifesta singularmente na autodeterminação consciente e responsável da própria vida e que traz consigo a pretensão ao respeito por parte das demais pessoas, constituindo um mínimo invulnerável que todo estatuto jurídico deve assegurar, de modo que, somente excepcionalmente, possam ser feitas limitações ao exercício dos direitos fundamentais, mas sempre sem menosprezar a necessária estima que merecem todas as pessoas enquanto seres humanos. O direito à vida privada, à intimidade, à honra, à imagem, dentre outros, aparecem como conseqüência imediata da dignidade da pessoa humana como fundamento da República Federativa do Brasil. Esse fundamento afasta a idéia de predomínio das concepções transpessoalistas de Estado e Nação, em detrimento da liberdade individual. ${ }^{216}$

Assim, justificando esse tratamento diferenciado, concluímos com Raimundo Simão de Melo, que o homem trabalhador deve ser visto como sujeito-fim e não como objeto-meio do desenvolvimento, "porque o fundamento para determinar o valor social do trabalho não pode ser o trabalho em si, mas o fato de que quem o realiza é um ser humano trabalhador, pelo que a dimensão da sua verificação será sempre subjetiva, pois o homem é o epicentro de tudo neste mundo". 217

\subsection{Conceito de acidente do trabalho}

A denominação "acidente do trabalho" nos é dada, hoje, pela Lei de Planos e Benefícios da Previdência Social (Lei n. 8.213, de 24 de julho de 1991), em seus artigos 19 e 20, segundo a qual "acidente do trabalho" é o que ocorre pelo exercício do trabalho a serviço da empresa ou pelo exercício do trabalho dos segurados referidos no inciso VII do

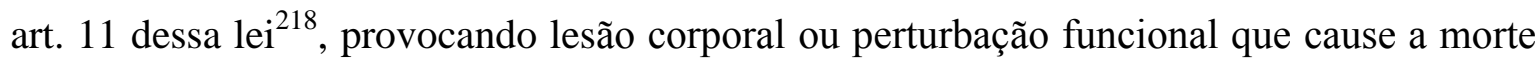
do segurado, ou a perda ou redução, permanente ou temporária, da sua capacidade para o trabalho.

\footnotetext{
${ }^{216}$ MORAES, Alexandre de. Direitos humanos fundamentais. 5. ed. São Paulo: Atlas, 2003. p. 61.

${ }^{217}$ MELO, Raimundo Simão de. Direito ambiental do trabalho e a saúde do trabalhador: responsabilidades legais, dano material, dano moral, dano estético, indenização pela perda de uma chance, prescrição. 4. ed. São Paulo: LTr, 2010. p. 66.

${ }^{218}$ Art. 11. São segurados obrigatórios da Previdência Social as seguintes pessoas físicas: I - como empregado...
} 
Esse conceito de acidente do trabalho também é estendido à doença profissional, assim entendida a produzida ou desencadeada pelo exercício do trabalho peculiar a determinada atividade e constante da respectiva relação elaborada pelo Ministério do Trabalho e da Previdência Social, ou a adquirida ou desencadeada em função de condições especiais em que o trabalho é realizado e com ele se relacione diretamente, também constante da relação elaborada pelo Ministério do Trabalho e da Previdência Social, acima citada.

A partir da dicção legal, infere-se que integram o conceito previdenciário de acidente o fato lesivo à saúde física ou mental que, ligado ao exercício do trabalho, resulte em morte ou em redução de capacidade laborativa.

Contudo, esse conceito, para o Direito Civil, é limitado, porquanto trata de acidentes do trabalho stricto sensu, relacionados com a morte ou com a perda ou redução da capacidade laboral do trabalhador segurado, visto que há, no âmbito da relação de laboral, outras conseqüências que não ensejam a aplicação da lei especial, mas que importam a responsabilidade do empregador, exigindo da doutrina e da jurisprudência, no que toca à responsabilidade civil, a construção de conceito mais amplo.

Lição de Pontes de Miranda dá conta de que o acidente do trabalho, prendendose ao fato "exercício do trabalho", costuma ser juridicamente definido como o fato súbito que causa dano ao corpo ou à saúde física ou psíquica do empregado. O renomado autor acima citado, em judiciosa crítica ao conceito formulado, afirma, no entanto, que a subitaneidade, como obra do acaso, não é elemento essencial de caracterização do infortúnio laboral. $^{219}$

Ratificando essa objeção, Raimundo Simão de Melo diz que:

Essa idéia clássica de acontecimento do acaso e de imprevisibilidade não mais se sustenta como regra geral dentro do atual conceito de acidente do trabalho, porque, como se sabe, grande parte dos acidentes laborais, na atual modernidade, decorre da ausência de cuidados mínimos e especiais no que diz respeito à adoção de medidas coletivas e individuais de prevenção dos riscos ambientais. Além disso, há inúmeras atividades caracteristicamente perigosas, cujos acidentes decorrentes não podem ser considerados meros infortúnios do acaso.

\footnotetext{
${ }^{219}$ MIRANDA, Francisco Cavalcanti Pontes de. Tratado de direito privado, cit., t. LIV, p. 84.
} 
É a partir dessa constatação que se faz a diferenciação entre acidente do trabalho típico e atípico. O acidente do trabalho típico decorre de um acontecimento súbito, violento e involuntário, que atinge a integridade física ou psíquica do empregado, no cumprimento de suas obrigações contratuais. O atípico decorre de doença profissional peculiar a certo ramo de atividade, por colocar o trabalhador em contato com substâncias que debilitam seu organismo. ${ }^{220}$

Essas são variações da concepção clássica do acidente do trabalho, que não cabem em um conceito simplista e linear, conforme observa Fernando José Cunha Belfort:

Pode-se afirmar que predomina, no Brasil e no mundo, a compreensão de que o acidente é um evento simples, com origens em uma ou poucas causas, encadeadas de modo linear e determinístico. Sua abordagem privilegia a idéia de que os acidentes decorrem de falhas dos operadores (ações ou omissões), de intervenções em que ocorre desrespeito à norma ou prescrição de segurança, enfim, "atos inseguros" originados em aspectos psicológicos dos trabalhadores. ${ }^{221}$

Diga-se, de passagem, que existem atividades perigosas que expõem os trabalhadores a danos previsíveis e inevitáveis e, ainda hoje, continuam causando severos danos aos trabalhadores, nada obstante toda a tecnologia e os equipamentos de proteção individual e coletiva existentes, como é o caso da doença laboral denominada silicose ${ }^{222}$.

Assim, o conceito de acidente do trabalho, sob a ótica da responsabilidade civil, é mais amplo, no sentido de abarcar qualquer conseqüência lesiva dele decorrente, ainda que não implique a morte, a perda ou a redução de capacidade laborativa do trabalhador (artigo $7^{\circ}$, inciso XXVIII, da Constituição Federal de 1988).

A despeito das limitações do conceito legal, Antônio Lago Júnior, nele baseado, formula a seguinte definição de acidente do trabalho:

\footnotetext{
${ }^{220}$ DINIZ, Maria Helena. op. cit., p. 507.

${ }^{221}$ BELFORT, Fernando José Cunha. op. cit., p. 138.

${ }^{222} \mathrm{~A}$ silicose é a mais antiga, mais grave e mais prevalente das doenças pulmonares relacionadas à inalação de poeiras minerais, confirmando a sua importância na lista das pneumoconioses. A descrição da doença já foi relatada há muitos séculos. É uma doença pulmonar crônica e incurável, com uma evolução progressiva e irreversível que pode determinar incapacidade para o trabalho, invalidez, aumento da suscetibilidade à tuberculose e, com freqüência, ter relação com a causa de óbito do paciente afetado. É uma fibrose pulmonar nodular causada pela inalação de poeiras contendo partículas finas de sílica livre cristalina que leva de meses a décadas para se manifestar. FUNDACENTRO. Disponível em: <www.fundacentro.gov.br/conteudo.asp?D=SES\&C=662>. Acesso em: 12 dez. 2010.
} 
Acidente do trabalho é aquele acontecimento mórbido, relacionado diretamente com o trabalho, capaz de determinar a morte do obreiro ou a perda total ou parcial, seja por um determinado período de tempo, seja definitiva, da capacidade de trabalho. Integram, pois, o conceito jurídico de acidente do trabalho: a) a perda ou redução da capacidade laborativa; b) o fato lesivo à saúde, seja física ou mental do trabalhador; c) o nexo etiológico entre o trabalho desenvolvido e o acidente, e entre este último e a perda ou redução da capacidade laborativa. ${ }^{223}$

\subsection{Evolução}

\subsubsection{Observações gerais}

A decadência do sistema liberal, período marcado pelos freqüentes excessos dos capitalistas, que estabelecia uma relação que atentava contra o próprio equilíbrio do regime econômico, em especial o concorrencial (excessos esses que, pela desigualdade econômica, anularam a possibilidade da realização da igualdade jurídica) ${ }^{224}$, levou ao avanço do modelo liberal, que passou a sofrer progressiva intervenção estatal ${ }^{225}$.

Segundo Jorge Luiz Souto Maior e Marcus Orione Gonçalves Correia, em minucioso exame sobre a formação do Estado Social:

Os diversos problemas sociais surgidos no período da Revolução Industrial, no entanto, vão exigir que os homens do direito busquem respostas diversas no ordenamento jurídico. $\mathrm{O}$ acidente do trabalho, fenômeno típico desta época, foi uma das razões fundamentais que

\footnotetext{
${ }^{223}$ LAGO JÚNIOR, Antonio. A responsabilidade civil decorrente do acidente de trabalho. In: LEÃO, Adroaldo; PAMPLONA FILHO, Rodolfo Mário Veiga (Coords.). Responsabilidade civil. Rio de Janeiro: Forense, 2001. p. 54-55.

${ }^{224}$ HUBERMAN, Leo. op. cit., p. 247. “A teoria do valor do trabalho, exposta pelos economistas clássicos no princípio da Revolução Industrial, servira a uma finalidade útil. A burguesia, então a classe progressista, transformara-a numa arma contra a classe politicamente retrógrada, mas poderosa dos donos de terra, que denunciava como desfrutando, sem trabalhar, a atividade de outras pessoas. Nas mãos de Ricardo, que usou juntamente com sua teoria da renda para atacar os donos de terra, a teoria do valor foi OK. Nas mãos de Marx, decididamente não foi OK. Marx aceitara a teoria do valor do trabalho e a levara mais além, ao que julgou ser a sua conclusão lógica. O resultado, aos olhos da burguesia foi desastroso. A situação se invertia totalmente. O que fora a sua arma na luta contra seu inimigo transformava-se na arma usada pelo proletariado contra ela!"

${ }^{225}$ MATOS, Olgória C.F. A Escola de Frankfurt: luzes e sombras do iluminismo. São Paulo: Moderna, 1993. p. 61 .
} 
impulsionou, mais tarde, a denominada luta de classes e a conseqüente reação no mundo jurídico. ${ }^{226}$

Foi, portanto, a discussão em torno da responsabilidade civil decorrente dos acidentes do trabalho que se desenvolveu a teoria da responsabilidade pelos riscos, sendo apontada, como marco histórico, a lei francesa de 9 de abril de 1898, sobre acidentes do trabalho, a qual, rompendo com o sistema clássico de imputação, adotou a teoria do risco profissional, conforme explica Pontes de Miranda:

Os sistemas jurídicos tiveram de atender a que a prestação de trabalho põe o empregado em situação, no espaço e no tempo, próxima do empregador, e sob a influência de circunstâncias que mais dependem do recebedor de serviços do que de qualquer outra pessoa. O próprio ambiente que se compõe com os elementos individuais dos empregados é mais ligado à organização empresarial do que ao grupo em colaboração. Daí a especialidade da lei de responsabilidade pelos fatos ilícitos absolutos, em que dois pontos foram e são cruciais: a abstração da culpa do empregador, mesmo no tocante à presunção da culpa; a determinação das indenizações, não conforme os danos apurados, mas conforme a estimativa legal. ${ }^{227}$

Ainda, segundo Pontes de Miranda:

A técnica legislativa, no tocante à liquidação das dívidas por acidentes do trabalho, tinha de escolher a simples indicação de dados que servissem aos arbitramentos, ou à estimativa legal. A segunda solução apresentou-se como a mais razoável, ou mesmo a única que se havia de acolher, para se evitarem o arbítrio judicial e a injustiça das avaliações. Para também se justificar a rigidez legal, argumenta-se que o empregador responde pelo risco e se tem de uniformizar a reparação para que se afastem discussões, retardamentos no adimplemento pelo empregador-devedor. ${ }^{228}$

Essa é a responsabilidade pelos riscos da atividade econômica (risco profissional) baseada no solidarismo a que se refere Teresa Ancona Lopez. Para esta prestigiada autora, o princípio solidarista aparece nas constituições européias do pós-guerra

\footnotetext{
${ }^{226}$ SOUTO MAIOR, Jorge Luiz; CORREIA, Marcus Orione Gonçalves. op. cit., p. 17.

${ }^{227}$ MIRANDA, Francisco Cavalcanti Pontes de. Tratado de direito privado. 3. ed. São Paulo: Ed. Revista dos Tribunais, 1984. t. LIV, p. 84.

${ }^{228}$ Id. Ibid.
} 
e, insculpido no inciso I, do seu artigo $3^{\circ}$, como um dos objetivos fundamentais da República, também integra a Constituição Federal brasileira de $1988 .{ }^{229}$

Assim, a socialização dos riscos, por fundar-se no seguro social ou no seguro privado obrigatório, com ressarcimento tarifado e certo, para todas as vítimas, estabeleceu um regime de responsabilidade objetiva baseado na solidarização dos riscos, como conclui Tereza Ancona Lopez:

Da mesma forma, na socialização dos riscos perde importância a fundamentação da responsabilidade na teoria da culpa ou do risco. $\mathrm{Na}$ verdade, estamos diante do "direito de danos", e não da responsabilidade em sentido estrito. ${ }^{230}$

Alguns autores, como é o caso de Teresinha Lorena Pohlman Saad, identificam que, da evolução da Seguridade Social, surgiu a teoria do risco social, projetando-se na doutrina estrangeira e nacional sobre o risco profissional, sob o fundamento da responsabilidade coletiva pelos riscos sociais. Esse enfoque coloca o pensamento jurídico no sentido da responsabilidade social. Contudo, frisa a própria autora que, passando o custeio do referido seguro para a exclusiva responsabilidade do empregador, o seguro de acidentes do trabalho não se libertou do risco específico do trabalho, ainda que amparado pela seguridade social. ${ }^{231}$

Ao lado da idéia da obrigação social pelo risco profissional decorrente dos riscos normais da atividade e que resultou na adoção do seguro social, também se desenvolveu a idéia de obrigação baseada na culpa do empregador.

A seguir, faz-se uma análise sobre como se deu, no nosso país, a evolução da responsabilidade civil por acidentes do trabalho.

\footnotetext{
${ }^{229}$ LOPEZ, Teresa Ancona. op. cit., p. 50.

${ }^{230}$ Id. Ibid., p. 53.

${ }^{231}$ SAAD, Teresinha Lorena Pohlmann. op. cit., p. 31-33.
} 


\subsubsection{Evolução no Brasil - breve histórico}

No Brasil colonial, o regime escravagista criou um ambiente pouco propício ao desenvolvimento de qualquer direito laboral e, menos ainda, ao da idéia de acidentes do trabalho ou de sua reparação.

Segadas Vianna, a propósito, destaca que:

No tempo do Império essas eram as condições de nosso País: as atividades agrícolas eram realizadas pelos escravos e estes nem ao menos se sentiam capazes de ser possuidores de qualquer direito; os casos registrados de rebelião, de fuga, de organização de confraria de pretos forros, tudo isso tinha como causa apenas o desejo de libertarem-se de alguns raros senhores violentos, mas nunca o anseio de uma igualdade jurídica, de obtenção de direitos e regalias, de que os escravos jamais tinham ouvido falar. Não existiam indústrias desenvolvidas e, salvo algumas, de instalações e métodos primitivos, de cerâmica e de madeira, tudo se fazia com um artesanato ainda incapaz de se organizar. ${ }^{232}$

O contexto desse modelo escravagista, aliado à lenta evolução do direito brasileiro nesse período, ainda marcadamente influenciado pelas Ordenações do reino, conforme já abordado no capítulo I desta dissertação, ${ }^{233}$ representou um profundo distanciamento dos avanços sociais que ocorriam no mundo europeu. Como atesta Segadas Vianna, mesmo com o início do desenvolvimento industrial, havia um evidente “desajustamento entre as condições normais de vida do trabalhador e aquelas que ele deveria ter direito" 234 , escrevendo, ainda, que:

Inexistia, entretanto, o espírito de classe e ainda não se haviam formado as concentrações de população operária; as reivindicações que se apresentavam, num e noutro ponto do País, eram atribuídas a agitações de anarquistas. Os acontecimentos dramáticos de Pernambuco, nos quais teve heróica atuação o Professor Joaquim Pimenta defendendo os trabalhadores, não chegaram a emocionar o proletariado do resto do

\footnotetext{
${ }^{232}$ SÜSSEKIND, Arnaldo; MARANHÃO, Délio; VIANNA, Segadas; TEIXEIRA FILHO, João de Lima. Instituições de direito do trabalho. 16. ed. São Paulo: LTr, 1996. v. 1, p. 52.

${ }^{233}$ Sobre a evolução da responsabilidade civil no Brasil, ver item 3 do Capítulo I.

${ }^{234}$ SÜSSEKIND, Arnaldo; MARANHÃO, Délio; VIANNA, Segadas; TEIXEIRA FILHO, João de Lima. op. cit., p. 54.
} 
Brasil. Nem as greves do Distrito Federal e de São Paulo tiveram o efeito de se transformar em "movimento ascendente", capaz de provocar o aparecimento de leis, não obstante todos esses acontecimentos se terem verificado depois da primeira grande guerra mundial. ${ }^{235}$

Até o final do século XIX, a sorte dos trabalhadores estava nas mãos dos respectivos patrões ou "senhores" proprietários de escravos. Ao contrário do que ocorreu em quase todo o mundo, no Brasil os direitos foram inicialmente fixados pelo poder público, com inspiração no direito estrangeiro, num processo evolutivo descendente caracterizado pela inexistência de luta para a criação do direito, falta de associações profissionais de expressiva representatividade, falta de organização dos grupos sociais e inexistência de atividades econômicas que exigiam massas proletárias densas. Ainda assim, mesmo na era colonial observa-se a criação de algumas leis com conteúdo trabalhista. ${ }^{236}$

É nesse contexto social que são editadas as primeiras leis, possibilitando a organização da classe trabalhadora e, a partir daí, viabilizando o processo legislativo ascendente pela luta e pela conquista de novos direitos.

As primeiras iniciativas de regulação dos acidentes do trabalho datam do início do século XX. Segundo Jayme Aparecido Tortorello, a história da legislação acidentária brasileira tem início com o Projeto n. 169, de 1904, tendo sido seguido de vários outros, todos não aprovados pelo Congresso Nacional. Apenas em 1919 surge a primeira lei brasileira sobre acidentes do trabalho. É a Lei n. 3.724, de 15 de janeiro de 1919, fundada na teoria do risco profissional. ${ }^{237}$

Nesse período, verifica-se um crescente interesse na matéria, com várias iniciativas para o seu aperfeiçoamento, até a edição do Decreto-Lei n. 7.036, de 10 de novembro de 1944, também com fundamento jurídico na teoria do risco profissional, o qual adotou, nos seus artigos 94 a 100, o princípio de que ao dano sofrido deve corresponder o pagamento de uma indenização a cargo do empregador e transferível à

\footnotetext{
${ }^{235}$ SÜSSEKIND, Arnaldo; MARANHÃO, Délio; VIANNA, Segadas; TEIXEIRA FILHO, João de Lima. op. cit., p. 54.

${ }^{236}$ Id. Ibid., p. 52.

${ }^{237}$ TORTORELLO, Jayme Aparecido. Acidentes do trabalho: teoria e prática. 2. ed. São Paulo: Saraiva: 1996. p. 4-5.
} 
entidade seguradora (privada ou previdenciária), mediante contrato de seguro obrigatório $^{238}$.

Curiosamente, esse decreto-lei, no seu artigo 31, dispunha que o pagamento nos moldes nele estabelecidos exonerava "o empregador de qualquer outra indenização de direito comum, relativa ao mesmo acidente, a menos que resultasse de dolo seu ou de seus prepostos".

Sobre essa questão, Jayme Aparecido Tortorello assim se manifesta:

Todavia, o Supremo Tribunal Federal, na interpretação desse artigo, culminou em equiparar o dolo de que falava a norma à culpa grave, com a edição da Súmula 229, cuja redação era a seguinte: “A indenização acidentária não exclui a do direito comum, em caso de dolo ou culpa grave do empregador", e os nossos pretórios, até a entrada em vigor da Constituição Federal de 1988, acabaram entendendo que essa regra se impunha como orientação básica para proteger as vítimas do infortúnio laborativo.

Ainda que o Supremo Tribunal Federal tenha assim se posicionado, a admissão da culpa grave como elemento caracterizador da responsabilidade civil pelos acidentes do trabalho ainda não abarcava todas as hipóteses de danos, como acontecia com os acidentes decorrentes de conduta lícita. Mesmo no caso de acidente-tipo a condição processual do acidentado era muito precária, porquanto teria de ser comprovado, pelo próprio prejudicado, o ato ilícito, a culpa grave e o liame etiológico.

A dificuldade de provar a culpa grave e estabelecer o nexo era tão grande, que foram raras as condenações judiciais por responsabilidade civil. ${ }^{239}$

Além disso, a culpa grave era facilmente elidida, uma vez demonstrado, pelo empregador, ter ele adotado todas as medidas legais e regulamentares para evitar o dano. Assim, no caso de uma doença como a silicose, ainda que comprovado o dano, bastava ao empregador demonstrar ter adotado as medidas de proteção preconizadas em lei e nos regulamentos do Ministério do Trabalho, para eximir-se da obrigação de indenizar, mesmo que tais medidas fossem notoriamente ineficazes para proteger o trabalhador das condições agressivas.

\footnotetext{
${ }^{238}$ TORTORELLO, Jayme Aparecido. op. cit., p. 6.

${ }^{239}$ SAAD, Teresinha Lorena Pohlmann. op. cit., p. 28.
} 
A Constituição Federal de 1988, prevendo um sistema de seguro para o acidente do trabalho e estabelecendo a responsabilidade do empregador pelos danos causados, no caso de dolo ou culpa, separou, definitivamente, o regime da infortunística do regime da responsabilidade civil. ${ }^{240}$

Dispõe o inciso XXVIII, do artigo $7^{\circ}$ da Constituição Federal de 1988 que:

Art. $7^{\circ}$ São direitos dos trabalhadores urbanos e rurais, além de outros que visem à melhoria de sua condição social:

XXVIII - seguro contra acidentes de trabalho, a cargo do empregador, sem excluir a indenização a que este está obrigado, quando incorrer em dolo ou culpa.

A questão, assim, passou para a esfera do Direito Civil, à época regida pelo artigo 159 do Código Civil, bastando a culpa leve para configurar o dever de indenizar. No campo da infortunística, ao contrário, manteve-se a responsabilidade objetiva, fundada na teoria do risco profissional, a qual informou todas as legislações brasileiras anteriores.

Por seus fundamentos diversos, a responsabilidade civil do empregador não se confunde com a prestação de benefício em dinheiro concedida pela Previdência Social ${ }^{241}$. Aquela tem natureza restitutiva, enquanto esta tem natureza alimentar. Portanto, são obrigações de diferentes naturezas que não se confundem e, conseqüentemente, não se compensam. ${ }^{242}$

Com a edição do Código Civil de 2002, imbuído da idéia da reparação do dano injusto, ainda que não culpado o ofensor, o regime da responsabilidade civil foi

\footnotetext{
${ }^{240}$ TORTORELLO, Jayme Aparecido. op. cit., p. 87-88.

${ }^{241}$ A Lei n. 8.213/91 estabelece que as prestações podem se dar em pagamento de benefício e prestação de serviços, conforme dicção do seu artigo 18: "O Regime Geral de Previdência Social compreende as seguintes prestações, devidas inclusive em razão de eventos decorrentes de acidente do trabalho, expressas em benefícios e serviços: I - quanto ao segurado:... h) auxílio-acidente; ... III - quanto ao segurado e dependente: a) (Revogada pela Lei $n^{0}$ 9.032, de 28.04.1995) b) serviço social; c) reabilitação profissional. § $1^{\mathrm{o}}$ Somente poderão beneficiar-se do auxílio-acidente os segurados incluídos nos incisos I, VI e VII do art. 11 desta Lei. (Redação dada ao parágrafo pela Lei $\mathrm{n}^{\circ}$ 9.032, de 28.04.1995); ...”

${ }^{242}$ TORTORELLO, Jayme Aparecido. op. cit., p. 88.
} 
sensivelmente alterado. De fato, nada obstante a manutenção da culpa como principal fundamento da obrigação de indenizar, o código também estabeleceu regra exceptiva do sistema geral, para os casos especificados em lei, ou quando a atividade normalmente desenvolvida pelo autor do dano implicar risco para os direitos de outrem.

Segundo Massimo Bianca, citado por Godoy:

[...] é o que se pode chamar de concepção eclética da responsabilidade civil, que reconhece o fundamento no que reputa serem os dois princípios básicos e gerais da matéria, o da culpa e do risco. Tese, ademais, que se coloca a meio-termo entre, de um lado, uma concepção dita eclética do tema, dedicado a sancionar conduta de culposa transgressão de um comando jurídico, e, de outro, concepção denominada tecnicista, em que a obrigação de indenizar se determina mercê de uma técnica de alocação do prejuízo, de reequilíbrio do dano, não propriamente de resposta a um ato culpável. ${ }^{243}$

A forma como se deu, no Brasil, a evolução da responsabilidade civil pelos acidentes do trabalho demonstra um crescente alargamento do dever de indenizar por parte dos empregadores, especialmente para, em atendimento ao sentimento imanente do homem por justiça, prover a manutenção do equilíbrio social.

Segue-se, pois, uma investigação das correntes que se formaram quanto ao nexo de atribuição da obrigação de indenizar os danos decorrentes do acidente do trabalho.

\section{Teorias sobre a obrigação de reparar os danos decorrentes de acidentes do trabalho}

Já foi visto, no presente trabalho, que a Constituição Federal de 1988, ao tratar da responsabilidade civil pelos acidentes do trabalho instituiu, em tese, a teoria da culpa como fundamento do dever de indenizar do empregador (art. $7^{\circ}, \mathrm{XXVIII).} \mathrm{Contudo,} \mathrm{com} \mathrm{a}$ edição do novel Código Civil de 2002, foi estabelecida, no parágrafo único do seu art. 927, cláusula geral da incidência da responsabilidade objetiva, quando a atividade normalmente desenvolvida pelo autor do dano implicar risco para os direitos de outrem.

\footnotetext{
${ }^{243}$ GODOY, Cláudio Luiz Bueno de. op. cit., p. 44.
} 
A questão que daí se levantou, como bem identificado por Belfort, era saber se a cláusula geral de risco seria aplicável aos casos de acidente do trabalho. ${ }^{244}$

Esse dispositivo ensejou e tem ensejado todo tipo de interpretação; das mais conservadoras, que defendem que nada foi alterado, na medida em que o dispositivo depende de regulamentação legal dispondo expressamente quais as hipóteses de incidência da responsabilidade objetiva (princípio da supremacia da Constituição) ${ }^{245}$, às mais vanguardistas, no sentido de que a obrigação de reparar o dano, nos casos de acidente do trabalho, aplicado o princípio constitucional do não retrocesso social (artigo $7^{\circ}$, caput, in fine, da $\mathrm{CR} / 88)^{246}$, não mais depende da comprovação de culpa ${ }^{247}$.

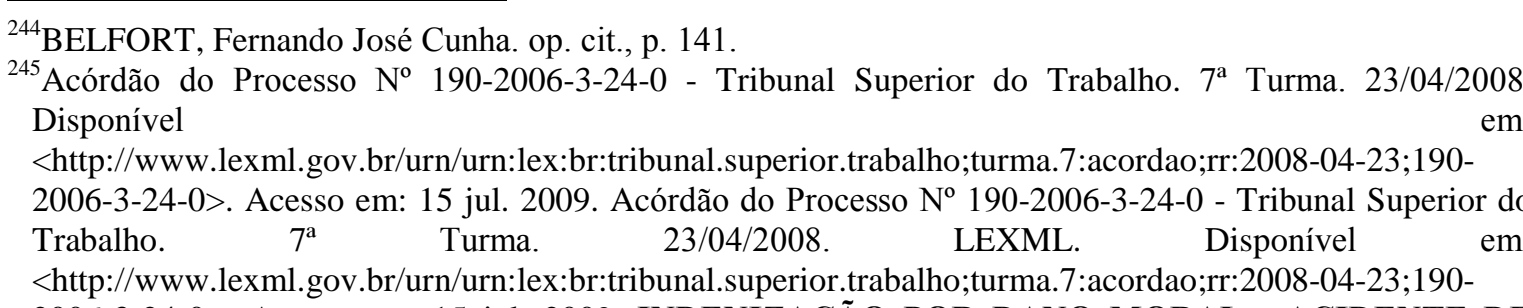
2006-3-24-0>. Acesso em: 15 jul. 2009. INDENIZAÇÃO POR DANO MORAL - ACIDENTE DE TRABALHO - RESPONSABILIDADE OBJETIVA - INAPLICABILIDADE - CF, ART. 7, XXVIII; CC, ART. 927, PARÁGRAFO ÚNICO.1. Para a existência do dever de reparar o dano causado, alguns pressupostos devem estar presentes, sem os quais o próprio instituto da responsabilidade não pode subsistir, quais sejam, o dano experimentado pelo ofendido, a ação ou a omissão do causador, o nexo de causalidade e a culpa ou o dolo. Trata-se do estabelecimento do nexo causal entre lesão e conduta omissiva ou comissiva do empregador, sabendo-se que o direito positivo brasileiro alberga tão-somente a teoria da responsabilidade subjetiva, derivada de culpa ou dolo do agente da lesão em matéria trabalhista $\left(\mathrm{CF}\right.$, art. $7^{\circ}$, XXVIII). 2. "In casu", o Regional concluiu que era indevida a pleiteada indenização por danos morais e materiais decorrentes de acidente de trabalho, pois a responsabilização da Empregadora dependeria de caracterização de sua culpa subjetiva, o que não ficou demonstrado nos autos, tampouco houve insurgência do Reclamante, no particular, o que, por conseguinte, exclui a possibilidade de se aferir o nexo de causalidade entre o acidente sofrido e a culpa do empregador. Conforme analisado pela Corte Regional, verificou-se apenas que o Obreiro sofreu acidente de trabalho, não sendo confirmada a culpa ou dolo da Reclamada, nem a ação ou omissão que teria ocasionado o mencionado acidente. 3. A pretensão obreira de reconhecimento da responsabilidade objetiva da Empregadora pelo dano sofrido vem calcada no parágrafo único do art. 927 do CC, que a reconhece na hipótese da atividade desenvolvida pelo autor do dano implicar, por sua natureza, risco para direito alheio. 4. Se, por um lado, a norma civil não alcança a esfera trabalhista, iluminada pelo comando constitucional do art. $7^{\circ}$, XXVIII, por outro, nenhuma atividade laboral está infensa a riscos de acidente (no próprio dizer de Guimarães Rosa, em sua epopéia "Grande Sertão: Veredas", "viver é muito perigoso"), mas a CLT somente admite o adicional de periculosidade para as atividades de risco acentuado, ínsito ao manuseio de explosivos, inflamáveis (art. 193), e energia elétrica (Lei 7.369/85, art. $1^{\circ}$ ), o que descartaria de plano a invocação da responsabilidade objetiva por risco em relação ao setor da construção civil, que é a hipótese dos autos. 5. Assim, não há como se atribuir responsabilidade à Empregadora pelos danos morais e materiais, decorrentes de acidente de trabalho sofridos pelo Reclamante, apenas considerando a teoria da responsabilidade objetiva.Recurso de revista não conhecido.

${ }^{246}$ Art. $7^{\circ}$ São direitos dos trabalhadores urbanos e rurais, além de outros que visem à melhoria de sua condição social:... (grifamos).

${ }^{247}$ Acórdão do Processo No 422-2004-11-5-0 - Tribunal Superior do Trabalho. 1 $1^{\text {a }}$ Turma. 17/12/2008. Disponível em: <http://www.lexml.gov.br/urn/urn:lex:br:tribunal.superior.trabalho;turma.1:acordao;rr:2008-12-17;4222004-11-5-0>. Acesso em: 15 jul. 2009. RECURSO DE REVISTA. DANO MORAL. RESPONSABILIDADE CIVIL DO EMPREGADOR. ACIDENTE DO TRABALHO. 1 . O novo 
Existe, por óbvio, corrente intermediária, que se baseia na verificação do caso concreto para a avaliação do risco e da incidência do regime da responsabilidade objetiva. É o que passaremos a investigar.

\subsection{Corrente subjetivista}

Para a corrente conservadora, também denominada subjetivista, a parte final do parágrafo único do artigo 927 do Código Civil brasileiro, diante do expresso comando constitucional estabelecendo a culpa como elemento caracterizador da obrigação de reparar os danos, não é aplicável às hipóteses de acidente do trabalho.

Aderindo a essa corrente, Ari Possidonio Beltran afirma que:

[...] nada mudou em relação à espécie de responsabilização, que, in casu, é iniludivelmente diferenciada daquela pela qual responde a instituição previdenciária, visto que, o empregador somente responderá, de forma concorrente, mediante prova de dolo ou culpa. Não há cogitar-se, pois, em responsabilidade objetiva, pois que tal responsabilidade é subjetiva. ${ }^{248}$

São argumentos consistentes que vêm fortalecidos por doutrina de nomeada, como exemplifica serena manifestação de Caio Mário da Silva Pereira:

Uma vez apurada a existência do fato danoso, caberá indenização por parte do ofensor ou de seu preponente; mas, como se não cuida da imputabilidade da conduta, somente há de ter cabida naqueles casos

Código Civil Brasileiro manteve, como regra, a teoria da responsabilidade civil subjetiva, calcada na culpa. Inovando, porém, em relação ao Código Civil de 1916, ampliou as hipóteses de responsabilidade civil objetiva, acrescendo aquela fundada no risco da atividade empresarial, consoante previsão inserta no parágrafo único do artigo 927. Tal acréscimo apenas veio a coroar o entendimento de que os danos sofridos pelo trabalhador, decorrentes de acidente do trabalho, conduzem à responsabilidade objetiva do empregador. 2. A atividade desenvolvida pelo reclamante - teste de pneus - por sua natureza, gera risco para o trabalhador, podendo a qualquer momento o obreiro vir a lesionar-se, o que autoriza a aplicação da teoria objetiva, assim como o fato de o dano sofrido pelo reclamante decorrer de acidente de trabalho. Inquestionável, em situações tais, a responsabilidade objetiva do empregador. 3. Recurso de revista conhecido e provido.

${ }^{248}$ BELTRAN, Ari Possidonio. Da responsabilidade subjetiva e objetiva do empregador por acidente do trabalho, ante as disposições do novo Código Civil. Revista do Departamento de Direito do Trabalho e da Seguridade Social, São Paulo, v. 1, n. 1, p. 223, jan./jun. 2006. 
expressamente previstos na lei, pois é claro, se for deixado sem uma frenação conveniente, a conseqüência será o inevitável desaparecimento da primeira, com os inconvenientes acima apontados, da equiparação da conduta jurídica à antijurídica. ${ }^{249}$

Para essa corrente, em nome da segurança jurídica, o conteúdo da cláusula geral, diante do tratamento constitucional da matéria e da opção legislativa pela responsabilidade subjetiva, só pode se dar por lei.

Concluímos, então, que essa corrente defende que o inciso XXVIII do artigo $7^{\circ}$ da Constituição Federal encerra uma regra que, portanto, tem de ser cumprida. Não admitem gradação. Conforme explica Luís Roberto Barroso:

Regras são proposições normativas aplicáveis sob a forma de tudo ou nada ("all or nothing"). Se os fatos nela previstos ocorrerem, a regra deve incidir, de modo direto e automático, produzindo seus efeitos. Por exemplo: a cláusula constitucional que estabelece aposentadoria compulsória por idade é uma regra. Quando o servidor completa setenta anos, deve passar à inatividade, sem que a aplicação do preceito comporte maior especulação. ${ }^{250}$

Não há, assim, para os subjetivistas, uma colisão de princípios. Há regra.

O comando é objetivo e só deixará, a regra, de incidir sobre a hipótese de fato que contempla, se for inválida, se houver outra mais específica ou se não estiver em vigor, operando-se, predominantemente, mediante a subsunção. ${ }^{251}$

Pablo Stolze Gagliano e Rodolfo Pamplona Filho, colocando-se entre os subjetivistas, afirmam que a Constituição Federal optou por um núcleo necessário ${ }^{252}$,

\footnotetext{
${ }^{249}$ PEREIRA, Caio Mário da Silva. Instituições de direito civil, cit. v. 3, p. 491.

${ }^{250}$ BARROSO, Luís Roberto. op. cit., p. 30-31. Os destaques pertencem ao original.

${ }^{251}$ Id. Ibid., p. 31.

${ }^{252}$ Segundo J.J. Gomes Canotilho, em sua obra Direito constitucional e teoria da constituição. 3. ed. Coimbra: Almedina, 1999. p. 431, "as teorias absolutas vêem no núcleo essencial um conteúdo normativo irrestringível, abstractamente fixado; as teorias relativas vêem no núcleo essencial o resultado de um processo de ponderação de bens. De acordo com a primeira orientação, o núcleo essencial é uma posição subjectiva de tal modo indisponível que não pode ser relativizada por qualquer direito ou interesse contraposto. Para a segunda, o núcleo essencial é o resultado de um processo de ponderação, constituindo aquela parte do direito fundamental que, em face de outros direitos ou bens constitucionalmente protegidos e com ele colidentes, acaba por ser julgada prevalecente e consequentemente subtraída à disposição do legislador."
} 
fundado na responsabilidade subjetiva, servindo como o seu próprio fundamento de validade. $^{253}$

Mais uma vez recorrendo a Barroso:

A distinção qualitativa entre regra e princípio é um dos pilares da moderna dogmática constitucional, indispensável para a superação do positivismo legalista, onde as normas se cingiam a regras jurídicas. A Constituição passa a ser encarada como um sistema aberto de princípios e regras, permeável a valores jurídicos suprapositivos, no qual as idéias de justiça e de realização dos direitos fundamentais desempenham um papel central. ${ }^{254}$

Porém, em que pese a inegável coerência científica dos subjetivistas, a exclusão, de forma peremptória, da possibilidade de ser, no caso concreto, avaliado o risco da atividade para fazer desencadear o regime especial de imputação, importa a renúncia de um importante instrumento jurídico à disposição do Poder Judiciário, principalmente se tomado o ritmo acelerado com que se tem dado as mudanças sociais.

Para Carlos Maximiliano, o Direito Moderno não pode ser interpretado isoladamente:

Propende o Direito moderno para atender mais ao conjunto do que às minúcias, interpretar as normas com complexo ao invés de as examinar isoladas, preferir o sistema à particularidade. Se isto se diz da regra escrita em relação ao todo, por mais forte razão se repetirá acerca da palavra em relação à regra. Ater-se aos vocábulos é processo casuístico, retrógrado. $^{255}$

A fragilidade da tese subjetivista está na exclusão, de forma peremptória, das hipóteses de acidentes do trabalho decorrentes de atividade lícita, conforme será tratado nos itens seguintes.

\footnotetext{
${ }^{253}$ BARROSO, Luís Roberto. op. cit., p. 245.

${ }^{254}$ Id. Ibid., p. 30.

${ }^{255}$ MAXIMILIANO, Carlos. op. cit., p. 220.
} 


\subsection{Corrente objetivista}

Em contraposição à corrente subjetivista, alguns estudiosos vislumbraram, na parte final do parágrafo único do artigo 927, a solução para todos os problemas da responsabilidade civil decorrente dos acidentes do trabalho.

Para essa corrente, a abstração da idéia de culpa decorre da interpretação sistemática do inciso XXVIII do artigo $7^{\circ}$ da Constituição Federal com o seu próprio caput. Como o Código Civil de 2002 estabelece direito que visa à melhoria da condição social dos trabalhadores urbanos e rurais, a responsabilidade objetiva passaria a integrar o rol dos direitos constitucionalmente a eles assegurados.

Analisando o fundamento subjacente a essa interpretação, os objetivistas consideram que a responsabilidade subjetiva prevista para os acidentes do trabalho é apenas um princípio e tratam a questão sob a ótica da colisão de princípios constitucionais, ou seja: a colisão entre o princípio constitucional da responsabilidade subjetiva da indenização por acidentes do trabalho (artigo $7^{\circ}$, XXVIII, da CR/88) e o princípio do nãoretrocesso social (artigo $7^{\circ}$, caput, in fine, da CR/88).

Assim, admitindo eles a aplicação do parágrafo único do artigo 927 do Código Civil, a operacionalização da cláusula geral de risco, segundo os objetivistas, decorre da própria lei como característica imanente da relação laboral, a teor do que dispõe o artigo $2^{\circ}$ da Consolidação das Leis do Trabalho:

Considera-se empregador a empresa, individual ou coletiva, que, assumindo os riscos da atividade econômica, admite, assalaria e dirige a prestação pessoal de serviços.

Como se vê, para essa corrente a própria lei dá o conteúdo da cláusula geral, uma vez que os riscos da atividade econômica são do empregador, na forma do art. $2^{\circ}$, caput, da Consolidação das Leis do Trabalho, numa tipificação legal da cláusula geral.

Por esse entendimento, a assunção dos riscos do empreendimento ou do trabalho, também denominada alteridade, carreia exclusivamente ao empregador os ônus 
decorrentes de sua atividade empresarial e do contrato empregatício celebrado, conforme lição de Maurício Godinho Delgado:

O texto da CLT parece limitar a alteridade apenas aos riscos tipicamente empresariais - e não aos riscos decorrentes da própria existência do contrato de trabalho e de seu cumprimento. É o que o art. $2^{\circ}$, caput, do diploma consolidado fala em riscos da atividade econômica, no mesmo preceito em que define empregador como empresa. Não obstante essa aparência, a interpretação lógico-sistemática e teleológica da ordem justrabalhista indica que se impõem, juridicamente, ao empregador também os riscos do trabalho prestado, ainda que este não tenha intuito econômico para o seu tomador (caso do trabalho doméstico). ${ }^{256}$

Nessa linha, Raimundo Simão de Melo, quanto ao grau de dificuldade de se identificar a atividade de risco no campo das relações laborais, diz:

No Direito do Trabalho, todavia, como se verá oportunamente, a tarefa do intérprete para identificar as atividades de risco será menos árdua, porque nesse ramo do Direito o assunto é de trato diário, começando com o conceito do art. $2^{\circ}$ da CLT, para se chegar especificamente às atividades de risco já reconhecidas na legislação, na doutrina e na jurisprudência, como é o caso das atividades insalubres, perigosas e penosas. ${ }^{257}$

É com base nessa orientação que o jurista acima citado defende a responsabilidade objetiva por todo e qualquer acidente de trabalho, escrevendo:

A solução definitiva para a questão é o reconhecimento da responsabilidade na modalidade objetiva por todo e qualquer tipo de indenização por acidente de trabalho, seja a cargo da Previdência Social, do empregador ou de eventual segurador privado, levando-se em conta o risco criado, como tendência inafastável do Direito contemporâneo. ${ }^{258}$

\footnotetext{
${ }^{256}$ DELAGADO, Maurício Godinho. op. cit., p. 393.

${ }^{257}$ MELO, Raimundo Simão. op. cit., p. 264.

${ }^{258}$ Id. Ibid., p. 325.
} 
Em outras palavras, igualando o fundamento da responsabilidade objetiva previdenciária (risco profissional) ao da responsabilidade civil decorrente da atividade de risco (risco criado), essa corrente doutrinária defende que o risco reclamado para desencadear a incidência da cláusula geral (artigo 927, parágrafo único, in fine, do Código Civil) seja automaticamente entendido como sendo o risco preconizado no artigo $2^{\circ}$ da Consolidação das Leis do Trabalho, estabelecendo uma conclusão apriorística de que qualquer acidente do trabalho decorre de uma atividade de risco.

É um raciocínio extremado que envolve vários problemas para a sua aplicação.

Se o abandono, pela corrente subjetivista, desse importante instrumento para verificação da responsabilidade de indenizar revela certo descompasso com a inovação trazida pela lei civil, a adoção da tese objetivista, transformando a responsabilidade objetiva em regra geral incidente a partir da simples constatação circunstancial de um dano verificado na relação de trabalho ${ }^{259}$, joga por terra toda a construção de uma hermenêutica baseada na ponderação e na razoabilidade.

A primeira dificuldade encontrada para a aplicação da tese objetivista está na confusão que essa tese estabelece entre os fundamentos da responsabilidade objetiva previdenciária e a responsabilidade objetiva fundada no risco da atividade. De fato, enquanto no primeiro caso temos o risco profissional, dependente de Seguro Social ou do seguro privado obrigatório, com indenização certa e tarifada, o segundo baseia-se no risco criado, como já tratado no item 3.2.2 do capítulo II, acima.

Dessarte, o risco profissional estabelece, numa tônica de socialização dos riscos, o direito de danos, e não da responsabilidade em sentido estrito ${ }^{260}$, não sendo demais, sobre esta questão, transcrever a conclusão de Teresa Ancona Lopez:

Portanto, afirmar, como alguns têm feito, que o parágrafo único do art. $927 \mathrm{CC} / 02$ veio socializar os riscos no Brasil é desconhecer como se dá esse mecanismo. "Socializar" para somente alguns pagarem a conta é não entender que em sociedade capitalista a visão econômica caminha junto com a social. ${ }^{261}$

\footnotetext{
${ }^{259}$ LOPEZ, Teresa Ancona. op. cit., p. 53.

${ }^{260}$ Id. Ibid.

${ }^{261}$ Id. Ibid.
} 
A segunda objeção que pode ser oposta a essa tese tem com o caminho hermenêutico para harmonização dos princípios aparentemente contrapostos. De fato, a tese defendida faz desaparecer, por completo, um comando constitucional expresso.

Conforme lição de Luís Roberto Barroso, no contexto do constitucionalismo moderno, os valores materializados em princípios devem ser compatibilizados, advertindo que, numa ordem pluralista, existem vários princípios que abrigam decisões, valores ou fundamentos diversos, que, por vezes, podem entrar em conflito. ${ }^{262}$

Citando Robert Alexy (Teoría de los derechos fundamentales. Madrid: Centro de Estudios Constitucionales, 1997), Barroso diz que os princípios se comportam diferentemente das regras. São "mandados de otimização" que admitem aplicação mais ou menos intensa de acordo com as possibilidades jurídicas existentes, sem que isso comprometa sua validade. É por isso que afirma que "a sua incidência não pode se dar em termos de tudo ou nada, de validade ou invalidade"263, ou seja, um não pode excluir o outro. Ratificando essa assertiva, Caio Mário adverte: “o juiz não tem a faculdade de revogar a lei"264.

Resumindo: as regras excluem-se enquanto os princípios coexistem. ${ }^{265}$

Canotilho, sobre a colisão de direitos fundamentais, explica que:

De um modo geral, considera-se existir colisão autêntica de direitos fundamentais quando o exercício de um direito fundamental por parte de seu titular colide com o exercício do direito fundamental por parte de outro titular. Aqui não estamos perante um cruzamento ou acumulação (como na concorrência de direitos), mas perante um "choque", um autêntico conflito de direitos. A colisão de direitos em sentido impróprio tem lugar quando o exercício de um direito fundamental colide com outros bens constitucionalmente protegidos. A colisão ou conflito de direitos fundamentais encerra, por vezes, realidades diversas nem sempre diferenciadas com clareza. ${ }^{266}$

\footnotetext{
${ }^{262}$ BARROSO, Luis Roberto. op. cit., p. 31.

${ }^{263}$ Id. Ibid. O destaque pertence ao original.

${ }^{264}$ PEREIRA, Caio Mário da Silva. Instituições de direito civil. 23. ed. Rio de Janeiro: Forense, 2010. v. 1.

${ }^{265}$ CANOTILHO, José Joaquim Gomes. op. cit., p. 1087.

${ }^{266}$ Id. Ibid., p. 1191.
} 
Assim, a compatibilização de princípios constitucionais em tensão se dá pela idéia de ponderação ou balanceamento. Segundo J.J. Gomes Canotilho, a idéia de ponderação ou de balanceamento surge sempre que haja necessidade de resolver casos de conflito entre bens juridicamente protegidos. ${ }^{267}$

Canotilho nos dá quando, enfim, se impõe a ponderação e o balanceamento:

Os pressupostos metódicos básicos são os seguintes. Em primeiro lugar, a existência, pelo menos, de dois bens ou direitos reentrantes no âmbito de protecção de duas normas jurídicas que, tendo em conta as circunstâncias do caso, não podem ser "realizadas" ou "optimizadas" em todas as suas potencialidades. Concomitantemente, pressupõe a inexistência de regras abstractas de prevalência, pois neste caso o conflito deve ser resolvido segundo o balanceamento abstracto feito pela norma constitucional. ${ }^{268}$

E continua:

Excluem-se, por conseguinte, relações de preferência prima facie, pois nenhum bem é, prima facie, quer excluído porque se afigura excessivamente débil, quer privilegiado porque, prima facie, se afigura com valor "reforçado" ou até absoluto. Isto implica a verificação e ordenação de cada caso ou grupos de casos específicos, de esquemas de prevalência parciais ou relativos, porque, nuns casos, a prevalência pode pender para um lado e noutros para outro segundo as ponderações ou balanceamentos efectuados ad hoc. Finalmente, é indispensável a justificação e motivação da regra de prevalência parcial assente na ponderação, devendo ter-se em conta sobretudo os princípios constitucionais da igualdade, da justiça, da segurança jurídica. ${ }^{269}$

Assim, a interpretação que invalida um princípio constitucional, para validar outro, é arbitrária. Nas palavras de Barroso:

A ponderação, como mecanismo de convivência de normas que tutelam valores ou bens jurídicos contrapostos, conquistou amplamente a doutrina e já repercute nas decisões dos tribunais. A vanguarda do pensamento

${ }^{267}$ CANOTILHO, José Joaquim Gomes. op. cit., p. 1161.

${ }^{268}$ Id. Ibid., p. 1164.

${ }^{269}$ Id. Ibid., p. 1164-1165. 
jurídico dedica-se, na quadra atual, à busca de parâmetros de alguma objetividade, para que a ponderação não se torne uma fórmula vazia, legitimadora de escolhas arbitrárias. É preciso demarcar o que pode ser ponderado e como deve sê-lo. A teoria dos princípios não importa o abandono das regras ou do direito legislado. Para que possa satisfazer adequadamente à demanda por segurança e por justiça, o ordenamento jurídico deverá ter suas normas distribuídas de forma equilibrada entre princípios e regras. ${ }^{270}$

Outra ponderosa crítica à tese objetivista, está na forma como propõe a complementação da cláusula geral de risco.

Ao partir da idéia de que a relação de emprego já encerra em si riscos que devem ser suportados pelo empregador, propõe essa corrente o preenchimento automático do conteúdo de uma cláusula geral por outra cláusula geral, corrompendo o sentido finalístico do parágrafo único do artigo 927 do Código Civil.

Para Godoy:

A propósito, desde logo se entende que, se expressamente referido na lei
um risco que a atividade normalmente desenvolvida induz, então não se
pode conceber um conteúdo para a cláusula geral em comento que seja de
causalidade pura, de nexo causal simples entre aquela mesma atividade e
a ocorrência de dano que seja dela decorrente, a despeito, inclusive, da
alteração de redação do parágrafo único do art. 963 do anteprojeto do
atual Código Civil, em sua versão original, tal como referido no item
4.3.2, mercê da qual enfim se suprimiu referência contida a um risco
especial da atividade normalmente desenvolvida.

No mesmo sentido, é oportuna a explicação dada por Ney Stany Morais Maranhão:

O que queremos anotar com toda a explanação é que o fator de imputação da obrigação de indenizar não é a atividade de risco, mas o risco da atividade. Perceba-se, a propósito, que a lei não fala em atividade arriscada, mas em atividade que implique risco. Agora, fato é que esse risco em grande parte só poderá ser aferido caso a caso, não havendo mesmo como se fixar, aprioristicamente, todas as atividades que induzam um grau acentuado de exposição a risco, a ponto de serem inseridos no comando normativo do artigo 927, parágrafo único, do Código Reale,

\footnotetext{
${ }^{270}$ BARROSO, Luis Roberto. op. cit., p. 33.

${ }^{271}$ GODOY, Cláudio Luiz Bueno de. op. cit., p. 95.
} 
sendo essa uma tarefa que terá de ser exercitada, pois, com percuciência, à luz das circunstâncias de cada caso concreto. ${ }^{272}$

Concluímos, assim, que, a despeito do inegável espírito humanitário da teoria objetivista $^{273}$, as críticas a essa corrente são inteiramente procedentes, retirando dela aptidão científica para fundamentar a aplicação da responsabilidade objetiva à reparação por danos decorrentes dos acidentes do trabalho.

\subsection{Corrente harmonizadora}

Nada obstante as duas correntes já citadas, há, ainda, outra possibilidade pouco explorada pelo direito brasileiro. Para efeitos didáticos, denominá-la-emos de harmonizadora.

Rizzardo sustenta que, no Brasil, no âmbito dos acidentes do trabalho, é patente a evolução da idéia de reparação. Em primeiro lugar aparece o dolo (Decreto-lei $n$. 7.036, de 1944); o dolo é, em seguida, equiparado à culpa grave, conforme entendimento sufragado na súmula n. 229 do Supremo Tribunal Federal; com a Constituição Federal de 1988, a responsabilidade previdenciária é separada da civil, bastando a mera culpa para estabelecer o nexo de imputação (artigo $7^{\circ}$, inciso XXVIII); e, por derradeiro, surge a responsabilidade objetiva baseada no risco criado (artigo 927, parágrafo único, in fine, do Código Civil). ${ }^{274}$

Para ele, essa progressão evolutiva significa que a Constituição Federal acolheu, no campo dos acidentes do trabalho e em hipóteses de risco especial, a responsabilidade objetiva pelo risco da atividade, na forma da inovação civil, nada obstante reconheça que a responsabilidade subjetiva permanece dominante, escrevendo, com base em Carlos Roberto Gonçalves, que:

\footnotetext{
${ }^{272}$ MARANHÃO, Ney Stany Morais. op. cit., p. 250-251.

${ }^{273}$ MAXIMILIANO, Carlos. op. cit., p. 138. "É claro que se não tolera a jurisprudência sentimental, a Gefühlsjuris-prudenz, audaciosa a ponto de torturar os textos para atender a pendores individuais de bondade e concepções particulares de justiça. Não se despreza o sentido evidente, nem se restringe um alcance dilatado, para proteger ou libertar uma pessoa. Raro é, entretanto, o caso em que a linguagem se não presta a mais de uma exegese; em tal emergência adote-se a interpretação mais humana e acorde com os interesses econômicos e morais da coletividade."

${ }^{274}$ RIZZARDO, Arnaldo. op. cit., p. 500.
} 


\begin{abstract}
Mister observar, todavia, que em situações especialíssimas as atividades propiciam a incidência da teoria do risco. Constituem-se aquelas que encerram não o perigo comum e inerente à própria vida, ou a qualquer tipo de atividade, mas as que, pelo texto de Carlos Roberto Gonçalves, merecem a concepção de perigosas "seja pela sua natureza (fabricação de explosivos, de produtos químicos, produção de energia nuclear etc), seja pelos meios empregados (substâncias, máquinas, aparelhos e instrumentos perigosos, transportes etc), e que comportam, então, "um tratamento especial em que não se cogita da subjetividade do agente para a sua responsabilização pelos danos ocorridos". ${ }^{275}$
\end{abstract}

No mesmo sentido é o enunciado n. 377 da IV Jornada de Direito Civil do Conselho da Justiça Federal, segundo o qual, “o art. $7^{\circ}$, inc. XXVIII, da Constituição Federal não é impedimento para a aplicação do disposto no art. 927, parágrafo único, do Código Civil quando se tratar de atividade de risco". ${ }^{276}$

Essa corrente, conquanto atribua ao inciso XXVIII do artigo $7^{\circ}$ da Constituição Federal a natureza de princípio, resolve o conflito de princípios, à igualdade da corrente objetivista, com base na ponderação. Entretanto, seus adeptos não expõem os fundamentos que os levaram a concluir pela compatibilidade do parágrafo único do artigo 927 do Código Civil de 20002 com o inciso XXVIII do artigo $7^{\circ}$ da Constituição Federal em vigor.

Assim, para a análise da validade da interpretação proposta por essa corrente, faz-se mister estabelecer se o direito previsto no inciso XXVIII do artigo $7^{\circ}$ da Constituição Federal de 1988, X encerra um princípio ou uma regra.

Segundo J.J. Gomes Canotilho, norma é o gênero, da qual são espécies as regras e os princípios. ${ }^{277}$

A diferenciação entre uma e outra espécie de norma é feita com base em vários critérios sugeridos pela doutrina. Canotilho aponta que a distinção pode ser feita pelo grau de abstração, grau de determinabilidade, caráter de fundamentalidade, proximidade da idéia de direito e natureza normogenética. Assim, os princípios revelam alto grau de abstração, necessitam das mediações concretizadoras, são normas com papel fundamental

\footnotetext{
${ }^{275}$ RIZZARDO, Arnaldo. op. cit., p. 502.

${ }^{276}$ FLÁVIO TARTUCE. Disponível em: <www.flaviotartuce.adv.br>. Acesso em: 05 jan. 2011.

${ }^{277}$ CANOTILHO, José Joaquim Gomes. op. cit., p. 1086.
} 
no ordenamento jurídico devido à sua posição hierárquica no sistema das fontes, são standards juridicamente vinculados nas exigências de justiça ou na idéia de direito ou são, ainda, fundamento de regras. As regras possuem um grau de abstração relativamente reduzido, são diretamente aplicados ao caso concreto por subsunção, podem ser vinculativas com um conteúdo meramente funcional. ${ }^{278}$

Como se vê, a questão não é simples.

Prima facie, à luz da forma de diferenciação acima mencionada, o comando constitucional em tela parece estabelecer uma regra, ou seja, que a indenização de direito comum é aferida mediante a responsabilidade subjetiva. Porém, a verdadeira norma subjacente, como afirma Godoy, é a que estabeleceu a dissociação da indenização do direito previdenciário da do direito comum, especificando ela que, nestes casos, não incide a responsabilidade objetiva decorrente do risco profissional. ${ }^{279}$

Portanto, para Godoy, o tipo de responsabilidade a incidir sobre a responsabilidade civil do empregador, nos casos de acidentes do trabalho, constitui um princípio.

De fato, se tomarmos os termos do caput do artigo $7^{\circ}$ da Constituição Federal de 1988, para fazer a interpretação do seu inciso XXVIII, teremos dois sentidos possíveis: a) de um lado, o que arrola como direito dos trabalhadores urbanos e rurais a limitação da responsabilidade civil aos acidentes do trabalho decorrentes de atos ilícitos culposos que causam danos e, b) de outro, o que confere o direito a indenização por danos decorrentes dos acidentes do trabalho com base no direito subjetivo, mencionando a espécie de responsabilidade, apenas para impedir, na esfera civil, a incidência da responsabilidade objetiva decorrente do risco profissional.

No primeiro caso, a hipótese é de regra, porque estabelece uma limitação expressa e clara, conforme defende a corrente subjetivista.

Contudo, a leitura do inciso em conjunto com o seu caput revela uma incongruência invencível, ou seja: como um direito pode ser concedido em termos de limitação?

${ }^{278}$ CANOTILHO, José Joaquim Gomes. op. cit., p. 1086.
${ }^{279}$ GODOY, Cláudio Luiz Bueno de. op. cit., p. 149-150. 
Por essa interpretação, toda a evolução da responsabilidade civil vista até agora é singelamente abandonada, porque exclui expressamente do rol dos direitos sociais dos trabalhadores urbanos e rurais o direito à indenização pelos acidentes do trabalho decorrentes de atividade lícita, ou seja, hipóteses em que não há dolo ou culpa.

Verifica-se, assim, dois direitos em confronto. De fato, existe, de um lado, um núcleo essencial de justiça que não pode, em caso algum, ser violado (artigo $3^{\circ}$, inciso I, da Constituição Federal). De outro lado, uma regra que expressamente exclui, do direito à indenização, os acidentes do trabalho decorrentes de ato lícito, e que conduz o direito brasileiro a um momento anterior à própria legislação francesa sobre acidentes do trabalho, de 9 de abril de 1898, indo na contramão de toda a evolução da responsabilidade civil.

Não é demais lembrar que a vítima, nestes casos, já está arcando objetivamente com todas as conseqüências do evento danoso, ensejando ponderoso desequilíbrio social, que não pode ser ignorado pelo Direito, sob pena de autorizar danos sem nenhum tipo de compromisso social por parte do empregador.

Essa posição, a toda evidência, estabelece uma tensão diretamente com o princípio fundamental de justiça, insculpido no inciso I, do artigo $3^{\circ}$, da Constituição Federal de 1988, como objetivo fundamental da República Federativa do Brasil, obtendo um resultado desastroso e incompatível com os princípios fundantes da República brasileira.

A propósito, Carlos Maximiliano assevera que:

Preocupa-se a Hermenêutica, sobretudo depois que entraram em função de exegese os dados da Sociologia, como o resultado provável de cada interpretação. Toma-o em alto apreço; orienta-se por ele; varia tendo-o em mira, quando o texto admite mais de um modo de o entender e o aplicar. Quanto possível, evita uma conseqüência incompatível com o bem geral; adapta o dispositivo às idéias vitoriosas entre o povo em cujo seio vigem as expressões sujeitas a exame. ${ }^{280}$

${ }^{280}$ MAXIMILIANO, Carlos. op. cit., p. 135. 
É da compreensão de ser a Constituição instrumento de garantia da ordem, de progresso e de liberdade que se impõe uma interpretação sistemática e teleológica, assegurando-se preponderância a esta última.

Com esse espírito, emerge toda a força da corrente aqui denominada harmonizadora. Para essa corrente, a responsabilidade subjetiva preconizada no inciso XXVIII do artigo $7^{\circ}$ da Constituição Federal de 1988 constitui um princípio que, mediante a ponderação com o princípio fundamental de justiça, deve ser interpretado como a regra geral a ser aplicada aos casos de responsabilidade civil decorrentes do acidente do trabalho, não excluindo a incidência da regra exceptiva inserta na parte final do parágrafo único do artigo 927 do Código Civil de 2002, quando a atividade normalmente desenvolvida pelo autor do dano implicar, por sua natureza, risco para os direitos de outrem.

Essa interpretação revela total compatibilidade sistemática com a Constituição Federal. Sem conduzir-se a alternativas radicais, a corrente harmonizadora toma os valores constitucionalmente assegurados e adota uma interpretação sem relativizar qualquer deles.

Corroborando a tese defendida pela corrente harmonizadora, Alexandre de Moraes expõe que:

Os direitos fundamentais, dentre eles os direitos e garantias individuais e coletivos consagrados no art. $5^{\circ}$ da Constituição Federal, não podem ser utilizados como um verdadeiro escudo protetivo da prática de atividades ilícitas, tampouco como argumento para afastamento ou diminuição da responsabilidade civil ou penal por atos criminosos sob pena de total consagração ao desrespeito a um verdadeiro Estado de Direito. Os direitos e garantias fundamentais consagrados pela Constituição Federal, portanto, não são ilimitados, uma vez que encontram seus limites nos demais direitos igualmente consagrados pela Carta Magna (Princípio da relatividade ou convivência das liberdades públicas). Desta forma, quando houver conflito entre dois ou mais direitos ou garantias fundamentais, o intérprete deve utilizar-se do princípio da concordância prática ou da harmonização, de forma a coordenar e combinar os bens jurídicos em conflito, evitando o sacrifício total de uns em relação aos outros, realizando uma redução proporcional do âmbito de alcance de cada qual (contradição dos princípios), sempre em busca do verdadeiro significado da norma e da harmonia do texto constitucional com sua finalidade precípua. ${ }^{281}$

\footnotetext{
${ }^{281}$ MORAES, Alexandre de. Direito constitucional. 26. ed. São Paulo: Atlas, 2010. p. 32-33.
} 
Concluímos, assim, que a corrente harmonizadora, ao admitir, no âmbito dos acidentes do trabalho, a responsabilidade objetiva como exceção ao sistema da culpa, tem, em termos científicos, os argumentos mais fortes dentre os das três aqui apresentadas.

Com essas considerações, dá-se por encerrada a terceira parte deste trabalho. 


\section{CONCLUSÃO}

O presente trabalho foi desenvolvido com a preocupação de serem retomados os fundamentos da obrigação pela reparação dos danos, desde seus instantes iniciais, estabelecendo-se, assim, uma linha de investigação com base nas orientações que em cada época materializaram a idéia de responsabilidade civil, para, ao final, identificar como, no Brasil, no que toca à indenização por danos decorrentes de acidente do trabalho, tem sido interpretada a cláusula geral de risco prevista na parte final do parágrafo único do artigo 927 do Código Civil, de 11 de janeiro de 2002, a qual estabelece a responsabilidade objetiva "quando a atividade normalmente desenvolvida pelo autor do dano implicar, por sua natureza, risco para os direitos de outrem".

A principal questão envolvendo o tema decorre do tratamento constitucional dispensado à reparação civil dos acidentes do trabalho, uma vez que, da dicção da parte final do inciso XXVIII do artigo $7^{\circ}$ da Constituição Federal, a culpa lato sensu insinua-se como regra geral exclusiva.

Com o estudo da evolução da responsabilidade civil, verificou-se que a idéia de reparação de danos está visceralmente ligada à ideologia vigente no momento de sua aplicação, sempre refletindo o grau de maturidade dos respectivos grupos sociais, podendo-se observar, em cada momento histórico, avanços em relação aos anteriores, tendo sido constatado que a responsabilidade civil, informada pelo princípio da equivalência, constitui um dos principais mecanismos de restauração do equilíbrio social, confundindo-se com a própria noção de Direito.

De fato, da idéia de reparação de danos restrita a uma reação do ofendido, sem regras, sem sistema e sem proporcionalidade, até a adoção da teoria do risco, houve vertiginosa evolução da responsabilidade civil, sempre impulsionada por ideais superiores de moral e de justiça, com claro intuito de promover a humanização das relações intersubjetivas, mediante a ampliação do seu campo de aplicação.

É nesse contexto que a responsabilidade civil, nascida sob a égide da culpa, evoluiu, mediante a objetivação de sua base, para abarcar as atividades de risco. 
Porém, a inaptidão da culpa para imputar a responsabilidade pelos novos tipos de danos que advieram do progresso da sociedade, especialmente aqueles decorrentes de atividades lícitas não tipificadas em lei, levou à criação de novas teorias, dispensando, em hipóteses legais, a noção de culpa, para assegurar a devida reparação às vítimas.

Aparece, então, no campo dos acidentes do trabalho, a responsabilidade objetiva decorrente do risco profissional, relacionado a um Seguro Social ou a um seguro privado obrigatório, com indenização certa e tarifada. $\mathrm{O}$ nexo de imputação, por esse sistema, não se dá mais entre a conduta e o dano, e sim entre o fato e o dano.

Ao lado da responsabilidade objetiva pelo risco profissional, como mecanismo de manutenção e restauração do equilíbrio social, desenvolve-se a responsabilidade civil do empregador baseada na culpa, admitindo, no entanto, hipóteses legais de responsabilidade objetiva, fundada no risco criado. É a forma encontrada para impor a reparação por acidentes do trabalho decorrentes de atividades normalmente desenvolvidas pelo autor do dano, que apresentam risco especial em relação ao risco geral. No entanto, com o método tipificado, o Poder Judiciário fica restrito às hipóteses legais, mesmo que identifique, no caso concreto, uma nova espécie de atividade que importe risco acentuado para o trabalhador.

A responsabilidade objetiva, colocada, desse modo, sob a forma de cláusula geral, se constatada, no caso concreto, hipótese não tipificada de atividade de risco, ou seja, aquela atividade que encerra um risco especial em relação às demais atividades, abre ao Poder Judiciário efetivas possibilidades de reparar danos não decorrentes de culpa, fazendo incidir o regime especial de imputação. Esse sistema especial de responsabilidade, com conceitos, princípios e regras próprios, revela-se importante instrumento de restabelecimento do equilíbrio social, à disposição do Poder Judiciário.

Em se tratando da responsabilidade civil pelos acidentes do trabalho, a doutrina e a jurisprudência, pela falta de critérios ou referências legais para classificação da atividade que enseja tratamento diferenciado, polarizaram-se em duas correntes: uma que considera o princípio da supremacia da Constituição, para negar a aplicação da responsabilidade objetiva, e outra que, trabalhando com a idéia de conflito de normas constitucionais, com base no princípio do não-retrocesso social, insculpido no caput do artigo $7^{\circ}$ da Constituição Federal, admite o sistema como regra geral e automática da responsabilidade do empregador. Uma terceira corrente, por sua vez, menos radical, 
propugna, com base no moderno constitucionalismo e no princípio da justiça previsto no inciso I do artigo $3^{\circ}$ da Constituição Federal de 1988, a ponderação de princípios: ao modular a força dos dispositivos constitucionais em tensão, reconhece a culpa como regra geral de imputação, admitindo a aplicação da regra exceptiva contemplada na parte final do parágrafo único do artigo 927 do Código Civil de 2002, mediante atividade interpretativa do juiz da causa.

A terceira corrente, desse modo, por ser aquela que harmoniza os direitos, é, sem dúvida, a que extrai maior efetividade dos comandos constitucionais, sem estabelecer qualquer tensão entre eles, e leva em conta, ainda, o processo histórico de ampliação do campo de aplicação da responsabilidade civil, perfeitamente alinhado com os princípios da dignidade da pessoa humana, da livre iniciativa e dos valores sociais do trabalho. Reconhece, assim, a possibilidade de indenização por acidentes do trabalho decorrentes de atividades que, nada obstante lícitas, normalmente oferecem riscos aos direitos de outrem, cabendo ao órgão julgador caracterizar o risco especial caso a caso, mediante decisão fundamentada.

O presente estudo, assim, procurou demonstrar que a regra especial de imputação objetiva é plenamente compatível com o principio constitucional da indenização civil pelos acidentes do trabalho, consistindo em importante instrumento de justiça social, abarcando hipóteses de danos que não eram passíveis de reparação pelo sistema subjetivo, como é o caso de atividades lícitas que causam danos e que não estão tipificadas em lei. 


\section{REFERÊNCIAS BIBLIOGRÁFICAS}

ALONSO OLEA, Manoel; TORTUERO PLAZA, José Luiz. Instituciones de seguridad social. 13. ed. Madrid: Civitas, 1992.

ALTHUSSER, Louis. Ideologia e aparelhos ideológicos de estado (notas para uma investigação). In: ŽIŽEK, Slavoy (Org). Um mapa da ideologia. Rio de Janeiro: Contraponto, 1996.

ALVIM, Agostinho. Da inexecução das obrigações e suas conseqüências. Rio de Janeiro; São Paulo: Ed. Jurídica e Universitária, 1965.

ARAÚJO, Vaneska Donato de. Responsabilidade civil. São Paulo: Ed. Revista dos Tribunais, 2008. v. 5.

AZEVEDO, Álvaro Villaça. Teoria geral das obrigações e responsabilidade civil. 11. ed. São Paulo: Atlas, 2008.

BARROSO, Luís Roberto. Fundamentos teóricos e filosóficos do novo Direito Constitucional brasileiro (pós-modernidade, teoria crítica e pós-positivismo). In:

(Org.). A nova interpretação constitucional: ponderação, direitos fundamentais e relações privadas. 3. ed. rev. Rio de Janeiro: Renovar, 2008.

(Org.). A nova interpretação constitucional: ponderação, direitos fundamentais e relações privadas. 3. ed. rev. Rio de Janeiro: Renovar, 2008.

BELFORT, Fernando José Cunha. A responsabilidade objetiva do empregado nos acidentes de trabalho. São Paulo: LTr, 2010.

BELTRAN, Ari Possidonio. Da responsabilidade subjetiva e objetiva do empregador por acidente do trabalho, ante as disposições do novo Código Civil. Revista do Departamento de Direito do Trabalho e da Seguridade Social, São Paulo, v. 1, n. 1, jan./jun. 2006. 
BIELSA, Rafael. La culpa en los accidentes del trabajo. 2. ed. Buenos Aires: J. Lajouane \& Cia, 1926.

BITBOL, Aida S. Accidentes de trabajo y enfermidades reparables. Buenos Aires: Bibliográfica Omeba, 1964.

BITTAR, Carlos Alberto. Responsabilidade civil nas atividades perigosas. In: CAHALI, Yussef Said (Coord.). Responsabilidade civil: doutrina e jurisprudência. 2. ed. São Paulo: Saraiva, 1988.

BORGES, Ângela. Mercado de trabalho: mais de uma década de precarização. In: DRUCK, Graça; FRANCO, Tânia (Orgs.). A perda da razão social do trabalho: terceirização e precarização. São Paulo: Boitempo, 2007.

CAHALI, Yussef Said (Coord.). Responsabilidade civil: doutrina e jurisprudência. 2. ed. São Paulo: Saraiva, 1988.

CANOTILHO, José Joaquim Gomes. Direito Constitucional e teoria da Constituição. 3. ed. Coimbra: Almedina, 1999.

CAVALIERI FILHO, Sérgio. Programa de responsabilidade civil. 8. ed. São Paulo: Atlas, 2008.

CINTRA, Antonio Carlos de Araújo; GRINOVER, Ada Pellegrini; DINAMARCO, Cândido Rangel. Teoria geral do processo. 20. ed. São Paulo: Malheiros, 2004.

CRETELLA JÚNIOR, José. Curso de direito romano: o direito romano e o direito civil brasileiro. 7. ed. Rio de Janeiro: Forense, 1980.

DELGADO, Maurício Godinho. Curso de direito do trabalho. 5. ed. São Paulo: LTr, 2006.

DIAS, José de Aguiar. Da responsabilidade civil. 10. ed. Rio de Janeiro: Forense, 1995. v. 1.

DINIZ, Maria Helena. Curso de direito civil brasileiro: responsabilidade civil. 24. ed. São Paulo: Saraiva, 2010. v. 7. 
ELDELMAN, Bernard. La légalisation de la classe ouvrière. Paris. Christian Bourgois Editeur, 1978.

FAUSTO, Ruy. Marx: lógica e política. São Paulo: Brasiliense, 1983.

FIÚZA, Ricardo. Novo Código Civil comentado. São Paulo: Saraiva, 2002.

FLÁVIO TARTUCE. Disponível em: <www.flaviotartuce.adv.br>. Acesso em: 05 jan. 2011 .

FRANÇA, R. Limongi. Responsabilidade aquiliana e suas raízes. In: CAHALI, Yussef Said (Coord.). Responsabilidade civil: doutrina e jurisprudência. 2. ed. São Paulo: Saraiva, 1988.

FUNDACENTRO. Disponível em:

<www.fundacentro.gov.br/conteudo.asp?D=SES\&C=662>. Acesso em: 12 dez. 2010.

GAGLIANO, Pablo Stolze; PAMPLONA FILHO, Rodolfo. Novo curso de direito civil: responsabilidade civil. 7. ed. São Paulo: Saraiva, 2009. v. 3.

GODOY, Cláudio Luiz Bueno de. Responsabilidade civil pelo risco da atividade: uma cláusula geral no Código Civil de 2002. 2. ed. São Paulo: Saraiva, 2010.

GUSMÃO, Paulo Dourado. Introdução ao estudo do direito. 42. ed. Rio de Janeiro: Forense, 2010.

HABERMAS, Jürgen. O discurso filosófico da modernidade. São Paulo: Martins Fontes, 2000 .

HIRONAKA, Giselda Maria Fernandes Novaes. Responsabilidade pressuposta. Belo Horizonte: Del Rey, 2005.

HUBERMAN, Leo. História da riqueza do homem. 20. ed. Rio de Janeiro: Zahar Editores, 1985.

JOSSERAND, Louis. De l'esprit des droits et de leur relativité : théorie dite de l'abus des droits. 2. ed. Paris: Dalloz, 1939. 
LAGO JÚNIOR, Antonio. A responsabilidade civil decorrente do acidente de trabalho. In: LEÃO, Adroaldo; PAMPLONA FILHO, Rodolfo Mário Veiga (Coords.). Responsabilidade civil. Rio de Janeiro: Forense, 2001.

LEXML. Disponível em: <http://www.lexml.gov.br>. Acesso em: 15 jul. 2009.

LIMA, Alvino. Culpa e risco. 2. ed. rev. e atual. Pelo Prof. Ovídio Rocha Barros Sandoval. São Paulo: Ed. Revista dos Tribunais, 1998.

LOPEZ, Teresa Ancona. Princípio da precaução e evolução da responsabilidade civil. São Paulo: Quartier Latin, 2010.

LYRA, Afrânio. Responsabilidade civil. 2. ed. São Paulo: Vellenich, 1979.

MARANHÃO, Ney Stany Morais. Responsabilidade civil objetiva pelo risco da atividade: uma perspectiva civil-constitucional. Rio de Janeiro: Forense; São Paulo: Método, 2010.

MARX, Karl. O capital: crítica da economia política. Tradução de Reginaldo Sant'Anna. 25. ed. Rio de Janeiro: Civilização Brasileira, 2008. Livro I.

MATOS, Olgária C.F. A Escola de Frankfurt: luzes e sombras do iluminismo. São Paulo: Moderna, 1993.

MAXIMILIANO, Carlos. Hermenêutica e aplicação do direito. 19. ed. Rio de Janeiro: Forense, 2010.

MELO, Raimundo Simão de. Direito ambiental do trabalho e a saúde do trabalhador: responsabilidades legais, dano material, dano moral, dano estético, indenização pela perda de uma chance, prescrição. 4. ed. São Paulo: LTr, 2010.

MIRANDA, Francisco Cavalcanti Pontes de. Tratado de direito privado. 3. ed. São Paulo: Ed. Revista dos Tribunais, 1984. t. LIII e t. LIV.

MORAES, Alexandre de. Direito constitucional. 26. ed. São Paulo: Atlas, 2010. Direitos humanos fundamentais. 5. ed. São Paulo: Atlas, 2003. 
NERY JÚNIOR, Nelson; NERY, Rosa Maria de Andrade. Código civil comentado. 4. ed. São Paulo: Ed. Revista dos Tribunais, 2006.

NIETZSCHE, Friedrich Wilhelm. Genealogia da moral: uma polêmica. Tradução, notas e posfácio Paulo César de Souza. 8. reimpr. São Paulo: Companhia das Letras, 1998.

PEREIRA, Caio Mário da Silva. Direito civil: alguns aspectos da sua evolução. Rio de Janeiro: Forense, 2001.

. Direito civil: responsabilidade civil. 9. ed. São Paulo: Atlas, 2009.

Direito civil: teoria geral das obrigações e teoria geral dos contratos. São Paulo: Atlas, 2001.

. Instituições de direito civil. 23. ed. Rio de Janeiro: Editora Forense, 2010. v. 1.

. Instituições de direito civil. 13. ed. Rio de Janeiro: Forense, 2009. v. 3.

. Responsabilidade civil. Rio de Janeiro: Forense, 1995.

Responsabilidade civil. Rio de Janeiro: Forense, 1998.

REALE, Miguel. Lições preliminares de direito. 27. ed. São Paulo: Saraiva, 2002.

RIZZARDO, Arnaldo. Responsabilidade civil: Lei $\mathrm{n}^{\mathrm{o}}$ 10.406, 10.01.2002. 3. ed. Rio de Janeiro: Forense, 2007.

RODRIGUES, Silvio. Direito civil: responsabilidade civil. 20. ed. 5. tir. São Paulo: Saraiva, 2003. v. 4.

SAAD, Teresinha Lorena Pohlmann. Responsabilidade civil da empresa nos acidentes do trabalho. São Paulo: LTr, 1993.

SANTOS, Enoque Ribeiro. Responsabilidade objetiva e subjetiva do empregador em face do novo Código Civil. São Paulo: LTr, 2007.

SAVATIER, René. Traité de la responsabilité civile en droit français. Paris: Librairie Générale de Droit e Jurisprudence, 1939. t. 1. 
SILVA, Regina Beatriz Tavares da. In: FIÚZA, Ricardo (Coord.). Novo Código Civil comentado. São Paulo: Saraiva, 2002.

SILVA, De Plácido e. Vocabulário jurídico. 8. ed. Rio de Janeiro: Forense, 1984.

SOUTO MAIOR, Jorge Luiz. Curso de direito do trabalho: a relação de emprego. São Paulo: LTr, 2008. v. 2.

; CORREIA, Marcus Orione Gonçalves. O que é direito social? In: CORREIA, Marcus Orione Gonçalves (Org.). Curso de direito do trabalho: teoria geral do direito do trabalho. São Paulo: LTr, 2007. v. 1.

SÜSSEKIND, Arnaldo; MARANHÃO, Délio; VIANNA, Segadas; TEIXEIRA FILHO, João de Lima. Instituições de direito do trabalho. 16. ed. São Paulo: LTr, 1996. v. 1.

TELLES JR, Goffredo. O direito quântico. 5. ed. São Paulo, Max Limonad, 1980.

TEPEDINO, Gustavo. Crise de fontes normativas e técnica legislativa na parte geral do Código Civil de 2002. In: (Coord.). A parte geral do novo Código Civil: estudos na perspectiva civil-constitucional. 3. ed. rev. Rio de Janeiro: Renovar, 2007.

(Coord.). A parte geral do novo Código Civil: estudos na perspectiva civilconstitucional. 3. ed. rev. Rio de Janeiro: Renovar, 2007.

TOLOMEI, Carlos Young. A noção de ato ilícito e a teoria do risco na perspectiva do novo Código Civil (arts. 186 a 188). In: TEPEDINO, Gustavo (Coord.). A parte geral do novo Código Civil: estudos na perspectiva civil-constitucional. 3. ed. rev. Rio de Janeiro: Renovar, 2007.

TORTORELlO, Jayme Aparecido. Acidentes do trabalho: teoria e prática. 2. ed. São Paulo: Saraiva: 1996.

VENOSA, Sílvio de Salvo. Direito civil: responsabilidade civil. 9. ed. São Paulo: Atlas, 2009.

Direito civil: teoria geral das obrigações e teoria geral dos contratos. São Paulo: Atlas, 2001. 
ŽIŽEK, Slavoj. Como Marx inventou o sintoma. In: (Org.). Um mapa da ideologia. 3. reimpr. Rio de Janeiro: Contraponto, 1996. 